\title{
Ethiopia gender survey: A study in seven regions
}

\author{
Annabel Erulkar \\ Population Council \\ Abebaw Ferede \\ Population Council \\ Worku Ambelu \\ Population Council \\ Woldemariam Girma \\ Population Council \\ Helen Amdemikael
}

See next page for additional authors

Follow this and additional works at: https://knowledgecommons.popcouncil.org/departments_sbsr-pgy

Part of the Demography, Population, and Ecology Commons, Domestic and Intimate Partner Violence Commons, Family, Life Course, and Society Commons, Gender Equity in Education Commons, International Public Health Commons, and the Women's Health Commons How does access to this work benefit you? Let us know!

\section{Recommended Citation}

Erulkar, Annabel, Abebaw Ferede, Worku Ambelu, Woldemariam Girma, Helen Amdemikael, Behailu GebreMedhin, Berhanu Legesse, Ayehualem Tameru, and Messay Teferi. 2010. "Ethiopia gender survey: A study in seven regions," report. Addis Ababa: Population Council. 


\section{Authors}

Annabel Erulkar, Abebaw Ferede, Worku Ambelu, Woldemariam Girma, Helen Amdemikael, Behailu GebreMedhin, Berhanu Legesse, Ayehualem Tameru, and Messay Teferi 


\section{ETHIOPIA GENDER SURVEY A Study In Seven Regions}

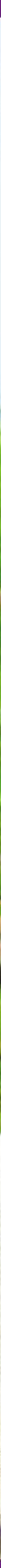





\title{
Ethiopia Gender Survey A Study In Seven Regions
}

\author{
Population Council \\ Annabel S. Erulkar \\ Abebaw Ferede \\ Worku Ambelu \\ Woldemariam Girma \\ UNFPA \\ Helen Amdemikael \\ Behailu GebreMedhin \\ Berhanu Legesse \\ Ayehualem Tameru \\ Messay Teferi
}




\title{
(2) Population Council
}

The Population Council is an international, nonprofit, nongovernmental organization that seeks to improve the wellbeing and reproductive health of current and future generations around the world and to help achieve a humane, equitable, and sustainable balance between people and resources. The Council conducts biomedical, social science, and public health research and helps build research capacities in developing countries. Established in 1952, the Council is governed by an international board of trustees. Its New York headquarters supports a global network of regional and country offices.

(C) 2010 The Population Council, Inc.

\author{
Population Council \\ P.O. 25562, Code 1000 \\ Addis Ababa, ETHIOPIA \\ Tel: (251) (0) 116-631-712/4/6
}

\author{
Population Council \\ One Dag Hammarskjold Plaza \\ New York, NY 10017 USA \\ Tel: (1) 212-339-0500, Fax: (1) 212-755-6052 \\ www.popcouncil.org
}

The United Nations Population Fund is an international development agency that promotes the right of every woman, man and child to enjoy a life of health and equal opportunity. UNFPA supports countries in using population data for policies and programmes to reduce poverty and to ensure that every pregnancy is wanted, every birth is safe, every young person is free of HIV/AIDS, and every girls and women is treated with dignity and respect.

\author{
Annabel S. Erulkar, MSc, PhD is Country Director of the Population Council's Country Office in Ethiopia. \\ Abebaw Ferede, MSc, is Senior Program Officer for the Population Council in Addis Ababa, Ethiopia. \\ Worku Ambelu, MSc, is Research Coordinator for the Population Council in Addis Ababa, Ethiopia. \\ Woldemariam Girma, MSc, is Senior Program Officer for the Population Council in Addis Ababa, Ethiopia. \\ Helen Amdemikael, MA, is Assistant Representative for UNFPA, Ethiopia. \\ Behailu GebreMedhin, MSc, is is M\&E National Program Officer for UNFPA, Ethiopia. \\ Berhanu Legesse, MPH, is National Program Officer for UNFPA, Ethiopia. \\ Ayehualem Tameru, MSc is National Program Officer for UNFPA, Ethiopia. \\ Messay Teferi, MSc, is M\&E National Program Officer for UNFPA, Ethiopia.
}




\section{Table of Contents}

Chapter One

Chapter Two

Chapter THREE

ChAPTER Four

Chapter Five

Chapter Six

Chapter Seven

Chapter Eight

Chapter Nine
INTRODUCTION. $\ldots 1$

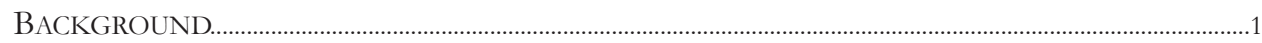

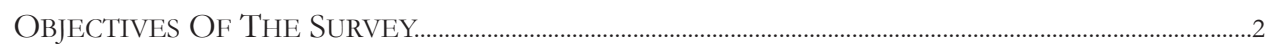

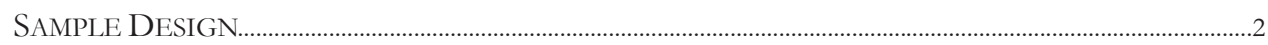

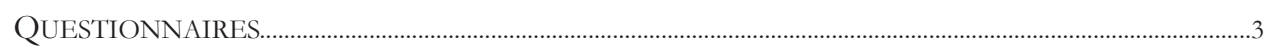

DATA COLLECTION........................................................................................................................................

RESPONSE RATES \& SAMPLE CHARACTERISTICS..................................................................................

HOUSEHOLDS CHARACTERISTICS

HOUSEHOLD COMPOSITION.................................................................................................................................

HOUSEHOLD POSSESSIONS \& AMENITIES...............................................................................................

MIGRATION

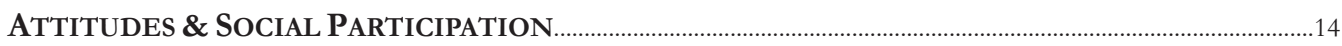

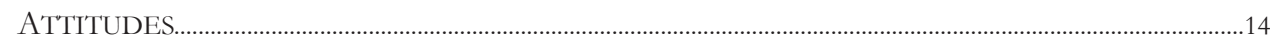

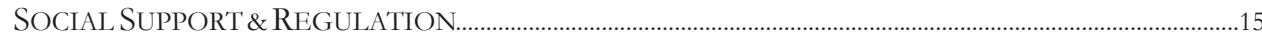

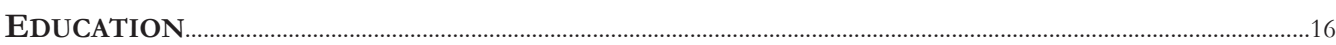

SCHOOL ATTENDANCE...………………………………………………………………………………………………16

EDUCATIONAL ATTAINMENT_...............................................................................................................17

LIVELIHOODS …………………………………………………………………………………………………………………

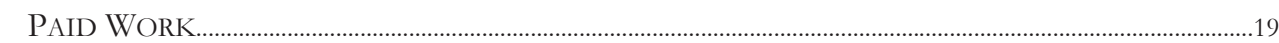

SKILLS TRAINING \& MICRO-CREDIT......................................................................................................2

SAVINGS \& EXPENDITURE ...................................................................................................................... 23

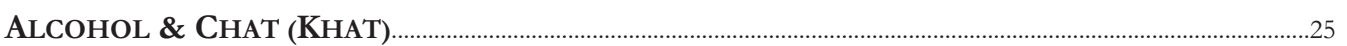

ALCOHOL

CHAT / KHAT

FEMALE GENITAL MUTILATION/CUTTING ……………………………………………………………………….....29

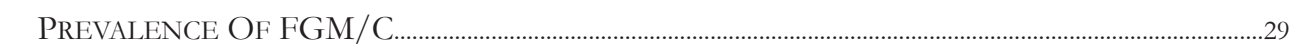

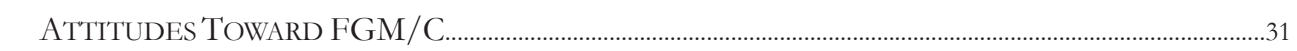

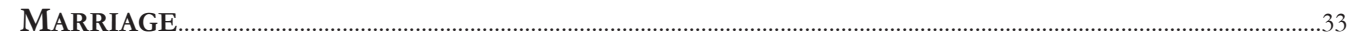

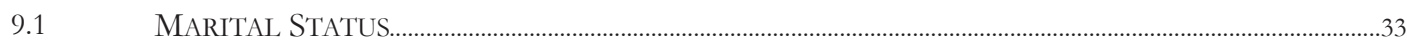

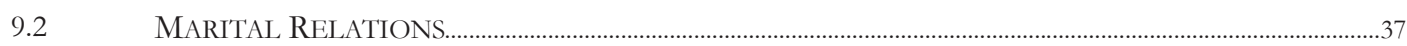


Chapter Eleven

SAFE MOTHERHOOD.

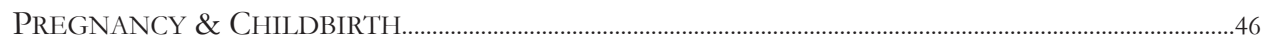

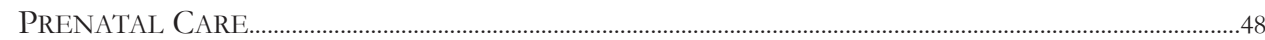

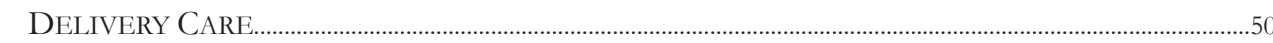

HIV AND AIDS KNOWLEDGE \& PRACTICES.................................................................................................52

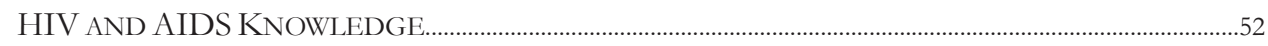

STIGMA\&DISCRIMINATION ……………………………………………………………………………………....54

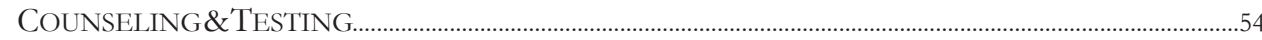

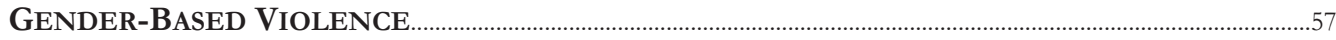

ATTITUDESTOWARD GENDER-BASED VIOLENCE......................................................................................57

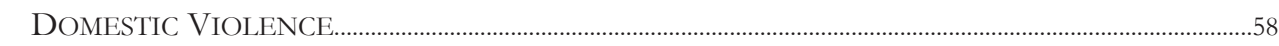

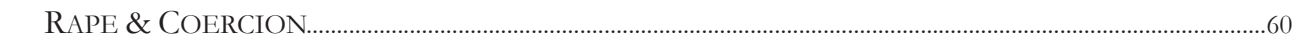

INFORMATION ON GENDER-BASED VIOLENCE_....................................................................................61

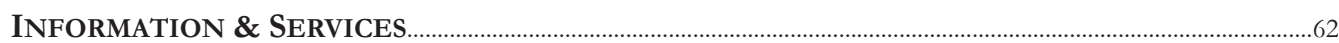

SOURCES OF INFORMATION.............................................................................................................62

PREFERENCE FOR SERVICES...................................................................................................................................63

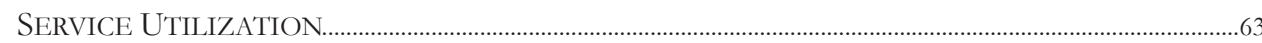

Chapter FifteEn ReCOMMENDATIONS For Programs

Appendix A

APPENDIX B
SAMPLE INFORMATION . .67

DATA Collection STAFF 


\section{TABLeS}

Chapter One

Table 1.1

Table 1.2

\section{Chapter Two}

Table 2.1

Table 2.2

Table 2.3

Table 2.4

Table 2.5

Table 2.6

\section{Chapter Three}

Table 3.1

Table 3.2

\section{CHAPTER Four}

Table 4.1

Table 4.2

Table 4.3

Table 4.4

\section{Chapter Five}

Table 5.1

Table 5.2

Table 5.3

Table 5.4

\section{Chapter SiX}

Table 6.1

Table 6.2

Table 6.3

Table 6.4

Table 6.5

Table 6.6

Table 6.7

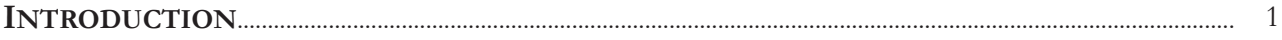

Responseratesof women's survey.............................................................................................................. $\quad 5$

Percentdistribution of thefemalesample, by selected characteristics....................................................... 6

HOUSEHOLDSCHARACTERISTICS

Household composition: Household heads and number of usual household members, by type of place of residence

Householdcomposition:Percentageof respondents residingwith familyandnon-familymembers, by category of co-resident and type of place of residence.......................................................................... 7

Household composition: Percentage of respondents owning or renting their place of residence, by type of place of residence........................................................................................................................

Household drinkingwater: Percentof households bysourceof water, timeto source, perceived safety, andaccess, by type of place of residence........

Household sanitation facilities and possessions: Percent of households by type of toilet/latrine and possessing various household effects and assets, by type of place of residence.................................... 10

Individual possessions: Individualownership of items, by type of place of residence............................ 11



Migration:Percentof womenwhoaremigranttothearea, byselected characteristics................................ 12

Migration: Reasons for migration, age at migration and co-migrants, by type of place of residence..... 13

SOCIALSUPPORT \& REGULATION..

Attitudes: Inequitable gender attitudes among women aged 15 to 49, by type of place of residence...... 14

Attitudes: Negative self perceptions among women aged 15 to 49, by type of place of residence........... 15

Social participation: Percentage of women aged 15 to 49 needing permission before engaging in activities, by activity and type of place of residence

Social support:Percentage of womenaged 15 to 49 reportingsources of supportin the community, by support and type of place of residence...

\section{EDUCATION}

Education:Percentof womenaged15-49 whohaveeverbeentoschoolandreasonsfornon-attendance, by type of place of residence and selected characteristics.

Education: Age at school entry, age at school leaving, and reasons for leaving school, by type of place of residence............................................................................................................................... 17

Education: Literacy and number of years of schooling attained, by type of place of residence 18

Educational attainment: Mean years of schooling attained by type of place of residence, age group and region..

\section{LIVELIHOODS.}

Livelihoods: Percent of women who haveeverworked forpay, byselected characteristics.

Livelihoods: Ageatfirstwork, hoursdevoted topaidwork, typeof workandearningsfrompaidwork, by typeof place of residence..

Livelihoods: Mean earnings and hours worked in the last week, by type of work............................ 21

Livelihoods: Vocational and entrepreneurship training, bytype of place of residence............................ 22

Livelihoods: Experiencewithmicro-credit, bytypeof placeof residence................................................... 23

Livelihoods: Percentage of women aged 15 to 49 having personal cash savings, by type of place of residence

Livelihoods: Mean monthly household expenditure on basic items, by type of place of residence and number of household members (in Ethiopian Birr)... 
Alcohol: Percentage of women drinkers aged 15 to 49 who drank alcohol by frequency of alcohol consumptionin thelastmonth, by typeof place of residence

Table 7.4 Chat: Percentage of female chat users who chewed in the last month, and frequency of chat consumption, bytype of placeof residenceand selected characteristics...

CHAPTER EIGHT

Table 8.1

Table 8.2

Table 8.3

Table 8.4

Table 8.5

\section{ChAPTER Nine}

Table 9.1

Table 9.2

Table 9.3

Table 9.4

Table 9.5

\section{Chapter Ten}

Table 10.1

Table 10.2

Table 10.3

Table 10.4

Table 10.5

Table 10.6

Table 10.7

Table 10.8

Table 10.9

Table 10.10

\section{Chapter Eleven}

Table 11.1

Table 11.2
Female Genital Mutilation/Cutting

Femalegenitalmutilation/cutting:Percentage of womenaged 15 to 49 whoarecircumcised, by typeof circumcision and selected characteristics.

Femalegenitalmutilation/cutting:AgeatFGM/C,decision-maker,andprofile of circumciser,bytype

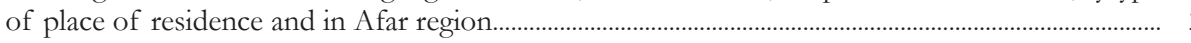
Femalegenital mutilation/cutting: Percentage of women supportingoropposing theirownFGM/C and reasons, by type of place of residence and in Afar region..

Female genital mutilation/cutting: Personal opinions about FGM/C, by type of place of residence, and in Afar region.

Femalegenitalmutilation/cutting:Futureintentions regardingFGM/Candexposuretomessages, by typeof place of residenceandinAfarregion.

MARRIAGE

Marriage:Currentmaritalstatus of womenaged15to49, byselectedcharacteristics................................... 34

Marriage:Percentage of respondents marriedbyage 15 and 18 , amongrespondentsaged 18 andabove, byselected characteristics..

Marriage: Age at firstmarriage and context of marriage, by type of place of residence............................ 36 Marriage: Timing of sexual initiation and marital sexual relations, by type of place of residence........ 37 Marriage: Discussion and decision-making within marriage, by topic and type of place of residence...

Family planning knowledge: Percentage of all women, currently married women and never married sexually active women knowing family planning methods, by type of place of residence and method..

Family planning use: Percentage of all sexually experienced women, ${ }^{1}$ currently married women and never married sexually active women using family planning methods, by type of place of residence and method.

Family planning use: Current use of family planning among currently married women, by selected characteristics

Source of familyplanning: Mostrecentsource of familyplanning, bymethod..

Source of family planning: Travel time, waiting time, and payment for family planning services among current users, by type of place of residence.

Family planning providers: Perception of family planning service providers among current users, by type of place of residence.

Family planning intentions: Percentage of currently married women not using family planning who intend touseamethodin thefuture, bynumberof children.

Family planning non-use: Percentage of currently married women not intending to use a method, by reason for non-use.

Condoms: Percentage of women with correct information about condoms and accepting attitudes toward condoms, by type of place of residence.

Condoms: Percentageof currentlymarriedand sexuallyactive, unmarriedwomenwhoused condoms at last sex, by source of condoms and type of place of residence..

\section{SAFE MOTHERHOOD}

Parenthood: Women's attitudes to childbirth and maternal mortality, by type of place of residence childbirth (among women with partners) and opinion of all respondents on health facilities, by type of place of residence. 
Table 11.3

Table 11.4

Table 11.5

Table 11.6

Table 11.7

Table 11.8

\section{Chapter Twelve}

Table 12.1

Table 12.2

Table 12.3

Table 12.4

Table 12.5

Table 12.6

Table 12.7

Table 12.8

\section{Chapter THIRTEen}

Table 13.1

Table 13.2

Table 13.3

Table 13.4

Table 13.5

Table 13.6

Table 13.7

\section{Chapter Fourteen INFOrmation \& SERVICES}

Table 14.1

Table 14.2

Table 14.3

Table 14.4

\section{APPENDIX}

Table A1 selected characteristics

characteristics type of place of residence. residence by selected characteristics.. type of place of residence.... type of place of residence.. of residence

Parenthood: Percentage of women who have ever given birth, by type of place of residence and

Prenatal care: Percentage of women who received prenatal care and reasons fornotreceiving prenatal care, by type of place of residence and selected characteristics..

care: Percentage of women who received prenatal care, by source of care and selected

Delivery:Location of firstbirth, by type of place of residence...................................................................... 50

Delivery: Location of first birth, by selected characteristics...................................................................... 51

Delivery: Assistanceduring firstbirth, bytypeof place of residence.................................................... 51

HIV and AIDS: Percent distribution of women who have heard of HIV/AIDS, by type of place of residence and selected characteristics..

HIV and AIDS: Knowledge of modes of HIV transmission, by method of transmission and

HIV and AIDS: Knowledge and misconceptions about HIV and AIDS, by type of place of

HIV and AIDS: Accepting attitudes toward people living with HIV and AIDS, by type of place of residence (percent agreeing or disagreeing with the statements)

HIV and AIDS: Percentage of women aged 15 to 49 who ever been counseled and tested for HIV,

HIV and AIDS: Main reasons for having counseling and testing for HIV, by type of place of residence........................................................................................................................................................ 55

HIV and AIDS: Main reasons for not receiving counseling and testing for HIV, among sexually experienced women, by type of place of residence...

HIV and AIDS: Percent distribution of ever married women aged 15 to 49 who have had marital counseling and testing, context of testing, and perception of marital risk...

Gender-based violence: Percent distribution of girls and women holding inequitable or accepting views of gender relations and violence, by type of place of residence and age group...

Gender-based violence: Percent distribution of ever married women experiencing controlling behavior by spouses, by type of place of residence, age group, and marital status...

Genderbasedviolence: Percent distribution of evermarriedwomenexperiencingdomestic violence, by type of place of residence, age group, and marital status.

Gender-based violence: Percent distribution of victims of violence (in last three months) who think they deserved being beaten or told someone about it, by type of place of residence.

Rapeand coercion: Percentage of sexuallyexperiencewomenaged 15 to 49 whoexperienced forcedor coerced first sex, by type of place of residence..........

Rape: Percent distribution of victims of rape who told someone about it and sought assistance, by

Gender-basedviolence: Percentageof women15to49receivinginformationonGBVinthelastyear,by source of information and type of place of residence.

Information: Percentage of women 15 to 49 receivinginformation on pregnancyand familyplanning, bysource of informationand type of place of residence.

Services: Percentage of women 15 to 49 citing service characteristics as 'very important' in choice of service, bycharacteristicand type of place of residence..

Services: Percentage of women 15 to 49 frequenting services in the last year, by type of service and

Services: Mean travel time (in minutes, one way) to services, by type of service and type of place 


\section{ACKNowledgments}

Many organizations and individuals contributed to the "Ethiopia Gender Survey: A Study in Seven Regions." The authors gratefully acknowledge the Ethiopia Ministry of Finance and Economic Development (MOFED) at Federal, Regional, and District/Woreda levels for their support and facilitation. We thank kebele officials in the study sites for assistance provided to field staff, as well as Bureaus of Youth and Sport and youth center heads for support and facilitation.

In addition, we would like to extend a special thanks to the Central Statistical Agency, for their support, and guidance, including provision of enumeration area maps. In particular, we acknowledge the contribution made by Ato Biratu Yigezu for his technical support, advice on sample and research design, and numerous other technical insights. Ato Lemi Negeri was the national coordinator for the survey and we acknowledge his commitment and dedication to this study. Dr. Tekle Ab Mekbib provided facilitation and support throughout the course of the study. Mitike Molla and Yamrot Girma coordinated the study in Addis Ababa and SNNPR. Lucy N'gang'a of the Population Council Kenya office designed the data entry screen and Fikerte Berihum assisted with data management and cleaning. We thank all the interviewers, supervisors, coordinators, field guides, and data entry clerks for their hard work and dedication to this study. Ane Etxebarria and Dr. Wendy Baldwin provided useful comments on earlier versions of the report.

UNFPA and DFID provided funding for this study. UNFPA's support came from grants from the Norwegian Ministry of Foreign Affairs which supports the "UNFPA-UNICEF Joint Program on Rights Based Approaches to Adolescent and Youth Development in Ethiopia," and the Spanish MGD Fund which supports the UNFPA-WFP program "Leave No Woman Behind." Finally, we would like to thank all the respondents from seven regions who took part in the study, for sharing their experiences, thoughts and ideas.

\section{List Of Acronyms}

$\begin{array}{ll}\text { ARH } & \text { Adolescent reproductive health } \\ \text { CBRHA } & \text { Community based reproductive health agent } \\ \text { CSW } & \text { Commercial sex worker } \\ \text { DHS } & \text { Demographic and Health Survey } \\ \text { EA } & \text { Enumeration area } \\ \text { EDHS } & \text { Ethiopia Demographic and Health Survey } \\ \text { FGM/C } & \text { Female genital mutilation/cutting } \\ \text { FLE } & \text { Family life education } \\ \text { GBV } & \text { Gender based violence } \\ \text { GDI } & \text { Gender development index } \\ \text { HEW } & \text { Health extension worker } \\ \text { HTP } & \text { Harmful traditional practices } \\ \text { MFI } & \text { Micro-finance institution } \\ \text { NGO } & \text { Nongovernmental organizations } \\ \text { PLWHA } & \text { People living with HIV/AIDS } \\ \text { RH } & \text { Reproductive health } \\ \text { SNNPR } & \text { Southern Nations, Nationalities and Peoples' Region } \\ \text { SRH } & \text { Sexual and reproductive health } \\ \text { UNDP } & \text { United Nations Development Programme } \\ \text { UNFPA } & \text { United National Fund for Population Activities } \\ \text { UNICEF } & \text { United Nations Children's Fund } \\ \text { VAW } & \text { Violence against women } \\ \text { VCT } & \text { Voluntary counseling and testing } \\ \text { WFP } & \text { World Food Programme } \\ & \end{array}$




\section{Executive Summary}

"Ethiopia Gender Survey: A Study in Seven Regions" is a population-based survey taking place in 2009 in urban and rural areas of seven regions: Addis Ababa, Afar, Amhara, Beneshangul-Gumuz, Oromiya, Southern Nations, Nationalities and Peoples' Region (SNNPR), and Tigray. Over 8,000 women aged 15 to 49 were interviewed.

\section{RESEARCH DESIGN}

As the study was intended as a baseline for planned interventions, the sample was designed to be representative of the intervention and comparison districts/woredas identified for the new projects. In each region, between three to six districts/woredas were selected. In all, 31 districts/woredas were selected for the study. Within selected districts/woredas, 252 enumeration areas (EAs) were selected, or 36 EAs per region. In all, 262 interviewers took part in the survey.

All EAs selected for the study first underwent a census of all households, or 'household listing,' in order to establish a sampling frame for the locations. Selection of respondents was random with only one respondent selected in each household. Only female interviewers conducted the interview of females. Informed consent was obtained from respondents and their parents or guardians if they were below age 18. Data was entered at Population Council offices and, ultimately, weighted in order to adjust for unequal probabilities of selection. The survey achieved a 98 percent response rate.

\section{RESULTS}

The survey revealed considerable differences in the situations of rural and urban women, as well as women in different regions of the country.

Household composition: Sixteen percent of respondents were heads of their households with considerably more urban females heading households ( 24 percent) compared to their rural counterparts (16 percent). Over 60 percent of women co-resided with their own children and a spouse; 30 percent lived with parents and siblings. The composition of households tended to be more diversified in urban settings, compared to rural areas.

Migration: Thirty-nine percent of respondents were not native to their place of residence and had moved there from another location. More urban women (56 percent) were migrants compared to rural women (27 percent). While the majority of rural female migrants moved for reasons related to marriage (75 percent), urban women moved for a multiplicity of reasons including work (28 percent) and schooling (21 percent).

Social support \& regulation: A considerable proportion of women held gender inequitable attitudes on issues related to domestic work, boys' and girls' scholastic abilities, and control of men over women, among others. Rural women tended to hold more conservative gender attitudes then urban women. Over 75 percent of respondents reported regulation of their movements, such as needing permission before leaving the house, visiting a friend, or attending a club meeting. Only about half of the respondents reported having support in times of need such as in the case of a medical emergency (57 percent), in the case of violence in the home (56 percent), and if one needed a place to sleep temporarily (47 percent). Rural women reported somewhat higher levels of support than did urban women.

Education: There were significant urban-rural differentials in educational participation with 75 percent of urban women and 31 percent of rural women having ever attended school. The likelihood that one had 
attended school decreased with age, reflecting recent expansion of schooling in the country. Main reasons cited for not attending school were family disapproval (52 percent), marriage (22 percent) and poverty (20 percent). Among those who attended school, mean age at school entry was late (mean 9 years) with rural respondents starting school later (mean 10 years). Marriage was the most common reason for leaving school among 28 percent of respondents, followed by inability to afford schooling costs ( 23 percent), and domestic duties (22 percent).

Livelihoods: Thirty-six percent of women have ever engaged in paid work (45 percent of rural women and 30 percent of rural women). The most common forms of paid work were petty trader (22 percent), farming (17 percent), and domestic worker (13 percent). Among urban women, 23 percent were working as domestic worker, which ranked among the lowest paid jobs mentioned. Four percent of women had received skills/ vocational training, however, 64 percent had not put the training to use. The main reason given for not putting the skills to use was the inability to find a job (68 percent). Six percent of respondents had received a micro-loan and 81 percent reported the loan improved the economic situation of the household.

Alcohol \& chat/khat: The majority of women (69 percent) report never consuming alcohol. Urban women are more likely to abstain from alcohol (88 percent) compared to rural women (69 percent). Only 3 percent of women had ever tried chat/khat, with significant regional variability in chat use. Sixteen percent of Afar women and 6 percent of Ormiya women had tried it. Among women who had tried the substance, 71 percent had also consumed it in the month prior to survey.

Female genital mutilation/cutting: Seventy-percent of women in the sample were circumcised. The practice seems to be declining as successive cohorts of women report lower levels of circumcision. Regions with the highest rates of circumcision are Afar (95 percent), SNNPR (91 percent), and Oromiya ( 89 percent). Over half (57 percent) of the circumcised women in the sample oppose the fact that they were circumcised ( 85 percent of urban women; 45 percent of rural women). Only 23 percent of respondents believe the practice should continue. However, in Afar Region, 42 percent support its continuation.

Marriage: Seventy-one percent of respondents had ever been married, with 9 percent being divorced/ separated and 4 percent widowed. While legal age at marriage in Ethiopia is 18 for both boys and girls, early marriage was still common. Twenty-five percent of respondents were married by age 15, with the highest proportions of girls married by their $15^{\text {th }}$ birthday in Amhara (52 percent) and Beneshangul Gumuz (31 percent). The majority of marriages (70 percent) were arranged with 45 percent of urban women and 82 percent of rural women experiencing arranged marriage. Married women were, on average, 7 years younger than their spouses, with spousal age differences increasing when women are married at younger ages. Respondents reported relatively low levels of communication with their husbands on topics such as domestic duties, maternal and child health (MCH) services and HIV/AIDS.

Family planning: There was high awareness of family planning (FP) methods, with 94 percent of respondents knowing of at least one method, mainly injectables ( 92 percent) and pills ( 90 percent). Overall, 50 percent of women who were currently married and 63 percent of never married sexually active women had ever used an FP method. Current use of FP was 39 percent among currently married women and 44 percent among never married sexually active women, representing a marked increase in family planning use over previous years. Among urban married women, 56 percent were currently using a method. The public sector was the main source of family planning, with 60 percent of women obtaining methods from health centers or health posts and 11 percent from health extension workers. Among non-users not intending to use a method, the main reasons given were desire for more children (30 percent), fear of side effects ( 15 percent), religious reasons (12 percent) or partner opposition (11 percent).

Safe motherhood: Sixty-three percent of respondents had ever given birth (52 percent of urban women and 71 percent of rural women). There were significant urban-rural differentials in maternity care and the location and assistance during delivery. While 66 percent of urban women received prenatal care, only 25 percent of rural women received it. Among women not receiving care, there was a widespread perception 
that prenatal care was not needed (36 percent) and that such care was not practiced in their communities (24 percent). Eighty percent of women delivered in the home (50 percent of urban women and 95 percent of rural women). Home births were most common among the youngest mothers aged below 20 (88 percent), and among those with no education (92 percent).

HIV and AIDS: Awareness of HIV and AIDS was extremely high, as well as knowledge that HIV is transmitted through intercourse. However, a considerable proportion of respondents held misconceptions regarding HIV, including that most people get HIV contract HIV through accidents with sharp objects (58 percent) and that one can get HIV from eating utensils (52 percent). Thirty-seven percent of respondents had received counseling and testing, mainly out of curiosity (67 percent), in the context of prenatal care (18 percent) or before marriage (17 percent). Among married women, nearly one quarter of partners have both tested (23 percent), mainly in couples' counseling and testing (63 percent), as opposed to testing alone (37 percent).

Gender-based violence: There were high levels of acceptance of gender based violence (GBV), particularly among rural women. Among ever-married women, 10 percent had experienced physical violence from their husbands and 2 percent had been beaten in the three months prior to survey. While 26 percent of wives reported that their husbands had been drinking during the last incident of domestic violence, one in ten female victims thought they deserved the beating. A considerable percentage of women reported that their first sex was a result of rape (12 percent of urban respondents; 19 percent of rural respondents). Most forced sex was at the hands of intimate partners, especially husbands, boyfriends and fiancés. Fifteen percent of women who experience forced first sex blamed themselves for what happened and very few sought medical, legal or psychological assistance, in particular rural women. One in five women had heard a GBV message in the last year, especially from radio and television. Sources of GBV information differed significantly by urban-rural residence.

Information \& services: Husbands and female friends were important sources of information on issues such as pregnancy and family planning, with roughly half of all respondents receiving information from their husbands and approximately four out of ten receiving information from friends. Teachers and health extension workers were also frequently cited as sources of reproductive health information. Urban respondents were considerably more likely to have visited health facilities in the last year compared to rural respondents. Limited use of health facilities by rural women may be associated with significant travel time to services. On average, it took rural women over 1 hour to travel to a health center and nearly 2 hours to travel to a hospital. In contrast, religious services were accessed by a majority of respondents ( 87 percent), with services relatively more accessible (less than $1 / 2$ travel time to a religious service).

Recommendations for programs: "Ethiopia Gender Survey: A Study in Seven Regions" highlights significant differences between women residing in urban and rural areas of Ethiopia and suggests programmatic directions to better serve Ethiopian girls and women. Based on the study findings, recommendations include:

- Address inequitable gender attitudes;

- Expand school opportunities, especially in rural areas, and address practices that limit girls' participation;

- Expand livelihoods opportunities and move beyond skills training to include internship opportunities and job placement;

- Intensify programs combating female genital mutilation/cutting (FGM/C) in areas of high prevalence;

- Expand programs to delay marriage and promote increased communication and cooperation within marriage, including strategies to reduce domestic violence;

- Expand the mix of family planning methods available and promote safe motherhood initiatives, especially in rural areas;

- Increase attention to gender based violence, expanding programs to prevent GBV, support victims, and enforce laws, and including initiatives to change gender norms of men and boys; and

- Expand resources and services in rural areas, as well as programs delivered through religious institutions. 


\section{Chapter One: Introduction}

\subsection{BACKGROUND}

Ethiopia is the second most populous country in sub-Saharan Africa with an estimated population of 74 million people. Eighty-four percent of the population resides in rural areas. Ethiopian women, adolescents and youth are disadvantaged. Women's status is extremely low, with their situation reflected in extremely poor economic, social and health indicators.

\section{The status of women in Ethiopia}

Girls and women in Ethiopia are at a distinct disadvantage compared to boys and men on a range of issues such as education, health, and basic human rights. Ethiopia is ranked $129^{\text {th }}$ out 136 countries on genderrelated development index (GDI). ${ }^{1,2}$ While levels of educational attainment are low, the disparities between men and women are significant. According to the 2005 Ethiopia Demographic and Health Survey (EDHS), two thirds of Ethiopian women and girls have no education, compared to about half of men. ${ }^{3}$ Disparities in educational attendance and attainment are particularly apparent at the higher levels, including secondary education and university.

The acceptance of violence against women (VAW) and violence in the home is high in Ethiopia. The 2005 EDHS found that 81 percent of women agreed that there are circumstances in which women should be beaten. ${ }^{4}$ While there is high acceptance of violence, few studies in Ethiopia have measured actual levels of sexual or domestic violence.

The disadvantage and vulnerability of women frequently has roots during adolescence, and Ethiopian girls face particular challenges including limited access to schooling, early and unwanted marriage, lack of parental presence, unsafe and exploitive work roles, and coercive sexual relations. Studies have highlighted that sexual initiation and childbearing begins early in Ethiopia, with young people often having little knowledge and limited access to reproductive health $(\mathrm{RH})$ services. $^{5}$ Among girls in Ethiopia, most sexual initiation occurs within the context of marriage. ${ }^{6}$ High rates of early marriage take place in many regions, including marriage during girls' early adolescence, by their $15^{\text {th }}$ birthday. These early marriages include early sexual initiation and early first birth. Further, in some regions, marriage by abduction is practiced, where an unmarried girl is forcefully taken, often followed by rape by her future husband or gang rape by her husband and friends.

\section{Reproductive health}

Reproductive health (RH) indicators in Ethiopia reflect the disadvantage of adolescent girls and women. The 2005 EDHS estimated contraceptive prevalence at only 14.7, (47 percent in urban areas versus 11 percent in rural areas). The country has one of the lowest rates of attended births in the world, with 94 percent of women delivering at home. The maternal mortality ratio is seven deaths per 1,000 live births (i.e. 673 per 100,000 live births), one of the highest in the region. ${ }^{7}$ In addition, some of these unattended home births result in fistula, which remains a problem in Ethiopia.

\footnotetext{
${ }^{1}$ GDI is a composite index measuring average achievement in three basic dimensions: health, education, and standard of living, adjusted to account for inequalities between men and women.

${ }^{2}$ United Nations Development Program (UNDP), Human Development Report: 2007/2008, New York: UNDP.

Central Statistical Agency (CSA) \& ORC Macro. 2006. Ethiopia Demographic \& Health Survey 2005, Addis Ababa, Ethiopia \& Calverton MD.

${ }^{4}$ Ibid.

${ }^{5}$ Govindasamy P, Kidanu A, Bantayerga H. 2002. "Youth Reproductive Health in Ethiopia," Addis Ababa Ethiopia and Calverton MD: ORC Macro and Miz-Hasab Research Center,

November.

"Govindasamy et. al, Ibid, Erulkar AS, Mekbib T, Simie N, Gulema T. 2004. "The experience of adolescence in rural Ambara region Ethiopia" Accra: Population Council.

CSA and Macro, op. cit.
} 
Female genital mutilation/cutting (FGM/C) is very common in Ethiopia. Estimates from 2005 DHS suggest that, nationally, 74 percent of women have undergone FGM/C. In the Somali region, 84 percent of women have undergone FGM/C, mainly infibulations, the most severe form of FGM/C.

\section{The HIV epidemic in Ethiopia}

In sub-Saharan Africa, girls and women are disproportionately affected by the HIV epidemic; 59 percent of all infections on the continent are among females. ${ }^{8}$ It is estimated ${ }^{9}$ that 2.1 percent of the large population of Ethiopia is HIV positive, with the epidemic concentrated among women and in urban areas. The HIV prevalence in urban areas of Ethiopia is an estimated 7.7 percent, with 9.3 percent prevalence among women and 6.2 percent prevalence among men, a female to male ratio of 1.5 to $1 .{ }^{10}$ Moreover, the younger the age group, the greater the gender imbalance in rates of HIV infection, with far greater rates among young women compared to young men. Formerly married women have among the highest rates of infection, with 8.1 percent of divorced/separated women and 5.6 percent of widows living with HIV. ${ }^{11}$

\subsection{OBJECTIVES OF THE SURVEY}

This research contributes to up-to-date and nuanced understanding of HIV behavior, gender issues and reproductive health among women in seven regions of Ethiopia. Specific objectives are:

- To document knowledge, attitudes and practices among Ethiopian girls and women with respect to sexual and reproductive health (SRH), HIV and gender based violence (GBV);

- To determine the level of access to and utilization of quality SRH, HIV prevention and prevention of GBV services;

- To assess access to health services and other social services, as well as patterns of utilization;

- To measure knowledge attitudes and practices related to violence against women, such as domestic violence, coercion and rape, FGM/C and including patterns of violence experienced by girls and women in different circumstances; and

- To assess levels of FGM/C and practices among groups practicing FGM/C.

The information will serve as the baseline survey for four new initiatives in Ethiopia related to adolescent health and development, gender-based violence, women's empowerment, and female genital cutting/ mutilation. Ultimately, the baseline estimates will be used to measure changes associated with the projects, implemented by UNFPA, UNICEF, World Food Programme (WFP) and other partners in Ethiopia.

\subsection{SAMPLE DESIGN}

The "Ethiopia Gender Survey: A Study in Seven Regions" was designed as a baseline survey for four intervention projects in Ethiopia. The survey took place in the seven regions in which the interventions were intended to be implemented: Addis Ababa, Afar, Amhara, Beneshangul Gumuz, Oromiya, Southern Nations, Nationalities and Peoples (SNNP), and Tigray. Somali and Gambela Regions were not included in the study as interventions were not planned for these locations.

The sample was designed to be representative of the intervention and comparison districts/woredas identified for the four new initiatives on adolescent health and development, gender based violence, women's empowerment, and female genital cutting/mutilation. For the women's survey, a sample of 5,040 women aged 25 to 49 was selected, 720 in each region. In addition, this report includes analysis of the young women sampled in the youth survey, aged 15 to 24 . Including the entire age range 15 to 49 for the analysis allows us to be consistent with the age range in Demographic and Health surveys.

\footnotetext{
${ }^{8}$ UNAIDS/Global Coal. on Women \& AIDS (2006) "Keeping the Promise: Agenda for Action on Women \& AIDS," Geneva: UNAIDS. ${ }^{9}$ Ministry of Health (MOH) \& Federal HIV/AIDS Prev. \& Control Office (HAPCO), "Single Point HIV Prevalence Estimate," June, 2007.

${ }^{11}$ Measure DHS / CSA (2006) “2005 Ethiopia Demographic \& Health Survey: HIV Prevalence,” Fact sheet, Calverton MD, Addis Ababa.
} 
The sample for the study was stratified and clustered. Within the study regions, districts/woredas were listed as to whether they had been identified for the planned interventions or could serve as comparison sites. The ratio of intervention to control respondents was 2 to 1 . In each region, between three to six districts/woredas were selected, with a ratio of roughly two intervention districts selected for every one comparison district. The number of districts selected in a particular region was determined by the populations in the districts; if districts had small populations, additional districts were selected to compensate. In all, 31 districts/woredas were selected for the study. Within selected districts/woredas, 252 enumeration areas (EAs) were selected, or 36 EAs per region (see Appendix Table A1).

Comparison districts were selected to be similar to the intervention districts in terms of population size, density, and socio-economic factors. Comparison districts were not contiguous with the intervention districts in order to control for potential contamination of the interventions.

\subsection{QUESTIONNAIRES}

Two questionnaires were designed for the women's study: a household listing and a questionnaire for women aged 15 to 49. The questionnaires were drafted by Population Council staff drawing on previous questionnaires from the Population Council, the Demographic and Health Surveys (DHS), the Ethiopia Welfare Monitoring Surveys, and various instruments from the World Health Organization (WHO). For example, questions on domestic violence are taken from the specialized DHS questionnaire module, as well as numerous questions on family planning and HIV. Household assets are largely adapted from the Ethiopia Welfare Monitoring Surveys and DHS. Questions on alcohol are adapted from WHO instruments. All questionnaires were reviewed during a series of consultation meetings by the Population Council-Ethiopia study team, as well as technical staff from UNFPA and UNICEF. All questionnaires were finalized in English and translated into three local languages: Amharic, Oromiffa, and Tigrigna. Back-translation was undertaken to ensure accuracy of translations.

A household listing questionnaire was designed for the initial household census, to facilitate identification and selection of study respondents. The household listing format collected information on all household members in selected EAs. Information was collected on household members' age, sex, marital status, and relationship to the household head.

The questionnaire contained 16 sections:

1) Background characteristics of respondents;

2) Education and schooling experience;

3) Attitudes and self-esteem;

4) Migration;

5) Families;

6) Livelihoods;

7) Female genital mutilation/cutting;

8) Puberty;

9) Marriage;

10) Sexual experience;

11) HIV and other sexually transmitted infection (STI) knowledge, services and prevention;

12) Family planning;

13) Maternal health;

14) Drugs and alcohol;

15) Violence; and

16) Service access and utilization.

In addition, the questionnaire had a cover page that collected identifier information as well as an informed consent page. 


\subsection{DATA COLLECTION}

\section{Pretesting}

All questionnaires were pre-tested through four rounds, examining length, respondents' and interviewers' experience and perceptions of the questionnaire, understanding of the questionnaires, and accuracy of skip patterns. Pretests were made among both rural and urban respondents representing a range of ages and located outside of the study area. Revisions to the questionnaires were made at each round of pretest. In addition, questionnaires translated in local languages were pretested in those languages and additional revisions made after the pretests.

\section{Training}

In each region, a minimum of 36 interviewers, 6 supervisors, and 3 coordinators were recruited. Recruitment was undertaken with assistance of the Regional Bureaus of Statistics who conduct the EDHS and many other large surveys. Interviewers had a minimum of 10 years of education, were able to speak local languages, were familiar with the area, and had experience in previous surveys, especially the EDHS. In all, over 200 interviewers took part in the survey (See Appendix B).

Training was conducted in each region by Population Council staff. Interviewers were trained for seven days: one day on the household listing format and six days on the questionnaire. The questionnaires were reviewed item by item. Training included multiple practice interviews in pairs and in the larger group. Toward the end of the training, trainers organized a field visit where interviewers practiced the interview on respondents recruited from local organizations, outside of the study areas. Interviewers subsequently discussed the experience of the interview and clarified any remaining queries they had on the instruments.

\section{Household listing \& selection}

All EAs selected for the study first underwent a census of all households, or 'household listing, in order to establish a sampling frame for the locations. Interviewers went house-to-house to enumerate members of the households in the sampled EAs. Guides from the local community were recruited to guide interviewers, ensure all households were covered, and facilitate cooperation by households. Supervisors performed random checks to ensure accuracy and coverage of data.

Once households were listed, selection of respondents were made using a random number function available in SPSS. In each EA, 20 women aged 25 to 49 and 20 girls aged 12 to 24 were selected at random. Only one respondent was selected in each household. For this report, girls aged 12 to 14 are removed from analysis.

\section{Fieldwork}

Each data collection team included six interviewers and one supervisor. Regional coordinators worked across teams to facilitate sensitization of study areas, field logistics, and data quality. At least one Population Council staff member oversaw the data collection in the regions.

Only female interviewers interviewed female respondents. Interviewers visited the selected household to locate and interview the selected respondent. Interviewers were trained to conduct the interview in a private place, out of earshot of other household or community members. If the respondent was not at home, an appointment was made for a follow-up visit. Interviewers paid up to three visits to the household to locate and interview the selected respondent. In cases where he/she refused or could not be located, no replacement of the respondent was made. Prior to the interview, informed consent was obtained from respondents. Where the respondent was below the age of 18 , informed consent was also obtained from a parent or guardian.

\section{Data processing}

Data was entered at Population Council offices. Data was entered in an Epi-Info data entry screen that included embedded checks and skips to increase quality of entry. Two data managers checked and merged data being entered. Ultimately, these managers cleaned data by referring to hard copies of the questionnaires to clarify and correct any inconsistencies or inaccuracies in the dataset. The questionnaires were labeled and stored by region and serial number. All data is stored under lock and key at Population Council offices. 
Data were weighted in order to adjust for unequal probabilities of selection. Weights were calculated for each stage of sample selection, including selection of woredas, enumeration areas, and respondents within the household.

\subsection{RESPONSE RATES \& SAMPLE CHARACTERISTICS}

Response rates are a measure of data quality, with higher response rates reflecting higher quality, and more representative data. Table 1.1 shows the individual response rates for the women's survey. The total number of respondents sampled were 8,791, including 5,040 women aged 25 to 49. Among these, with 8,563 were eligible for the survey. Roughly 2 percent of sampled respondents were no longer eligible for survey as they moved out of the study area, or left for an extended period, between the time of household listing and the time of survey. Among those eligible for survey, 98 percent of sampled females were interviewed. In all, 8,397 women aged 15 to 49 were interviewed.

TABLE 1.1 Response rates of women's survey

\begin{tabular}{l|c|c}
\hline & Girls and women aged 15-49 \\
\hline Individuals sampled & 8,791 & $100 \%$ \\
Ineligible for survey & & \\
Moved away/away for extended period & 200 & $2.3 \%$ \\
Structure not found/out of age range & 28 & $0.3 \%$ \\
Total ineligible for survey & 228 & $2.6 \%$ \\
& & \\
Number of eligible individuals sampled & 8,563 & \\
Refused & 31 & $0.4 \%$ \\
Not at home/unable to locate after three visits & 56 & $0.7 \%$ \\
Incapacitated & 16 & $0.2 \%$ \\
Other reasons & 63 & $0.7 \%$ \\
Total non-response & 166 & $1.9 \%$ \\
Eligible individuals interviewed /response rate & 8,397 & 98.1 \\
\hline
\end{tabular}

Table 1.2 shows the characteristics of the sample. Weighted percentages are presented in the table, along with unweighted N's. Roughly one quarter of the sample were below the age of 20 and 42 percent were aged 20 to 29. Seventy-one percent of respondents were ever married, with considerably more rural women ever married (80 percent), compared to urban women (58 percent). Twelve percent of women were divorced at the time of survey.

Educational attainment was considerably different between the urban and rural samples. Sixty-nine percent of rural women had no education compared to 25 percent of urban women. Forty percent of urban women had 9 or more years of education, compared to 4 percent of rural women. Two thirds of respondents were Orthodox Christian, 18 percent of respondents were Muslim and 15 percent were Protestant. 
TABLE 1.2 Percent distribution of the female sample, by selected characteristics

\begin{tabular}{|c|c|c|c|c|c|c|}
\hline \multirow[t]{2}{*}{ Characteristic } & \multicolumn{2}{|c|}{ Urban } & \multicolumn{2}{|c|}{ Rural } & \multicolumn{2}{|c|}{ All women } \\
\hline & $\begin{array}{l}\text { Weighted } \\
\text { percent }\end{array}$ & Number & $\begin{array}{c}\text { Weighted } \\
\text { percent }\end{array}$ & Number & $\begin{array}{c}\text { Weighted } \\
\text { percent }\end{array}$ & Number \\
\hline \multicolumn{7}{|l|}{ Age group } \\
\hline $\begin{array}{l}15 \text { to } 19 \\
20 \text { to } 29 \\
30 \text { to } 39\end{array}$ & $\begin{array}{l}26.9 \\
44.7 \\
19.0\end{array}$ & $\begin{array}{c}783 \\
1434 \\
706\end{array}$ & $\begin{array}{l}23.1 \\
40.7 \\
22.2\end{array}$ & $\begin{array}{l}1110 \\
2090 \\
1223\end{array}$ & $\begin{array}{l}24.6 \\
42.3 \\
20.9\end{array}$ & $\begin{array}{l}1893 \\
3524 \\
1929\end{array}$ \\
\hline 40 to 49 & 9.4 & 327 & 14.0 & 723 & 12.2 & 1050 \\
\hline \multicolumn{7}{|l|}{ Marital Status } \\
\hline Never married & 42.3 & 1184 & 20.0 & 970 & 28.8 & 2154 \\
\hline Married /cohabiting & 44.5 & 1587 & 68.3 & 3586 & 58.9 & 5173 \\
\hline Divorced/separated/widowed & 13.2 & 465 & 11.7 & 580 & 12.3 & 1045 \\
\hline \multicolumn{7}{|l|}{ Region } \\
\hline Tigray & 3.7 & 229 & 11.7 & 965 & 8.5 & 1194 \\
\hline Afar & 5.2 & 522 & 4.3 & 708 & 4.7 & 1230 \\
\hline Amhara & 21.0 & 293 & 40.0 & 918 & 32.4 & 1211 \\
\hline Oromiya & 20.6 & 376 & 26.4 & 830 & 24.1 & 1206 \\
\hline Benishangul-Gumuz & 0.7 & 246 & 2.4 & 978 & 1.7 & 1224 \\
\hline SNNPR & 14.1 & 441 & 15.2 & 748 & 14.8 & 1189 \\
\hline Addis Ababa & 34.7 & 1143 & - & - & 13.8 & 1143 \\
\hline \multicolumn{7}{|l|}{ School Status } \\
\hline $\begin{array}{l}\text { Out of school } \\
\text { In school }\end{array}$ & $\begin{array}{l}72.5 \\
27.5\end{array}$ & $\begin{array}{c}2458 \\
776\end{array}$ & $\begin{array}{l}88.0 \\
12.0\end{array}$ & $\begin{array}{c}4590 \\
537\end{array}$ & $\begin{array}{l}81.8 \\
18.2\end{array}$ & $\begin{array}{l}7048 \\
1313\end{array}$ \\
\hline \multicolumn{7}{|l|}{ Educational attainment } \\
\hline No Education & 25.3 & 965 & 69.0 & 3594 & 51.6 & 4559 \\
\hline 1 to 4 years of education & 12.0 & 370 & 14.9 & 742 & 13.8 & 1112 \\
\hline 5 to 8 years of education & 22.7 & 737 & 12.1 & 617 & 16.3 & 1354 \\
\hline $9+$ years of education & 40.0 & 1162 & 4.0 & 180 & 18.3 & 1342 \\
\hline \multicolumn{7}{|l|}{ Religion } \\
\hline Orthodox Christian & 65.7 & 1924 & 66.0 & 2632 & 65.9 & 4556 \\
\hline Muslim & 18.7 & 15 & 17.4 & 46 & 17.9 & 2502 \\
\hline Protestant & 15.0 & 869 & 15.1 & 1633 & 15.1 & 1161 \\
\hline Catholic & 0.3 & 426 & 1.0 & 735 & 0.7 & 61 \\
\hline Other & 0.3 & 9 & 0.5 & 77 & 0.4 & 86 \\
\hline
\end{tabular}




\section{Chapter Two: Household Characteristics}

\subsection{HOUSEHOLD COMPOSITION}

Table 2.1 shows the household size and headship among women in the sample. Sixteen percent of women were heads of their households with considerably more urban women heading the households (24 percent) compared to rural women (11 percent).

TABLE 2.1 Household composition: Household heads and number of usual household members, by type of place of residence

\begin{tabular}{lccc}
\hline Characteristic & Urban $(\mathbf{n = 3 , 2 4 2})$ & Rural $(\mathbf{n = 5 , 1 3 4 )}$ & All $(\mathbf{n = 8 , 3 7 6 )}$ \\
\hline Respondent is household head (all) & 24.1 & 10.8 & 16.0 \\
& & & \\
Number of usual household members & & & 2.4 \\
1 & 4.5 & 1.0 & 9.7 \\
2 & 12.7 & 7.8 & 15.5 \\
3 & 18.0 & 13.7 & 16.9 \\
4 & 17.1 & 16.8 & 16.9 \\
5 & 17.0 & 16.8 & 14.2 \\
6 & 12.1 & 15.7 & 10.6 \\
7 & 7.4 & 12.7 & 6.8 \\
8 & 5.0 & 7.9 & 7.0 \\
$9+$ & 6.2 & 7.6 & 100.0 \\
Total & & & 5.0 \\
\hline
\end{tabular}

The average household size of respondents is 5 members, which is comparable to the EDHS (2005). Rural females tend to live in larger households (mean 5.3 members) compared to urban females (mean 4.6 members), also similar to patterns in the EDHS.

TABLE 2.2 Household composition: Percentage of respondents residing with family and non-family members, by category of co-resident and type of place of residence

\begin{tabular}{lccc}
\hline Characteristic & Urban $(\mathbf{n = 3 , 2 4 2})$ & Rural $(\mathbf{n = 5 , 1 3 4 )}$ & All $(\mathbf{n = 8 , 3 7 6 )}$ \\
\hline Children of one's own & 49.5 & 69.7 & 62.0 \\
Husband/partner & 48.1 & 70.2 & 61.8 \\
Parent(s) & 30.4 & 30.1 & 30.3 \\
Sibling & 36.5 & 26.1 & 30.3 \\
Other relative & 23.8 & 9.6 & 15.3 \\
Children of someone else & 9.5 & 6.1 & 7.4 \\
Domestic worker & 8.6 & 1.3 & 4.2 \\
Employer & 4.1 & 0.3 & 1.8 \\
Friend (male or female) & 1.6 & 0.9 & 1.1 \\
Co-workers & 1.1 & 0.3 & 0.6 \\
\hline
\end{tabular}


Table 2.2 shows the percentage of female respondents co-residing with various categories of people. The most common co-resident among respondents was their own children ( 62 percent) and husbands (62 percent), followed by parents (30 percent) and siblings (30 percent). Compared to rural households, urban households had a greater diversity of members, with a considerable number of urban households including other relatives (24 percent), someone else's children (10 percent), and domestic workers ( 9 percent).

Most respondents own their residence (76 percent), especially those in rural areas (96 percent) (Table 2.3). Among urban respondents, 46 percent own their residence, 32 percent rent from a private owner, and 17 percent rent from the kebele ${ }^{12}$ administration. Those renting from the kebele pay an average of 27 Birr per month (US \$2), while those renting from a private owner pay an average of 162 Birr per month (US \$12).

TABLE 2.3 Household composition: Percentage of respondents owning or renting their place of residence, by type of place of residence

\begin{tabular}{lccc}
\hline Characteristic & Urban $(\mathbf{n = 3 , 2 4 2})$ & Rural $(\mathbf{n = 5 , 1 3 4 )}$ & All $(\mathbf{n = 8 , 3 7 6 )}$ \\
\hline Own residence & 45.8 & 95.8 & 76.0 \\
Rent from the kebele & 16.5 & 0.1 & 6.6 \\
Rent from a private owner & 32.2 & 1.3 & 13.6 \\
Other* & 5.5 & 2.8 & 3.8 \\
\hline *ther includes provided by relatives or employers & &
\end{tabular}

\subsection{HOUSEHOLD POSSESSIONS \& AMENITIES}

Household facilities and possessions reflect the general status and wellbeing of members of the household, as well as potential health threats from unsafe facilities. Respondents were asked about sources of their household's drinking water, type of toilet, and other basic possessions in the household.

Most urban households had improved water sources including water piped into the compound (49 percent) and water from a public tap (33 percent) (Table 2.4). Most rural households had non-improved sources such as rivers, lakes or ponds (34 percent) or unprotected wells and springs (29 percent). Twenty-one percent of rural households have access to piped water or water from a tap. While 31 percent of respondents considered their drinking water unsafe, 91 percent did nothing to treat the drinking water.

Time to the source of drinking water varied between urban and rural areas. Most urban households (82 percent) took less than 10 minutes to and from the source of their drinking water and 8 percent travelled 30 minutes or more to and from the source. By contrast, 28 percent of rural respondents spent less than 10 minutes in fetching water and 48 percent spent 30 minutes or longer. Eighty-nine percent of respondents report that they fetch water for their household, 86 percent of urban women and 90 percent of rural women.

${ }^{12}$ Kebele is the lowest administrative unit in Ethiopia. 
TABLE 2.4 Household drinking water: Percent of households by source of water, time to source, perceived safety, and access, by type of place of residence

\begin{tabular}{|c|c|c|c|}
\hline Characteristic & Urban $(n=3,234)$ & Rural $(n=5,142)$ & All $(n=8,376)$ \\
\hline \multicolumn{4}{|l|}{ Source } \\
\hline Improved source & 93.4 & 37.0 & 59.4 \\
\hline Purchased bottled water & 0.5 & 0.3 & 0.4 \\
\hline Piped in dwelling & 7.8 & 0.1 & 3.1 \\
\hline Piped in compound & 48.9 & 0.8 & 19.9 \\
\hline Public tap & 32.7 & 20.5 & 25.4 \\
\hline Protected well/spring & 3.3 & 15.0 & 10.3 \\
\hline Rainwater & 0.2 & 0.3 & 0.3 \\
\hline Non-improved source & 6.6 & 63.0 & 40.6 \\
\hline Unprotected well/spring & 5.2 & 29.2 & 19.7 \\
\hline River, lake or pond & 1.4 & 33.8 & 20.9 \\
\hline \multicolumn{4}{|l|}{ Time to obtain drinking water (round trip) } \\
\hline Less than 10 minutes & 82.1 & 28.2 & 49.5 \\
\hline 11 to 29 minutes & 10.0 & 23.4 & 18.1 \\
\hline 30 minutes or longer & 7.9 & 48.4 & 32.4 \\
\hline \multicolumn{4}{|l|}{ Water treated prior to drinking } \\
\hline Not treated & 90.0 & 91.8 & 91.1 \\
\hline Boiled & 2.1 & 1.6 & 1.8 \\
\hline Filtered & 1.1 & 3.0 & 2.3 \\
\hline WaterGuard/Pur ${ }^{\mathrm{TM}}$ & 5.5 & 2.8 & 3.9 \\
\hline Two or more methods* & 0.8 & 0.7 & 0.7 \\
\hline Other & 0.5 & 0.1 & 0.2 \\
\hline \multicolumn{4}{|l|}{$\begin{array}{l}\text { Water considered 'safe'/will not cause } \\
\text { sickness }\end{array}$} \\
\hline Yes & 70.2 & 68.8 & 69.3 \\
\hline No & 29.8 & 31.2 & 30.7 \\
\hline \multicolumn{4}{|l|}{$\begin{array}{l}\text { Household's access to safe water increased, } \\
\text { decreased or not changed in last year }\end{array}$} \\
\hline Increased & 21.9 & 16.2 & 18.5 \\
\hline Decreased & 15.5 & 18.5 & 17.3 \\
\hline Remained the same & 59.9 & 64.5 & 62.7 \\
\hline Don't know/new member of household & 2.7 & 0.8 & 1.5 \\
\hline
\end{tabular}

* Indicates two or more methods including boiling, filtering or use of WaterGuard/Pur

Table 2.5 shows the toilet facilities and possessions of respondents' households. Eighty-eight percent of urban households had improved toilets whereas less than 48 percent of rural households had them. The most common type of toilet was a pit latrine (60 percent), followed by fields or forests (36 percent).

Compared to rural areas, urban households have significantly higher levels of ownership of personal effects. Seventy-six percent of urban households own a radio compared to 30 percent of rural households; 53 percent of urban households possess a television, compared to 1 percent of rural households; 52 percent 
of urban households own a mobile phone compared to 4 percent of rural households. In contrast, rural households are more likely to possess agricultural land or animals. Ninety percent of rural households possess agricultural land compared to 12 percent of urban households; 84 percent of rural households have farm animals compared to 13 percent of urban households.

TABLE 2.5 Household sanitation facilities and possessions: Percent of households by type of toilet/latrine and possessing various household effects and assets, by type of place of residence

\begin{tabular}{|c|c|c|c|}
\hline Characteristic & Urban $(n=3,241)$ & Rural $(n=5,140)$ & All $(n=8,381)$ \\
\hline \multicolumn{4}{|l|}{ Type of toilet/latrine } \\
\hline Improved & 87.7 & 47.7 & 63.6 \\
\hline Flush toilet, private & 5.3 & 0.3 & 2.3 \\
\hline Flush toilet, shared & 1.6 & 0.1 & 0.7 \\
\hline Pit latrine, private & 36.2 & 42.7 & 40.1 \\
\hline Pit latrine, shared & 44.1 & 4.5 & 20.3 \\
\hline Other $^{1}$ & 0.5 & 0.2 & 0.3 \\
\hline Non-improved source & 12.3 & 52.3 & 36.4 \\
\hline Container (from household items) & 0.5 & 0.2 & 0.3 \\
\hline Field or forest & 11.8 & 52.1 & 36.1 \\
\hline \multicolumn{4}{|l|}{ Main material of the roof } \\
\hline Corrugated iron sheets & 96.0 & 35.4 & 59.6 \\
\hline Thatch or grass & 2.5 & 56.8 & 35.1 \\
\hline Other ${ }^{2}$ & 1.5 & 7.8 & 5.3 \\
\hline \multicolumn{4}{|l|}{ Main type of cooking fuel } \\
\hline Collected firewood & 14.1 & 78.6 & 53.0 \\
\hline Purchased firewood & 38.2 & 5.0 & 18.2 \\
\hline Charcoal & 23.0 & 0.4 & 9.9 \\
\hline Leaves/dung cakes & 1.5 & 13.5 & 8.7 \\
\hline Kerosene & 15.5 & 0.1 & 6.2 \\
\hline Butane & 6.5 & 0.0 & 2.6 \\
\hline Electricity & 0.9 & 0.2 & 0.5 \\
\hline Other & 0.3 & 2.1 & 1.4 \\
\hline \multicolumn{4}{|l|}{ Household amenities and effects } \\
\hline Radio & 76.1 & 30.0 & 48.8 \\
\hline Television & 53.0 & 1.1 & 21.7 \\
\hline Mobile phone & 52.0 & 3.9 & 23.0 \\
\hline Non-mobile/fixed phone & 36.1 & 0.2 & 14.5 \\
\hline Household has electricity & 87.8 & 3.8 & 37.3 \\
\hline Household ownership of agricultural land & 12.4 & 89.6 & 59.0 \\
\hline Household ownership of farm animals ${ }^{3}$ & 12.5 & 83.9 & 55.6 \\
\hline
\end{tabular}


The vast majority of households used firewood for cooking ( 71 percent), followed by charcoal (10 percent) or leaves/dung cakes ( 9 percent). In particular, rural households consumed firewood for cooking ( 84 percent).

Respondents were read a list of items and asked if they personally own or possess them (Table 2.6). Possessions included basic items such as shoes, a blanket and a change of clothing, as well as status items such as mobile phone. Personal ownership of all items was higher in urban areas compared to rural areas. Roughly 1 in 4 rural women do not have shoes; nearly half of rural women do not own a blanket; only 8 percent of rural women own radios.

TABLE 2.6 Individual possessions: Individual ownership of items, by type of place of residence

\begin{tabular}{lccc}
\hline Type of item & Urban $(\mathbf{n = 3 , 2 4 1 )}$ & Rural $(\mathbf{n = 5 , 1 4 0 )}$ & All $(\mathbf{n = 8 , 3 8 1 )}$ \\
\hline Change of clothing (3 or more outfits) & 94.0 & 75.5 & 83.0 \\
Shoes & 95.1 & 71.0 & 80.7 \\
Blanket & 62.7 & 55.0 & 58.1 \\
Radio & 27.7 & 8.4 & 16.1 \\
Mobile phone & 26.5 & 1.0 & 11.2 \\
\hline
\end{tabular}




\section{Chapter Three: Migration}

Migration is the movement of a person or people from one location to another, either as individuals or in groups. Migration can be voluntary, such as when people move in pursuit of education or work, or involuntary, such as in cases of human trafficking, warfare or environmental degradation. Migration may result from 'push factors' that encourage migrants to leave one area for another, or 'pull factors' that attract migrants to a particular area. Examples of 'push factors' are lack of educational or job opportunities, lack of infrastructure, famine and drought, political fear or persecution. 'Pull factors' include job opportunities, better living standards, healthcare, or family ties.

Overall, 39 percent of women are not native to their area of residence (Table 3.1). Fifty-six percent of urban women and 27 percent of rural women migrated from another area to their current place of residence. Most rural migrants had migrated from another rural area (88 percent), whereas 64 percent of urban migrants had come from a rural area and 36 percent had migrated from another city or smaller town.

TABLE 3.1 Migration: Percent of women who are migrant to the area, by selected characteristics

\begin{tabular}{lccc}
\hline Characteristic & Urban $(n=3,241)$ & Rural $(n=5,140)$ & All $(n=8,381)$ \\
\hline All respondents & 56.1 & 27.0 & 38.6
\end{tabular}

Age group

15 to 19

20 to 29

30 to 39

40 to 49

Region

Tigray

Affar

Amhara

Oromiya

Benishangul- Gumuz

SNNP

Addis Ababa

\section{Educational attainment}

No education
Primary
Secondary
University

Type of place of origin*

$\begin{array}{ll}\text { Rural area } & 63 \\ \text { Small town } & 22 \\ \text { Big city } & 14\end{array}$

* Among migrants
70.8

66.9

48.0

54.2

59.4

56.6

26.8

21.0

28.2

24.1

45.4

28.2

58.8

68.6

62.8

42.5

41.3
28.9

21.2

31.5

100.0
34.5

41.4

33.3

34.4

47.6

38.7

58.8

40.3

41.0

43.3 
Reasons for migration differed between urban and rural residents (Table 3.2). The main reason that rural women migrated was in connection with marriage, to live with a spouse or partner ( 74 percent). Among rural migrants only a few women migrated for other regions such as accompanying family members ( 6 percent), for work ( 6 percent), or because of famine or poverty (4 percent). Among rural migrants, 66 percent migrated during adolescence, between the ages of 10 to 19. Given that most rural girls migrated in the context of marriage, age at migration likely coincided with age at marriage for many rural migrants. Further, 88 percent of rural migrants moved on their own or with a spouse/partner.

Urban migrants relocated for a broad array of reasons including for work (28 percent), to join spouse or partner (25 percent), for schooling (21 percent) and to accompanying moving family members (14 percent). Urban migrants migrated with a broad array of people including spouse partner (27 percent), on their own (25 percent), other relatives (19 percent), and parents (15 percent).

TABLE 3.2 Migration: Reasons for migration, age at migration and co-migrants, by type of place of residence

\begin{tabular}{lccc}
\hline Characteristic & Urban $(\mathbf{n = 3 , 2 4 1 )}$ & Rural $(\mathbf{n = 5 , 1 4 0 )}$ & All $(\mathbf{n}=\mathbf{8 , 3 8 1})$ \\
\hline Reason(s) for migrating* & & & \\
To live with spouse/partner & 24.7 & 74.4 & 45.9 \\
For work & 27.5 & 5.8 & 18.3 \\
For schooling & 21.2 & 0.8 & 12.5 \\
Accompanying family & 13.7 & 6.2 & 10.5 \\
Personal problems at home & 4.3 & 1.3 & 3.0 \\
Famine/poverty in other area & 1.3 & 4.3 & 2.6 \\
Death of parents/guardians & 2.7 & 0.4 & 1.7 \\
Other & 0.2 & 0.4 & 0.3
\end{tabular}

\section{Age at migration}

Below age 10

10 to 14

\section{Person with whom migrated*}

\begin{tabular}{lccc} 
Spouse / partner & 26.6 & 46.6 & 35.1 \\
No one & 24.6 & 40.9 & 31.5 \\
Other relatives & 19.4 & 3.4 & 12.3 \\
Parent(s) & 14.8 & 6.7 & 11.3 \\
Siblings & 13.4 & 1.7 & 8.2 \\
Non relatives & 5.6 & 3.9 & 4.9 \\
Own children & 5.0 & 3.4 & 4.2 \\
Employer & 0.7 & 0.3 & 0.5 \\
Other & 1.2 & 2.0 & 1.6 \\
\hline
\end{tabular}




\section{Chapter Four: Attitudes \& Social Participation}

\subsection{ATTITUDES}

Respondents were read a series of statements related to attitudes towards gender roles, education, and domestic duties and asked whether they agreed or disagreed with the statements. Table 4.1 shows the extent of inequitable gender attitudes among respondents. The majority of respondents believed it is 'unmanly' for a boy or man to cry (57 percent) and 48 percent believed that women should be controlled by men. A considerable proportion of respondents held inequitable attitudes about education and domestic work. For example, 46 percent believed that boys are usually better at math than girls and 41 percent disagreed with the statement 'Boys should do as much domestic work as girls.' On every statement presented, rural respondents were more likely to hold gender inequitable attitudes than urban respondents.

TABLE 4.1: Attitudes: Inequitable gender attitudes among women aged 15 to 49 , by type of place of residence

Urban $(n=3,234) \quad$ Rural $(n=5,133) \quad$ All $(n=8,367)$

\section{Attitudes about gender roles}

Agree with 'It is unmanly for a boy or man to cry.'

45.9

27.4

Agree with 'Women should be controlled by men.'

Disagree with 'Girls can make as good leaders as boys.'

9.4
39.4

29.4

12.6

20.0

Agree with 'Girls are not as good as boys in school.'

\section{Attitudes about domestic work}

Disagree with 'Boys should do as much domestic work as girls.'

Agree with 'Boys should not be asked to help their mothers prepare food.'

Agree with 'Men should not care for children if a woman is around.'

Agree with 'Men should not fetch water if a woman or girl is around.'
23.7

29.2

22.7

14.2

\section{Attitudes toward education}

Agree with 'Most girls are lazy in school.'
64.4

57.0

61.8

48.0

31.4

22.7

36.6

33.7

Respondents were read a series of statements related to perceptions of self worth and self esteem (Table 4.2). A considerable proportion of women reflected negative attitudes about themselves. One quarter of women disagreed with the statement that they feel as intelligent as most of their peers; 24 percent agreed that they feel worthless at times. Nineteen percent of rural women and 11 percent of urban women said that they do not have hope for the future. 
TABLE 4.2: Attitudes: Negative self perceptions of among women aged 15 to 49, by type of place of residence

\begin{tabular}{|c|c|c|c|}
\hline & Urban $(n=3,234)$ & Rural $(n=5,133)$ & All $(n=8,367)$ \\
\hline Disagree with 'You feel as intelligent as most other people your age.' & 23.9 & 25.9 & 25.1 \\
\hline Agree with 'At times, you feel you are no good at all/worthless.' & 20.6 & 25.6 & 23.6 \\
\hline Agree with 'You do not have hope for the future.' & 11.2 & 19.4 & 16.1 \\
\hline Agree with 'At times, you feel like a failure.' & 11.5 & 18.0 & 15.4 \\
\hline
\end{tabular}

\subsection{SOCIAL SUPPORT \& REGULATION}

Social networks and participation can reflect the extent to which individuals are actively engaged in society. In order to reflect social networks, respondents were asked how many close friends they have in their community. On average, respondents reported having roughly two friends (mean 1.8). A considerable proportion of women ( 25 percent) reported having no friends. In particular, a significant proportion of urban women (30 percent) reported that they have no friends, while 21 percent of rural women reported no friends.

Girls and women experienced a high level of control by family members. Eighty-two percent of respondents said that their husbands or parents know their whereabouts at all times and 78 percent said that they need permission before leaving the house. Rural women reported higher levels of control compared to urban women, with over 80 percent of rural women requiring permission before leaving the house, visiting a friend, or taking part in a youth or women's club.

TABLE 4.3: Social participation: Percentage of women aged 15 to 49 needing permission before engaging in activities, by activity and type of place of residence

\begin{tabular}{|c|c|c|c|}
\hline & Urban $(n=3,234)$ & Rural $(n=5,133)$ & All $(n=8,367)$ \\
\hline Parents or husband know respondent's whereabouts at all times. & 72.9 & 87.3 & 81.5 \\
\hline Needs permission before leaving the house after dark. & 72.9 & 86.1 & 80.8 \\
\hline Needs permission before leaving the house. & 66.7 & 85.1 & 77.8 \\
\hline Needs permission before visiting a friend. & 65.7 & 82.0 & 75.5 \\
\hline Needs permission before attending a woman's group or youth group. & 65.4 & 82.1 & 75.5 \\
\hline
\end{tabular}

Respondents were read a series of statement to reflect the level of support they have in their own communities. Statements related to assistance in the case of medical emergencies, confiding in someone about violence, having alternative places to stay and people from whom to borrow money (Table 4.4). Rural respondents reflected a greater degree of social support on all issues mentioned. Sixty-one percent of rural women said they had a source of support in case of a medical emergency, compared to 51 percent of urban women; 53 percent of rural women said they had another place they could stay in case of problems in the house, compared to 39 percent of urban women. The lowest reporting of social support was having a person from whom one could borrow money (42 percent), which could reflect both lack of social networks as well as generalized poverty in the respondents' communities.

TABLE 4.4: Social support: Percentage of women aged 15 to 49 reporting sources of support in the community, by support and type of place of residence

\begin{tabular}{|c|c|c|c|}
\hline & $\begin{array}{c}\text { Urban } \\
(n=3,234)\end{array}$ & $\begin{array}{c}\text { Rural } \\
(n=5,133)\end{array}$ & $\begin{array}{c}\text { All } \\
(n=8,367)\end{array}$ \\
\hline There is someone in the community who would assist in case of a medical emergency & 51.3 & 61.0 & 57.1 \\
\hline There is someone in the community who she could confide in about domestic violence & 51.4 & 59.2 & 56.1 \\
\hline $\begin{array}{l}\text { There is someone in the community who she could stay with if she had a problem in } \\
\text { her household }\end{array}$ & 39.4 & 52.5 & 47.3 \\
\hline There is someone in the community from whom she can borrow money & 38.0 & 44.2 & 41.7 \\
\hline
\end{tabular}




\section{Chapter Five: Education}

\subsection{SCHOOL ATTENDANCE}

Seventy-five percent of urban females and 31 percent of rural females had ever attended school (Table 5.1). Respondents in the younger age groups were significantly more likely to have ever attended school compared to those in the older age groups, reflecting recent expansion of schooling in the country. For example, whereas 40 percent of urban women aged 40 to 49 had attended, 91 percent of urban girls aged 15 to 19 had been to school; while only 6 percent of rural women aged 40 to 49 had been to school, 64 percent of the young rural women aged 15 to 19 had been. The highest rates of ever attendance of school was in Addis Ababa (79 percent), SNNPR (64 percent) and Oromiya (52 percent).

TABLE 5.1: Education: Percent of women aged 15-49 who have ever been to school and reasons for non-attendance, by type of place of residence and selected characteristics

\begin{tabular}{|c|c|c|c|}
\hline Characteristic & Urban $(n=3,246)$ & Rural $(n=5,138)$ & All $(n=8,384)$ \\
\hline All respondents & 74.5 & 30.9 & 48.3 \\
\hline \multicolumn{4}{|l|}{ Age group } \\
\hline $\begin{array}{l}15 \text { to } 19 \\
20 \text { to } 29 \\
30 \text { to } 39 \\
40 \text { to } 49\end{array}$ & $\begin{array}{l}90.5 \\
76.3 \\
64.7 \\
40.3\end{array}$ & $\begin{array}{c}64.4 \\
29.9 \\
13.4 \\
6.0\end{array}$ & $\begin{array}{l}75.8 \\
49.4 \\
31.9 \\
16.6\end{array}$ \\
\hline \multicolumn{4}{|l|}{ Region } \\
\hline Tigray & 68.3 & 30.9 & 37.4 \\
\hline Afar & 52.4 & 13.0 & 30.5 \\
\hline Amhara & 55.8 & 22.8 & 31.3 \\
\hline Oromiya & 85.7 & 34.5 & 51.9 \\
\hline Benishangul-Gumuz & 47.8 & 29.1 & 32.0 \\
\hline SNNPR & 85.4 & 51.4 & 64.3 \\
\hline Addis Ababa & 79.4 & - & 79.4 \\
\hline \multicolumn{4}{|l|}{ Reason(s) for not attending* } \\
\hline Family does not approve & 45.5 & 54.1 & 52.4 \\
\hline Got married & 16.0 & 23.2 & 21.8 \\
\hline Family could not afford & 29.8 & 17.0 & 19.5 \\
\hline No school in vicinity/no school places & 13.1 & 17.8 & 16.9 \\
\hline Too many domestic/farming/herding & 12.2 & 11.9 & 11.9 \\
\hline Death of parents or family members & 6.0 & 4.8 & 5.0 \\
\hline No interest in schooling & 3.5 & 2.0 & 2.3 \\
\hline Sickness or disability & 1.0 & 0.7 & 0.8 \\
\hline Pregnancy & 0.3 & 0.5 & 0.4 \\
\hline
\end{tabular}

The main reasons cited for not attending school were family disapproval (52 percent), marriage (22 percent), poverty (20 percent) and lack of schooling facilities (17 percent). Family disapproval and marriage were more common reasons among rural women whereas urban women were more likely to cite poverty or the family not being able to afford schooling. 
Among females who attended school, age at entry was relatively late, especially among rural respondents. Forty-six percent of women started school at age 9 or older, and 13 percent started after age 12; among rural women, 66 percent started at age 9 or older and 19 percent started after age 12. The most common reasons cited for leaving school were marriage ( 28 percent), families not being able to afford schooling ( 23 percent) and the burden of domestic duties (22 percent). Pregnancy was a minor reason for school-leaving, mentioned by only 3 percent of respondents as the reason for leaving school.

TABLE 5.2: Education: Age at school entry, age at school leaving, and reasons for leaving school by type of place of residence

\begin{tabular}{lccc}
\hline Characteristic & Urban $(\mathbf{n = 2 , 2 6 0})$ & Rural $(\mathbf{n = 1 , 5 4 2})$ & All $(\mathbf{n}=\mathbf{3 , 8 0 2})$ \\
\hline Age at entry into school & & & 5.8 \\
$\quad$ Less than 6 years & 8.2 & 1.9 & 48.6 \\
6 to 8 years & 58.8 & 32.5 & 22.1 \\
9 to 10 years & 17.7 & 29.1 & 10.4 \\
11 to 12 years & 5.9 & 17.7 & 13.1 \\
13+ years & 9.4 & 18.8 & 9.1 \\
& & & 10.2
\end{tabular}

\section{Age at school leaving}

Less than 10 years

10 to 12 years old

13 to 14 years old

15 to 17 years old

$18+$ years old

Mean age at school leaving

\section{Reason(s) for leaving school*}

\begin{tabular}{lccc} 
Got married & 21.0 & 38.6 & 27.7 \\
Family could not afford & 25.0 & 18.5 & 22.5 \\
Domestic duties/farming/herding & 22.1 & 22.3 & 22.1 \\
Completed school cycle & 14.0 & 3.6 & 10.0 \\
Poor performance & 11.9 & 3.3 & 8.5 \\
No interest in school & 7.1 & 7.0 & 7.1 \\
Parents disapprove of school & 2.7 & 10.0 & 5.5 \\
Death/sickness of family member & 5.0 & 6.3 & 5.5 \\
Personal sickness or disability & 4.6 & 5.5 & 5.0 \\
Pregnancy & 3.7 & 2.7 & 3.3 \\
School too far/no school places & 2.1 & 3.3 & 2.6 \\
To work/support oneself & 2.9 & 1.9 & 2.4 \\
Other** & 4.3 & 4.5 & 4.3 \\
\hline grentage may sum to over 100, as more than one reason is possible; ${ }^{* *}$ Other includes migration, not knowing the language of instruction,
\end{tabular}

\subsection{EDUCATIONAL ATTAINMENT}

Table 5.3 shows literacy levels and educational attainment among women in the sample. Rural women are significantly more likely to be illiterate compared to urban women with 75 percent of rural women reporting illiteracy compared to 26 percent of urban women. Similarly, levels of educational attainment are generally 
lower for rural women compared to urban women. While 40 percent of urban women have 9 or more years of education, only 4 percent of rural women have attained this level of schooling. Only 1 percent of women have university-level education.

TABLE 5.3 Education: Literacy and number of years of schooling attained by type of place of residence

\begin{tabular}{|c|c|c|c|}
\hline Characteristic & Urban $(n=3,234)$ & Rural (n= 5,133) & All $(n=8,367)$ \\
\hline \multicolumn{4}{|l|}{ Literacy } \\
\hline Reads easily & 61.8 & 14.2 & 33.2 \\
\hline Reads with difficulty & 12.6 & 10.9 & 11.6 \\
\hline Cannot read at all & 25.6 & 74.9 & 55.2 \\
\hline \multicolumn{4}{|l|}{ Educational attainment } \\
\hline None & 25.9 & 69.5 & 52.2 \\
\hline 1 to 4 years & 11.5 & 14.6 & 13.3 \\
\hline 5 to 8 years & 22.7 & 12.0 & 16.3 \\
\hline 9 to 10 years & 27.9 & 3.6 & 13.3 \\
\hline 11 to 12 years & 9.5 & 0.2 & 3.9 \\
\hline University & 2.5 & 0.1 & 1.0 \\
\hline
\end{tabular}

Table 5.4 shows the educational attainment of respondents by age group and region. The years of educational attainment has steadily increased across cohorts of women. Among the oldest group aged 40 to 49, females had an average of 1 year of education; women in their 30's have an average of over 2 years; and those in their 20's have an average of 4 years. Among the youngest cohort, respondents had an average of 5 years of schooling, showing the steady expansion of schooling in the recent past. Respondents from Addis Ababa had the highest level of educational attainment (mean 6.6 years), followed by those from SNNPR (mean 4.3 years) and Oromiya (mean 3.5 years).

TABLE 5.4: Educational attainment: Mean years of schooling attained by type of place of residence, age group and region

\begin{tabular}{lccc}
\hline Characteristic & Urban $(\mathbf{n = 3 , 2 3 4 )}$ & Rural $(\mathbf{n}=\mathbf{5 , 1 3 3})$ & All $(\mathbf{n}=\mathbf{8 , 3 6 7})$ \\
\hline Age group & & & \\
15 to 19 & 6.9 & 3.5 & 5.0 \\
20 to 29 & 6.4 & 1.6 & 3.6 \\
30 to 39 & 5.5 & 0.6 & 2.4 \\
40 to 49 & 3.1 & 0.2 & 1.1 \\
& & & 2.3 \\
Region & & & 1.9 \\
Tigray & 5.3 & 1.6 & 2.1 \\
Afar & 3.6 & 0.5 & 3.5 \\
Amhara & 4.5 & 1.2 & 1.8 \\
Oromiya & 6.9 & 1.7 & 4.3 \\
Benishangul-Gumuz & 3.4 & 1.5 & 6.6 \\
SNNPR & 7.0 & 2.6 & - \\
Addis Ababa & 6.6 & - & \\
\hline
\end{tabular}




\section{Chapter Six: Livelihoods}

'Livelihoods' encompasses capabilities, resources and opportunities that enable people (women and men) to pursue individual and household economic goals. ${ }^{13}$ The livelihoods' framework places people and their available assets at the center of understanding how individuals and households make a living and improve their living conditions.

\subsection{PAID WORK}

Overall, 36 percent of women in the study had ever worked for pay, with 45 percent of urban women having worked for pay compared to 30 percent of rural women (Table 6.1). As expected, the percent of women who had worked for pay, increased with age. A considerable percentage of women have worked for pay in Tigray (67 percent), Addis Ababa (54 percent), Oromiya (43 percent) and Afar (43 percent). Only 16 percent of Amhara women had worked for pay. Formerly married women were considerably more likely to have worked for pay (51 percent) compared to never married women (31 percent) or married women (35 percent).

TABLE 6.1 Livelihoods: Percent of women who have ever worked for pay, by selected characteristics

\begin{tabular}{|c|c|c|c|}
\hline Characteristic & Urban $(n=3,241)$ & Rural $(n=5,140)$ & All $(n=8,381)$ \\
\hline Ever worked for pay & 45.3 & 29.9 & 36.0 \\
\hline \multicolumn{4}{|l|}{ Age group } \\
\hline 15 to 19 & 24.7 & 16.8 & 20.2 \\
\hline 20 to 29 & 49.4 & 33.2 & 40.0 \\
\hline 30 to 39 & 59.6 & 35.1 & 44.0 \\
\hline 40 to 49 & 55.6 & 33.6 & 40.3 \\
\hline \multicolumn{4}{|l|}{ Region } \\
\hline Tigray & 65.2 & 67.4 & 67.0 \\
\hline Affar & 50.7 & 35.9 & 42.5 \\
\hline Amhara & 28.0 & 11.3 & 15.6 \\
\hline Oromiya & 50.2 & 38.7 & 42.6 \\
\hline Benishangul- Gumuz & 26.1 & 23.4 & 23.8 \\
\hline SNNPR & 36.7 & 35.2 & 35.7 \\
\hline Addis Ababa & 53.9 & - & 53.9 \\
\hline \multicolumn{4}{|l|}{ Marital status } \\
\hline Never married & 39.1 & 20.1 & 31.1 \\
\hline Currently married & 45.1 & 31.0 & 35.3 \\
\hline Formerly married & 65.9 & 39.8 & 50.9 \\
\hline \multicolumn{4}{|l|}{ Educational attainment } \\
\hline No education & 49.4 & 29.0 & 33.1 \\
\hline Primary & 44.7 & 31.4 & 37.1 \\
\hline Secondary & 41.7 & 33.7 & 40.5 \\
\hline University & 66.1 & 73.4 & 66.4 \\
\hline
\end{tabular}

$\overline{{ }^{13} \text { Chambers R, Conway G. }}$ 1992. Sustainable rural livelihoods: Practical concepts for the 21 st century, Brighton UK: Institute of Development Studies 
Four percent of respondents first engaged in paid work before the age of 10, and 23 percent first worked before the age of 15 (Table 6.2). Early entry into paid work is more common among rural women than urban women. Among working women, urban women spend more hours in paid work than do rural women. At the same time, the study did not collect data on the hours spent on unpaid work, which could consume a significant amount of rural women's time.

On average, urban women earned nearly double the earnings than did rural women; mean monthly earnings among urban women was 418 Birr, compared to 220 Birr per month among rural women.

TABLE 6.2 Livelihoods: Age at first work, hours devoted to paid work, type of work and earnings from paid work, by type of place of residence

\begin{tabular}{|c|c|c|c|}
\hline Characteristic & Urban $(n=3,241)$ & Rural $(n=5,140)$ & All $(n=8,381)$ \\
\hline \multicolumn{4}{|l|}{ Age first worked for pay } \\
\hline Less than 10 years & 3.1 & 4.7 & 3.9 \\
\hline 10 to 14 years & 13.8 & 23.6 & 18.7 \\
\hline 15 to 19 years & 43.3 & 48.6 & 46.0 \\
\hline Age $20+$ & 39.8 & 23.1 & 31.4 \\
\hline Mean age first worked for pay & 17.9 & 16.2 & 17.1 \\
\hline \multicolumn{4}{|l|}{ Hours spent in paid work (last week) } \\
\hline 1 to 20 hours & 23.7 & 43.4 & 32.5 \\
\hline 21 to 40 hours & 23.3 & 39.1 & 30.3 \\
\hline 41 to 60 hours & 30.7 & 15.9 & 24.1 \\
\hline $60+$ hours & 22.3 & 1.6 & 13.1 \\
\hline Mean hours spend in paid work in the last week & 42.9 & 25.9 & 35.4 \\
\hline \multicolumn{4}{|l|}{ Amount earned in last month } \\
\hline$<100$ Birr / \$7.50 & 20.9 & 35.3 & 27.2 \\
\hline 100 to $299 \operatorname{Birr}(\$ 7.50$ to $\$ 23.00)$ & 36.3 & 38.1 & 37.1 \\
\hline 300 to 499 Birr ( $\$ 23.10$ to $\$ 38.40$ ) & 18.6 & 17.5 & 18.1 \\
\hline 500 to 699 Birr ( $\$ 38.50$ to $\$ 53.75)$ & 8.6 & 5.1 & 7.1 \\
\hline 700 Birr or more ( $\$ 54$ or more) & 15.6 & 4.0 & 10.5 \\
\hline Mean amount earned in the last month (Birr) & $418(\$ 32)$ & $220(\$ 17)$ & $331(\$ 25)$ \\
\hline \multicolumn{4}{|l|}{ Current paid work* } \\
\hline Petty trade & 22.4 & 20.6 & 21.5 \\
\hline Farmer, poultry keeper, etc. & 2.4 & 33.5 & 17.2 \\
\hline Domestic worker, cleaner, nanny, etc. & 22.6 & 2.9 & 13.2 \\
\hline Construction, porter, daily laborer & 10.0 & 14.6 & 12.2 \\
\hline Small scale food or drink production & 12.1 & 12.4 & 12.2 \\
\hline Professional, teacher & 12.3 & 2.9 & 7.8 \\
\hline Salesperson, office assistant, messenger & 5.0 & 0.3 & 2.8 \\
\hline Waitress, waiter, bartender & 3.9 & 0.1 & 2.1 \\
\hline Hairdresser, dressmaker, tailor & 3.7 & 0.1 & 2.1 \\
\hline Trades (mechanic, carpenter, plumber, mason, electrician) & 1.3 & 1.6 & 1.5 \\
\hline Sex worker & 0.2 & 0.0 & 0.1 \\
\hline
\end{tabular}


The most common paid work that women engaged in was petty trade (22 percent), followed by farming (17 percent), domestic worker/cleaner (13 percent), daily laborer (12 percent) and small scale food or drink production (12 percent). Patterns of worked roles differed for urban and rural areas. A significant proportion of rural women were in farming (34 percent) while 23 percent of working urban women were in domestic worker/cleaning.

Table 6.3 shows the mean earnings and hours worked by type of profession. The lowest paid forms of work among respondents were waitresses (mean 178 Birr/US \$13 per month), domestic workers (mean 191 Birr/ US $\$ 14$ per month), and construction/daily laborers (mean 228 Birr/US $\$ 17$ per month). The most highly paid forms of work were those working in shops (502 Birr/US $\$ 37$ per month), sex workers (781 Birr/US $\$ 58$ per month), and professionals (932 Birr/US \$69 per month).

TABLE 6.3 Livelihoods: Mean earning and hours worked in the last week, by type of work

\begin{tabular}{|c|c|c|}
\hline & $\begin{array}{l}\text { Mean earning in the last } \\
\text { month (Birr*) }\end{array}$ & $\begin{array}{c}\text { Mean hours worked in las } \\
\text { week }\end{array}$ \\
\hline Waitress, waiter, bartender & 178 Birr / US \$ 13 & 40 \\
\hline Domestic worker, cleaner, nanny, etc. & 191 Birr / US \$ 14 & 44 \\
\hline Construction, porter, daily laborer & 228 Birr / US \$ 17 & 33 \\
\hline Farmer, poultry keeper, etc. & 252 Birr / US \$ 19 & 27 \\
\hline Small scale food or drink production & 267 Birr / US \$ 20 & 31 \\
\hline Petty trade & 292 Birr / US \$ 22 & 34 \\
\hline Hairdresser, dressmaker, tailor & 324 Birr / US \$ 24 & 41 \\
\hline Trades (mechanic, carpenter, plumber, mason, electrician) & 383 Birr / US \$ 28 & 44 \\
\hline Salesperson, office assistant, messenger & 502 Birr / US \$ 37 & 51 \\
\hline Sex worker & 781 Birr / US \$ 58 & 43 \\
\hline Professional, teacher & 932 Birr / US \$ 69 & 38 \\
\hline
\end{tabular}

* US \$1 = 13.5 Ethiopian Birr

Education attainment was associated with earning levels, especially at the secondary level. Women with no education earned an average of 216 Birr per month; those with 1 to 4 years of education earned an average of 193 Birr; and those with 5 to 8 years of education earned an average of 287 Birr per month. Women with 9 or more years of education earned an average of 706 Birr per month, considerably more than women with only a primary level of education.

Only 13 percent of working women earned in-kind payment, such as food or shelter, with rural women more likely to receive in-kind payment (19 percent) compared to urban women ( 7 percent). Most in-kind payment was in the form of food; 17 percent of rural women and 5 percent of urban women reported receiving food as partial payment for their work.

\subsection{SKILLS TRAINING \& MICRO-CREDIT}

Ten percent of urban women and less than one percent of rural women have received vocational or skills training (Table 6.4). The most common type of training received was tailoring (10 percent), accounting (10 percent), computer ( 9 percent) and hair and beauty ( 8 percent). The majority of trainees have not put the skills to use (64 percent). The main reason given for not applying their skills was not being able to find a job (68 percent), having no start-up capital (18 percent), not having place to locate the business ( 8 percent) and not knowing what to do or how to start (5 percent) (Table 6.4).

Only 2 percent of women have received entrepreneurship or business training ( 3 percent of urban women and $<1$ percent of rural women). Nearly half of the women who have received the training have never put the skills to use (44 percent), with the main reasons being lack of start-up capital ( 65 percent), not being able to find a job (12 percent) and no knowing how to begin or go about it (11 percent). 
TABLE 6.4 Livelihoods: Vocational and entrepreneurship training, by type of place of residence

\begin{tabular}{|c|c|c|c|}
\hline Characteristic & Urban $(n=3,241)$ & Rural $(n=5,140)$ & All $(n=8,381)$ \\
\hline Ever attended vocational training & 9.9 & 0.7 & 4.4 \\
\hline \multicolumn{4}{|l|}{ Put vocational training skills to use $\mathrm{e}^{1}$} \\
\hline Yes & 33.0 & 82.3 & 35.9 \\
\hline No & 67.0 & 17.7 & 64.1 \\
\hline \multicolumn{4}{|l|}{ Reason for not putting vocational training to use } \\
\hline Could not find a job & 67.8 & 77.0 & 68.0 \\
\hline No start-up capital & 17.9 & 23.0 & 18.0 \\
\hline No place to locate the business & 8.5 & 0.0 & 8.3 \\
\hline Do not know how to start & 5.8 & 0.0 & 5.7 \\
\hline Ever received entrepreneurship/business training & 2.9 & 0.8 & 1.6 \\
\hline \multicolumn{4}{|l|}{ Put entrepreneurship/business training skills to use ${ }^{1}$} \\
\hline Yes & 52.4 & 66.0 & 56.3 \\
\hline No & 47.6 & 34.0 & 43.7 \\
\hline \multicolumn{4}{|c|}{ Reason for not putting entrepreneurship training to use ${ }^{1}$} \\
\hline No start-up capital & 72.0 & 34.1 & 64.7 \\
\hline Could not find a job & 11.2 & 17.0 & 12.2 \\
\hline Do not know how to start & 2.3 & 45.3 & 10.7 \\
\hline Found another job/ type of work & 5.8 & 0.0 & 4.7 \\
\hline Other ${ }^{2}$ & 8.7 & 3.6 & 7.7 \\
\hline
\end{tabular}

Six percent of respondents have been recipients of micro-credit to start or expand businesses (5 percent of urban respondents and 6 percent of rural respondents) (Table 6.5). Most micro-loans were given as groupbased loans (58 percent). Loan sizes varied by place of residence. Urban recipients received an average of 2,057 Birr/US $\$ 152$ on credit, whereas rural women received an average of 1,718 Birr/US \$127. Some respondents reported using at least part of the loan for reasons other than intended. Twelve percent of recipients reported that they, themselves, used funds for reasons other than business, and 6 percent reported other people known to them used the funds for other reasons. When asked who had mis-used the microcredit funds, the most common response was one's spouse (54 percent). The most common mis-use of micro-credit funds was for the purchase of food (48 percent).

Most respondents were still paying off their loans (67 percent) while only 5 percent admitted to having defaulted on their loans. When asked whether the micro-loan had improved, worsened or made no impact on their household situation, 81 percent reported that their situation had been improved and 15 percent reported no change in their circumstances. 
TABLE 6.5 Livelihoods: Experience with micro-credit, by type of place of residence

\begin{tabular}{|c|c|c|c|}
\hline Characteristic & Urban $(n=3,241)$ & Rural $(n=5,140)$ & All $(n=8,381)$ \\
\hline Ever received micro-credit & 4.6 & 6.4 & 5.7 \\
\hline \multicolumn{4}{|l|}{ Individual or group-based loan } \\
\hline Individual & 32.0 & 46.3 & 41.7 \\
\hline Group based & 68.0 & 53.7 & 58.3 \\
\hline \multicolumn{4}{|l|}{ Amount of micro-loan } \\
\hline Less than 1000 Birr & 20.9 & 19.6 & 20.0 \\
\hline 1000 to 1999 Birr & 25.7 & 44.5 & 38.5 \\
\hline 2000 to 2999 Birr & 24.6 & 25.4 & 25.2 \\
\hline $3000+$ Birr & 28.8 & 10.5 & 16.3 \\
\hline Amount of micro-loan (mean) & 2,057 Birr & 1,719 Birr & 1,823 Birr \\
\hline \multicolumn{4}{|c|}{ Some of the loan was used for reasons other than intended } \\
\hline By respondent & 12.6 & 12.7 & 12.7 \\
\hline By person known to respondent & 7.9 & 5.6 & 6.4 \\
\hline \multicolumn{4}{|l|}{ Status of micro-credit } \\
\hline Paid off the loan & 31.4 & 26.1 & 27.8 \\
\hline Still paying off the loan & 64.5 & 68.2 & 67.0 \\
\hline Defaulted on the loan & 4.1 & 5.7 & 5.2 \\
\hline \multicolumn{4}{|l|}{ Perceived impact of micro-credit } \\
\hline Improved situation & 76.2 & 82.9 & 80.8 \\
\hline Worsened situation & 7.2 & 3.2 & 4.6 \\
\hline Had no impact on situation & 16.6 & 13.9 & 14.6 \\
\hline
\end{tabular}

\subsection{SAVINGS \& EXPENDITURE}

Nearly 14 percent of urban women and 8 percent of rural woman had personal cash savings stored for future use or emergencies (Table 6.6). Urban women had saved considerably more money than rural women. On average, urban women who were saving had put aside over 2,300 Birr/ US \$170, compared to rural women's average of 907 Birr/US $\$ 67$ in savings. Among savers, 43 percent of urban women had saved over 1000 Birr/ US $\$ 74$ compared to 22 percent of rural women.

Where savings was kept differed between urban and rural areas. The most common place for urban women to keep savings was in a bank (43 percent), followed by their homes (27 percent) or in an ekub/savings circle (20 percent). Among rural women, the majority kept their savings at home (61 percent) or in an ekub/savings circle (16 percent). Twelve percent of women reported keeping their savings with micro-finance institutions (MFIs). 
TABLE 6.6 Livelihoods: Percentage of women aged 15 to 49 having personal cash savings, by type of place of residence

\begin{tabular}{|c|c|c|c|}
\hline Characteristic & Urban $(n=3,241)$ & Rural $(n=5,140)$ & All $(n=8,381)$ \\
\hline Has personal cash savings & 13.9 & 7.7 & 10.2 \\
\hline \multicolumn{4}{|l|}{ Amount of savings } \\
\hline Less than 200 Birr & 20.7 & 30.8 & 25.4 \\
\hline 200 to 499 Birr & 21.5 & 29.1 & 25.0 \\
\hline 500 to 999 Birr & 14.4 & 18.3 & 16.2 \\
\hline $1000+$ Birr & 43.4 & 21.8 & 33.4 \\
\hline Amount of savings (mean) & 2,316 Birr & 907 Birr & 1,670 Birr \\
\hline \multicolumn{4}{|l|}{ Where savings are kept ${ }^{1}$} \\
\hline At home & 27.3 & 60.8 & 42.7 \\
\hline Bank & 42.7 & 9.3 & 27.4 \\
\hline Ekub / Savings circle & 20.0 & 15.6 & 17.9 \\
\hline Micro-finance institution (MFI) & 11.4 & 12.9 & 12.1 \\
\hline With friends or relatives & 4.0 & 2.6 & 3.4 \\
\hline Mobile bank & 0.7 & 0.1 & 0.4 \\
\hline
\end{tabular}

Table 6.7 shows the average household expenditure on the most common foods and other basic living requirements. As expected, urban households had a higher monthly expenditure than rural household and larger households spent more money than smaller households. Most expenditure was on food, especially teff (average 210 Birr per month) and other grains (average 178 Birr per month). On average, 86 percent of household expenditure was devoted to food, while an average of 60 percent of expenditure was devoted to teff or other grains, alone. Among the basic items mentioned, the lowest expenditure was on healthcare (average 16 Birr per month) and only modest expenditure was made on schooling costs (average 24 Birr per month).

TABLE 6.7: Livelihoods: Mean monthly household expenditure on basic items, by type of place of residence and number of household members (in Ethiopian Birr) ${ }^{1}$

\begin{tabular}{lccc|ccc}
\hline & \multicolumn{3}{c|}{ Type of place of residence } & \multicolumn{3}{c}{ Number of household members } \\
\cline { 2 - 6 } & Urban & Rural & All & $\mathbf{1}$ to $\mathbf{3}$ & $\mathbf{4}$ to $\mathbf{5}$ & $\mathbf{6 +}$ \\
\hline Teff & 309 & 143 & 210 & 167 & 203 & 250 \\
Other grains & 107 & 220 & 178 & 118 & 171 & 228 \\
Fruit \& vegetables & 57 & 35 & 43 & 37 & 42 & 48 \\
Coffee/tea & 35 & 27 & 30 & 25 & 31 & 33 \\
Meat & 47 & 11 & 25 & 21 & 24 & 27 \\
Sugar \& salt & 36 & 19 & 26 & 23 & 25 & 29 \\
Oil/butter & 66 & 23 & 39 & 36 & 40 & 42 \\
Cooking fuel & 41 & 7 & 20 & 17 & 21 & 21 \\
School related costs & 56 & 5 & 24 & 18 & 24 & 28 \\
Transport \& communications & 42 & 3 & 18 & 15 & 18 & 19 \\
Rent, repair, maintenance & 57 & 3 & 23 & 34 & 24 & 15 \\
Healthcare & 28 & 10 & 16 & 16 & 15 & 17 \\
Total expenditure & $\mathbf{8 7 8}$ & $\mathbf{5 0 4}$ & $\mathbf{6 3 9}$ & $\mathbf{4 8 7}$ & $\mathbf{6 1 8}$ & $\mathbf{7 4 1}$ \\
\hline 1US \$1 = 13.5 Ethiopian Birr & & & & & &
\end{tabular}




\section{Chapter Seven: Alcohol \& Chat (Khat)}

\subsection{ALCOHOL}

Two thirds of female respondents report that they never drink alcohol and relatively few (6 percent) drink on a regular basis, two or more times per week (Table 7.1). Ever married women are more likely to be consumers of alcohol compared to the never married, which is probably also associated with the age of respondents in these categories. Regions with the largest percentage of women who abstain from alcohol are SNNPR (97 percent) and Afar (97 percent); regions with the lowest percentage of abstainers were Tigray (31 percent) and Amhara (54 percent). Eleven percent of Amhara women and 10 percent of women from BeneshangulGumuz drank twice or more in a week. Urban women are more likely to abstain from alcohol (88 percent) compared to rural women (69 percent); rural women are more likely to consume alcohol two or more times a week, compared to urban women.

TABLE 7.1: Alcohol: Percentage of women aged 15 to 49 who drink alcohol, by selected characteristics $(n=8,396)$

\begin{tabular}{|c|c|c|c|c|}
\hline & Never & Monthly or less & $\begin{array}{l}2 \text { to } 4 \text { times a } \\
\text { month }\end{array}$ & $2+$ times per week \\
\hline All respondents & 68.8 & 13.8 & 11.7 & 5.7 \\
\hline \multicolumn{5}{|l|}{ Age group } \\
\hline 15 to 19 & 75.9 & 12.4 & 8.6 & 3.1 \\
\hline 20 to 29 & 69.0 & 12.8 & 12.4 & 5.8 \\
\hline 30 to 39 & 66.0 & 13.9 & 13.1 & 7.0 \\
\hline 40 to 49 & 61.1 & 19.0 & 12.8 & 7.1 \\
\hline \multicolumn{5}{|l|}{ Marital status } \\
\hline Never married & 82.8 & 8.3 & 7.4 & 1.5 \\
\hline Currently married & 65.9 & 14.7 & 12.5 & 6.9 \\
\hline Divorced/separated/widowed & 61.3 & 18.5 & 14.5 & 5.7 \\
\hline \multicolumn{5}{|l|}{ Region } \\
\hline Tigray & 31.1 & 33.3 & 32.4 & 3.2 \\
\hline Afar & 96.8 & 2.8 & 0.0 & 0.4 \\
\hline Amhara & 54.3 & 17.0 & 17.6 & 11.1 \\
\hline Oromiya & 85.5 & 10.2 & 2.5 & 1.8 \\
\hline Benshangul Gumuz & 69.1 & 10.1 & 10.6 & 10.2 \\
\hline SNNPR & 98.5 & 0.5 & 0.2 & 0.8 \\
\hline Addis Ababa & 89.2 & 9.7 & 0.8 & 0.3 \\
\hline \multicolumn{5}{|l|}{ Type of place of residence } \\
\hline Urban & 88.4 & 8.2 & 2.4 & 1.0 \\
\hline Rural & 68.8 & 13.8 & 11.7 & 5.7 \\
\hline \multicolumn{5}{|l|}{ Educational attainment } \\
\hline No education & 68.9 & 14.3 & 10.9 & 5.9 \\
\hline Primary & 83.6 & 8.4 & 5.9 & 2.1 \\
\hline Secondary & 87.5 & 8.8 & 3.0 & 0.7 \\
\hline University & 86.1 & 10.5 & 3.3 & 0.1 \\
\hline
\end{tabular}


Those reporting alcohol consumption (non-abstainers) were asked the number of days they consumed alcohol in the last month and the amount of money spent on alcohol (Table 7.2). On average, rural women drank alcohol on 7 days in the last month while urban women drank on an average of 3 days in the last month. At the same time, urban women spent significantly more on alcohol than did rural women; urban women spent an average of 4 Birr (US $\$ 0.30$ ) compared to rural women spending an average of less than $1 \operatorname{Birr}$ (US \$0.08). This is probably related to the fact that much of the alcohol consumed in rural areas of the country is produced in the home.

TABLE 7.2: Alcohol: Percentage of women drinkers aged 15 to 49 who drank alcohol by frequency of alcohol consumption in the last month, by type of place of residence $(n=2,056)$

\begin{tabular}{|c|c|c|c|}
\hline & Urban & Rural & All \\
\hline \multicolumn{4}{|l|}{ Number of days drank in the last month* } \\
\hline None & 25.7 & 6.2 & 10.0 \\
\hline 1 to 3 days & 52.0 & 38.7 & 41.3 \\
\hline 4 to 7 days & 13.0 & 21.8 & 20.1 \\
\hline 8 to 12 days & 6.9 & 13.9 & 12.5 \\
\hline $13+$ days & 2.4 & 19.4 & 16.1 \\
\hline Mean number of days consumed alcohol (last month; all women) & 0.3 & 2.1 & 1.4 \\
\hline Mean number of days consumed alcohol (last month; alcohol consumers only)* & 2.6 & 6.8 & 6.0 \\
\hline Money spent in the last week on alcohol (in Ethiopian Birr) & 4 Birr & $<1$ Birr & 1 Birr \\
\hline
\end{tabular}

\subsection{CHAT / KHAT}

Three percent of women in the sample had ever chewed chat with roughly equal proportions of women in urban and rural areas having had the experience (Table 7.3). Older women in the sample were more likely to have experimented with chat compared to young women. Among women aged 40 to 49, 5 percent had tried chat compared to 2 percent of young women aged 15 to 19 .

There was considerable regional variation in the extent to which women had tried chat. Sixteen percent of Afar women and 6 percent of Oromiya women had tried chat. By comparison, not one respondent from Tigray reported having tried chat and only 1 to 2 percent of women in Addis Ababa and Amhara had tried it. 
TABLE 7.3 Chat: Percentage of women aged 15 to 49 years who ever chewed chat, by type of place of residence and selected characteristics

\begin{tabular}{lccc}
\hline & Urban $(n=3,250)$ & Rural $(n=5,146)$ & All $(n=8,396)$ \\
\hline Ever chewed chat (all respondents) & 3.3 & 3.5 & 3.4
\end{tabular}

Age group

$\begin{array}{llll}15 \text { to } 19 & 1.4 & 1.8 & 1.6 \\ 20 \text { to } 29 & 4.1 & 3.9 & 4.0 \\ 30 \text { to } 39 & 2.5 & 3.9 & 3.4 \\ 40 \text { to } 49 & 7.0 & 4.3 & 5.2\end{array}$

\section{Marital status}

$\begin{array}{llll}\text { Never Married } & 1.2 & 1.7 & 1.5 \\ \text { Currently Married } & 4.5 & 4.1 & 4.2 \\ \text { Divorced/separated/widowed } & 6.6 & 2.8 & 4.4\end{array}$

\section{Region}

$\begin{array}{lccc}\text { Tigray } & 0.0 & 0.0 & 0.0 \\ \text { Afar } & 21.1 & 11.7 & 15.9 \\ \text { Amhara } & 2.4 & 1.2 & 1.5 \\ \text { Oromiya } & 2.4 & 8.2 & 6.3 \\ \text { Benshangul Gumuz } & 4.7 & 3.1 & 3.4 \\ \text { SNNPR } & 5.1 & 1.5 & 2.8 \\ \text { Addis Ababa } & 1.4 & - & 1.4\end{array}$

Educational attainment

\begin{tabular}{llll} 
No education & 5.8 & 3.7 & 4.1 \\
Primary & 4.1 & 3.0 & 3.5 \\
Secondary & 4.2 & 2.1 & 1.3 \\
University & 0.0 & 0.0 & 0.0 \\
\hline
\end{tabular}

Among females who have tried chat, a significant proportion (71 percent) have consumed it in the last month (Table 7.4). Nineteen percent of women who have tried it consider themselves addicted to it. When asked where they consume it, the most common place is in the home (83 percent). On average, consumers of chat spent 12 Birr (nearly US \$1) on chat in the week prior to survey. Considering the entire sample of women, 2 percent have chewed chat in the last month and less than 1 percent consider themselves addicted to it. 
TABLE 7.4 Chat: Percentage of female chat users who chewed in the last month, and frequency of chat consumption, by type of place of residence and selected characteristics

\begin{tabular}{|c|c|c|c|}
\hline & Urban $(n=182)$ & Rural (n=222) & All $(n=404)$ \\
\hline Chewed chat in the last month (all) & 2.4 & 2.4 & 2.4 \\
\hline Chewed chat in the last month (ever users*) & 72.1 & 70.5 & 71.1 \\
\hline Considers oneself addicted to chat (all) & 0.4 & 0.8 & 0.6 \\
\hline Considers oneself addicted to chat (ever users*) & 12.0 & 22.7 & 18.6 \\
\hline
\end{tabular}

No of days per week chat is chewed

$\begin{array}{lccc}\text { None } & 28.4 & 29.4 & 29.0 \\ 1 \text { to } 2 \text { days } & 49.9 & 49.7 & 49.8 \\ 3 \text { to } 5 \text { days } & 15.4 & 11.2 & 12.8 \\ 6 \text { to } 7 \text { days } & 6.3 & 9.7 & 8.4\end{array}$

Where chat is typically chewed

$\begin{array}{lccc}\text { At home } & 89.7 & 78.7 & 83.0 \\ \text { At friend's home } & 6.3 & 6.5 & 6.4 \\ \text { At work } & 0.6 & 5.6 & 3.6 \\ \text { In neighborhood/street } & 0.7 & 2.7 & 1.9 \\ \text { Chat shop } & 2.3 & 0.7 & 1.3 \\ \text { Other } & 0.3 & 5.8 & 3.7\end{array}$

Money spent on chat in last week (Birr) 


\section{Chapter Eight: Female Genital Mutilation/Cutting}

\subsection{PREVALENCE OF FGM/C}

Overall, 70 percent of women are circumcised, which is comparable to findings from the Demographic and Health Survey for Ethiopia (2005). Sixty-three percent of urban respondents and 74 percent of rural respondents reporting being circumcised (Table 8.1). The most common form of female genital cutting/ mutilation (FGM/C) is clitoridectomy (65 percent of circumcised women). At the same time, a significant proportion (29 percent) do not know the type of FGM/C they received.

There appears to be a decline in the rates of circumcision. Among women aged 40 to 49, 80 percent are circumcised compared to 58 percent of young women aged 15 to 19. Regions with the highest rates of FGM/C are Afar (95 percent), SNNPR (91 percent), and Oromiya (89 percent). Tigray and Amhara have the lowest rates of FGM/C (40 percent in Tigray; 54 percent in Amhara). In Afar, the region of the highest FGM/C prevalence, the most extreme form is practiced with 34 percent of circumcised women reporting being infibulated.

TABLE 8.1: Female genital mutilation/cutting: Percentage of women aged 15 to 49 who are circumcised, by type of circumcision and selected characteristics

\begin{tabular}{|c|c|c|c|c|c|c|c|c|}
\hline \multirow[t]{2}{*}{ Characteristic } & \multicolumn{3}{|c|}{ Percentage of females circumcised } & \multicolumn{5}{|c|}{ Type of circumcision } \\
\hline & $\begin{array}{c}\text { Urban } \\
(n=3,240)\end{array}$ & $\underset{(n=5,143)}{\text { Rural }}$ & $\begin{array}{c}\text { Total } \\
(n=8,383)\end{array}$ & $\begin{array}{l}\text { Clitori- } \\
\text { dectomy }\end{array}$ & Excision & $\begin{array}{l}\text { Infibu- } \\
\text { lation }\end{array}$ & $\begin{array}{l}\text { Don't } \\
\text { know }\end{array}$ & Total \\
\hline All respondents & 62.8 & 74.4 & 69.8 & 64.8 & 3.8 & 2.2 & 29.2 & 100.0 \\
\hline \multicolumn{9}{|l|}{ Age group } \\
\hline 15 to 19 & 48.9 & 65.7 & 58.4 & 62.8 & 3.1 & 2.1 & 32.0 & 100.0 \\
\hline 20 to 29 & 63.2 & 75.0 & 70.0 & 65.7 & 3.8 & 2.4 & 28.1 & 100.0 \\
\hline 30 to 39 & 74.8 & 78.3 & 77.0 & 65.8 & 4.3 & 2.5 & 27.4 & 100.0 \\
\hline 40 to 49 & 76.5 & 81.2 & 79.8 & 65.0 & 3.8 & 1.8 & 29.4 & 100.0 \\
\hline \multicolumn{9}{|l|}{ Region } \\
\hline Tigray & 36.2 & 41.2 & 40.3 & 73.1 & 1.7 & 0.0 & 25.2 & 100.0 \\
\hline Afar & 92.3 & 96.3 & 94.5 & 36.6 & 10.6 & 33.6 & 19.2 & 100.0 \\
\hline Amhara & 30.7 & 61.7 & 53.7 & 46.3 & 2.7 & 0.3 & 50.7 & 100.0 \\
\hline Oromiya & 78.7 & 94.4 & 89.1 & 73.8 & 5.3 & 0.1 & 20.8 & 100.0 \\
\hline Benishangul Gumuz & 53.4 & 69.7 & 67.1 & 81.0 & 3.9 & 0.0 & 15.1 & 100.0 \\
\hline SNNP & 86.3 & 93.2 & 90.6 & 93.1 & 1.9 & 0.1 & 4.9 & 100.0 \\
\hline Addis Ababa & 61.9 & - & 61.9 & 45.4 & 2.1 & 0.1 & 52.4 & 100.0 \\
\hline \multicolumn{9}{|l|}{ Educational attainment } \\
\hline No education & 67.5 & 75.2 & 73.7 & 63.2 & 4.3 & 3.3 & 29.2 & 100.0 \\
\hline 1 to 4 years & 66.9 & 75.2 & 72.3 & 70.3 & 4.2 & 1.6 & 23.9 & 100.0 \\
\hline 5 to 8 years & 67.5 & 70.7 & 68.9 & 68.4 & 2.9 & 0.9 & 27.8 & 100.0 \\
\hline $9+$ years & 55.9 & 69.7 & 57.7 & 62.9 & 2.3 & 0.7 & 34.1 & 100.0 \\
\hline
\end{tabular}


Table 8.2 shows the circumstances of FGM/C among all circumcised women and among circumcised women in Afar region. Many respondents did not know the circumstances of their circumcision, perhaps because it occurred at very young ages for many respondents. Most circumcisions took place during infancy: 51 percent of all circumcised women and 81 percent of Afar women were circumcised before their first birthday. Mothers were reportedly the main decision-makers regarding the circumcision; 78 percent of women reported that their mothers contributed to the decision. After that, fathers were reportedly involved in the decision to circumcise (56 percent). Most circumcisions took place in a home (77 percent) and were performed by a traditional circumciser (62 percent).

TABLE 8.2: Female genital mutilation/cutting: Age at FGM/C, decision-maker, and profile of circumciser, by type of place of residence and in Afar region

\begin{tabular}{|c|c|c|c|c|c|c|}
\hline \multirow[t]{2}{*}{ Characteristic } & \multicolumn{3}{|c|}{ All circumcised women } & \multicolumn{3}{|c|}{ Circumcised women, Afar region } \\
\hline & $\begin{array}{c}\text { Urban } \\
(n=2,186)\end{array}$ & $\begin{array}{c}\text { Rural } \\
(n=3,814)\end{array}$ & $\begin{array}{c}\text { Total } \\
(n=6,000)\end{array}$ & $\begin{array}{c}\text { Urban } \\
(n=480)\end{array}$ & $\begin{array}{c}\text { Rural } \\
(n=681)\end{array}$ & $\begin{array}{c}\text { Total } \\
(n=1,161)\end{array}$ \\
\hline \multicolumn{7}{|l|}{ Age at circumcision } \\
\hline Less than 1 year & 51.1 & 51.7 & 51.4 & 85.4 & 77.6 & 81.0 \\
\hline 1 to 5 years & 20.4 & 10.9 & 14.3 & 3.9 & 6.7 & 5.5 \\
\hline 6 to 10 years & 23.7 & 23.8 & 23.8 & 8.3 & 6.0 & 7.0 \\
\hline Over age 10 & 4.8 & 13.6 & 10.5 & 2.4 & 9.7 & 6.5 \\
\hline \multicolumn{7}{|l|}{ Who decided upon circumcision ${ }^{1}$} \\
\hline Mother & 74.6 & 74.9 & 74.8 & 90.6 & 88.5 & 89.4 \\
\hline Father & 57.3 & 54.5 & 55.5 & 78.5 & 68.9 & 73.1 \\
\hline Grandmother/aunt & 6.6 & 4.7 & 5.4 & 2.5 & 2.6 & 2.5 \\
\hline Respondent/ self & 1.3 & 4.4 & 3.3 & 0.0 & 0.6 & 0.3 \\
\hline Other & 3.7 & 4.9 & 4.4 & 0.8 & 0.9 & 0.8 \\
\hline Don't know & 18.4 & 15.6 & 16.6 & 6.3 & 6.6 & 6.5 \\
\hline \multicolumn{7}{|l|}{ Profile of circumciser } \\
\hline Traditional circumciser & 65.4 & 60.2 & 62.0 & 55.9 & 59.2 & 57.8 \\
\hline Traditional birth attendant & 5.5 & 5.1 & 5.3 & 10.7 & 10.3 & 10.5 \\
\hline Relative & 1.8 & 6.6 & 4.9 & 1.9 & 1.9 & 1.9 \\
\hline Other & 2.3 & 1.8 & 2.0 & 0.0 & 0.3 & 0.1 \\
\hline Don't know & 25.0 & 26.3 & 25.8 & 31.5 & 28.3 & 29.7 \\
\hline \multicolumn{7}{|l|}{ Context of circumcision } \\
\hline Alone & 56.7 & 55.6 & 56.0 & 74.9 & 62.9 & 68.0 \\
\hline In group & 33.8 & 36.2 & 35.4 & 17.2 & 25.3 & 21.9 \\
\hline Don't know & 9.5 & 8.2 & 8.6 & 7.9 & 11.8 & 10.1 \\
\hline \multicolumn{7}{|l|}{ Location of circumcision } \\
\hline Home & 70.1 & 62.7 & 65.4 & 71.7 & 59.9 & 65.0 \\
\hline $\begin{array}{l}\text { Another home or home of } \\
\text { circumciser }\end{array}$ & 7.4 & 14.0 & 11.7 & 10.1 & 6.9 & 8.4 \\
\hline Other ${ }^{2}$ & 3.5 & 2.8 & 3.0 & 4.7 & 13.2 & 9.4 \\
\hline Don't know & 19.0 & 20.5 & 19.9 & 13.5 & 20.0 & 17.2 \\
\hline
\end{tabular}


Six percent of circumcised women reported that they had experienced a problem as a result of the procedure. The extent to which women reported problems varied by the type of circumcision they had received. Five percent of women with clitoridectomy reported problems; 8 percent of excised women reported problems and 27 percent of infibulated women experienced problems. Among women reporting associated problems, the most common problems were pain during urination (59 percent), pain during the healing process (41 percent), difficulty during childbirth (20 percent) and pain during menstruation (10 percent).

\subsection{ATTITUDES TOWARD FGM/C}

Over half of the circumcised women in the sample oppose that they were circumcised (57 percent). Urban women who were circumcised are more likely to oppose their circumcision ( 80 percent) compared to rural women who experienced the practice (45 percent). Younger women were more likely to oppose their circumcision with 62 percent of girls 15 to 19 opposing their own circumcision compared to 47 percent of women aged 40 to 49 opposing it. In Afar, considerably fewer respondents oppose their own circumcision (40 percent). Among Afar girls 15 to 19, 49 percent opposed their circumcision compared to 28 percent among Afar women aged 40 to 49.

Among supporters of FGM/C, the main reason given was that it is the custom and tradition (83 percent). By comparison, far fewer respondents cited the marriage prospects $(20$ percent), religion (16 percent) and cleanliness (16 percent). In Afar, however, 46 percent of respondents cited religion as a reason for supporting the practice.

Among those that opposed the practice, most respondents cited the medical complications associated with the practice (49 percent) and the fact that it is illegal in Ethiopia (45 percent). In Afar, 45 percent of respondents believed the practice has lost its cultural significance.

TABLE 8.3: Female genital mutilation/cutting: Percentage of women supporting or opposing their own FGM/C and reasons, by type of place of residence and in Afar region

\begin{tabular}{|c|c|c|c|c|c|c|}
\hline \multirow[t]{2}{*}{ Characteristic } & \multicolumn{3}{|c|}{ All circumcised women } & \multicolumn{3}{|c|}{ Circumcised women, Afar region } \\
\hline & $\begin{array}{c}\text { Urban } \\
(n=2,186)\end{array}$ & $\begin{array}{c}\text { Rural } \\
(n=3,814)\end{array}$ & $\begin{array}{c}\text { Total } \\
(n=6,000)\end{array}$ & $\begin{array}{c}\text { Urban } \\
(n=2,186)\end{array}$ & $\begin{array}{c}\text { Rural } \\
(n=3,814)\end{array}$ & $\begin{array}{c}\text { Total } \\
(n=1,161)\end{array}$ \\
\hline \multicolumn{7}{|l|}{ Support or oppose own circumcision } \\
\hline Support & 20.5 & 55.1 & 42.7 & 43.3 & 73.0 & 60.1 \\
\hline Oppose & 79.5 & 44.9 & 57.3 & 56.7 & 27.0 & 39.9 \\
\hline \multicolumn{7}{|l|}{ Reason for support ${ }^{1}$} \\
\hline Custom and tradition demand & 78.5 & 83.6 & 82.7 & 87.0 & 85.8 & 86.2 \\
\hline Better marriage perspectives & 17.4 & 20.1 & 19.6 & 2.9 & 3.4 & 3.2 \\
\hline Religion demands & 16.7 & 15.8 & 16.0 & 42.3 & 48.3 & 46.4 \\
\hline Cleanliness & 13.5 & 13.6 & 13.6 & 6.4 & 12.0 & 10.3 \\
\hline Prevents immorality & 7.0 & 2.9 & 3.6 & 0.8 & 3.6 & 2.7 \\
\hline Other & 10.3 & 9.7 & 9.8 & 7.8 & 13.6 & 11.7 \\
\hline \multicolumn{7}{|l|}{ Reasons for opposition ${ }^{1}$} \\
\hline Medical complication & 52.8 & 45.8 & 49.3 & 50.9 & 39.5 & 46.6 \\
\hline Illegal & 45.2 & 46.3 & 45.8 & 24.5 & 18.5 & 22.2 \\
\hline Tradition/lost significance & 40.1 & 37.3 & 38.7 & 46.2 & 41.8 & 44.5 \\
\hline Painful experience & 15.5 & 19.8 & 17.7 & 20.6 & 19.7 & 20.2 \\
\hline Against dignity of girls & 10.1 & 8.5 & 9.3 & 7.4 & 2.6 & 5.6 \\
\hline Prevents sexual satisfaction & 7.5 & 2.4 & 4.9 & 7.6 & 2.4 & 5.6 \\
\hline
\end{tabular}


Respondents were read a series of statements related to FGM/C and asked if they agree or disagree with the statement. Table 8.4 shows the percentage of respondents agreeing with statements on FGM/C. Nearly one third ( 28 percent) of respondents felt that a girl should be circumcised before she is married; in Afar, 45 percent of respondents felt a girl should be circumcised prior to marriage. About one quarter of respondents felt that an uncircumcised girl is a dishonor to her family, that boys prefer to marry circumcised girls, and their community expects the circumcision. Rural women were more likely to hold these beliefs compared to urban women; whereas over one third of rural women agreed with these statements, only about 10 percent of urban women agreed with them.

TABLE 8.4: Female genital mutilation/cutting: Personal opinions about FGM/C, by type of place of residence, and in Afar region

\begin{tabular}{|c|c|c|c|c|c|c|}
\hline \multirow[b]{2}{*}{ Percentage agreement with the statement } & \multicolumn{3}{|c|}{ All women } & \multicolumn{3}{|c|}{ Afar region only } \\
\hline & $\begin{array}{c}\text { Urban } \\
(n=3,239)\end{array}$ & $\begin{array}{c}\text { Rural } \\
(n=3,237)\end{array}$ & $\begin{array}{c}\text { Total } \\
(n=8,373)\end{array}$ & $\begin{array}{l}\text { Urban } \\
(n=521)\end{array}$ & $\begin{array}{c}\text { Rural } \\
(n=707)\end{array}$ & $\begin{array}{c}\text { Total } \\
(n=1,228)\end{array}$ \\
\hline A girl should undergo FGM/C before she is married & 10.3 & 39.2 & 27.7 & 25.7 & 59.7 & 44.6 \\
\hline $\begin{array}{l}\text { Not being circumcised is a dishonor to the girl's } \\
\text { family }\end{array}$ & 9.0 & 37.7 & 26.3 & 21.9 & 51.3 & 38.2 \\
\hline $\begin{array}{l}\text { Most boys in your community would not marry an } \\
\text { uncircumcised girl }\end{array}$ & 10.2 & 36.1 & 25.8 & 17.4 & 49.5 & 35.2 \\
\hline $\begin{array}{l}\text { Your community expects you to circumcise your } \\
\text { (future) daughters }\end{array}$ & 9.3 & 35.4 & 25.0 & 22.8 & 55.7 & 41.0 \\
\hline $\mathrm{FGM} / \mathrm{C}$ is required by your religion & 10.7 & 24.5 & 19.0 & 41.4 & 64.5 & 54.2 \\
\hline
\end{tabular}

Only about 1 in 5 respondents believe that FGM/C should continue and intend to circumcise their daughters in the future (Table 8.5). In contrast, 42 percent of women in Afar believe it should continue and intend to circumcise their daughters. Sixty-one percent of respondents have heard a media message related to FGM/C in the last year. While 12 percent of all women had heard a public pledge against FGM in the last year, only 2 percent of Afar women had heard such a pledge in the last year.

TABLE 8.5: Female genital mutilation/cutting: Future intentions regarding FGM/C and exposure to messages, by type of place of residence and in Afar region

\begin{tabular}{lccc|ccc}
\hline & \multicolumn{3}{c|}{ All women } & \multicolumn{3}{c}{ Afar region only } \\
\cline { 2 - 7 } & $\begin{array}{c}\text { Urban } \\
(\mathbf{n = 3 , 2 3 9 )}\end{array}$ & $\begin{array}{c}\text { Rural } \\
(\mathbf{n = 3 , 2 3 7 )}\end{array}$ & $\begin{array}{c}\text { Total } \\
(\mathbf{n}=\mathbf{8 , 3 7 3})\end{array}$ & $\begin{array}{c}\text { Urban } \\
(\mathbf{n}=\mathbf{3 , 2 3 9 )}\end{array}$ & $\begin{array}{c}\text { Rural } \\
(\mathbf{n}=\mathbf{3 , 2 3 7})\end{array}$ & $\begin{array}{c}\text { Total } \\
(\mathbf{n}=\mathbf{1 , 2 2 8})\end{array}$ \\
\hline Believe that FGM/C should continue & 7.7 & 32.6 & 22.7 & 22.6 & 57.3 & 41.8 \\
Will circumcise (future) daughter(s) & 6.6 & 31.8 & 21.8 & 22.2 & 57.7 & 41.9 \\
Had ever heard a message related to FGM/C & 78.2 & 50.0 & 61.2 & 69.2 & 48.3 & 57.7 \\
Has heard a public pledge against FGM/C in last year & 13.6 & 10.7 & 11.9 & 1.5 & 1.7 & 1.6 \\
\hline
\end{tabular}




\section{Chapter Nine: Marriage}

The legal age at marriage for both girls and boys is 18 in Ethiopia, and child marriage is defined as marriage before the age of 18 . While marriage is a transition that is nearly universally experienced, marriages that are too early may be associated with negative health and development outcomes.

\subsection{MARITAL STATUS}

The majority of respondents had ever been married (71 percent) (Table 9.1). However, 59 percent of respondents were married at the time of survey, 9 percent were divorced or separated, and 4 percent were widowed. As expected, the proportion of women who are married, divorced or widowed increases with age. Among those aged 15 to 19, 75 percent have never been married and 20 percent are currently married. Five percent of young women in this age group are already divorced or separated. Among women aged 40 to 49, only 2 percent have never been married, 68 percent are currently married, 13 percent are divorced or separated and 16 percent are widowed. The marital status of women varied considerably between urban and rural areas. Only 20 percent of rural women in the sample had never been married compared to 42 percent of urban women. Likewise, lower educational attainment was associated with a greater probability of ever having been married. Among those with no education, only 9 percent were never married compared to 60 percent of respondents with 9 or more years of education.

Median age at marriage was 17.8 (16.9 years among rural women and 19.9 among urban women).$^{14}$ Among ever-married respondents 7 percent were married before the age of 10 and 33 percent were married before the age of 15 . The majority of marriages ( 93 percent) were monogamous.

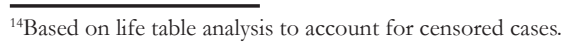


TABLE 9.1: Marriage: Current marital status of women aged 15 to 49 , by selected characteristics $(n=8,396)$

\begin{tabular}{|c|c|c|c|c|}
\hline & Never married & Currently married & $\begin{array}{c}\text { Divorced } \\
\text { /separated }\end{array}$ & Widowed \\
\hline All respondents & 29.0 & 58.8 & 8.5 & 3.7 \\
\hline \multicolumn{5}{|l|}{ Age group } \\
\hline 15 to 19 & 75.4 & 20.0 & 4.5 & 0.1 \\
\hline 20 to 29 & 22.4 & 69.3 & 7.6 & 0.7 \\
\hline 30 to 39 & 4.1 & 77.2 & 12.3 & 6.4 \\
\hline 40 to 49 & 2.3 & 68.2 & 13.1 & 16.4 \\
\hline \multicolumn{5}{|l|}{ Region } \\
\hline Tigray & 23.3 & 61.9 & 11.9 & 2.9 \\
\hline Afar & 19.2 & 65.9 & 10.5 & 4.4 \\
\hline Amhara & 22.8 & 61.3 & 13.0 & 2.9 \\
\hline Oromiya & 26.1 & 65.9 & 4.0 & 4.0 \\
\hline Benshangul Gumuz & 15.9 & 71.8 & 9.3 & 3.0 \\
\hline SNNP & 36.7 & 54.1 & 4.7 & 4.5 \\
\hline Addis Ababa & 49.5 & 39.0 & 7.0 & 4.5 \\
\hline \multicolumn{5}{|l|}{ Type of place of residence } \\
\hline Urban & 42.4 & 44.5 & 9.3 & 3.8 \\
\hline Rural & 20.3 & 68.1 & 8.0 & 3.6 \\
\hline \multicolumn{5}{|l|}{ Educational attainment } \\
\hline No education & 8.6 & 75.3 & 10.7 & 5.4 \\
\hline Primary & 46.8 & 44.2 & 7.1 & 1.9 \\
\hline Secondary & 59.7 & 34.6 & 4.3 & 1.4 \\
\hline University & 58.7 & 36.4 & 1.0 & 3.9 \\
\hline
\end{tabular}

Table 9.2 shows the percentage of respondents married by age 15 and age 18, among those aged 18 and above. Older respondents were more likely to have been married early compared to those who are younger, reflecting declines in the prevalence of early marriage. Whereas 40 percent of respondents aged 40 to 49 were married by their $15^{\text {th }}$ birthday, 14 percent of those aged 18 and 19 were married by this age. Respondents with no education were significantly more likely to experience early marriage, with 38 percent married by age 15 and 82 percent married by age 18. The highest rates of very early marriage occurred in Amhara region (52 percent married by age 15), followed by Beneshangul Gumuz (31 percent married by age 15) and Tigray (22 percent married by age 15). 
TABLE 9.2: Marriage: Percentage of respondents married by age 15 and 18, among respondents aged 18 and above, by selected characteristics $(n=8,396)$

\begin{tabular}{|c|c|c|}
\hline & Married by age 15 & Married by age 18 \\
\hline All respondents & 25.3 & 62.0 \\
\hline \multicolumn{3}{|l|}{ Age group } \\
\hline 18 to 19 & 14.4 & 38.1 \\
\hline 20 to 29 & 21.9 & 57.5 \\
\hline 30 to 39 & 29.3 & 72.2 \\
\hline 40 to 49 & 39.9 & 81.3 \\
\hline \multicolumn{3}{|c|}{ Type of place of residence } \\
\hline Urban & 13.7 & 40.2 \\
\hline Rural & 32.8 & 75.9 \\
\hline \multicolumn{3}{|l|}{ Region } \\
\hline Tigray & 21.7 & 73.6 \\
\hline Affar & 14.6 & 74.6 \\
\hline Amhara & 52.4 & 80.0 \\
\hline Oromiya & 11.4 & 54.9 \\
\hline Benishangul- Gumuz & 30.6 & 81.2 \\
\hline SNNPR & 11.7 & 51.6 \\
\hline Addis Ababa & 5.7 & 27.9 \\
\hline \multicolumn{3}{|l|}{ Educational attainment } \\
\hline No education & 37.7 & 82.3 \\
\hline Primary & 12.0 & 48.6 \\
\hline Secondary & 3.4 & 15.0 \\
\hline University & 3.9 & 6.0 \\
\hline
\end{tabular}

On average, married females were 7 years younger than their husbands (Table 9.3). The younger the girl was when she married, the larger the age difference with her spouse. Among girls married between the ages 10 to 14 , they were, on average 8 years younger than their spouse; among those married after age 20 , they were an average of 6 years younger than their spouse.

The majority of marriages (70 percent) were arranged, particularly in rural areas where 82 percent of marriages were arranged by families. As a result, many women did not know their husbands before marriage. Fifty-nine percent of rural women and 31 percent of urban women met their husband on the wedding day. The younger the girl when she was married, the more likely her marriage was arranged. Ninety-nine percent of girls married before age 10 and 90 percent of girls married between the ages of 10 to 14 had arranged marriages. Among girls married after age 20, 25 percent had arranged marriages.

Nearly half (44 percent) of women did not want to get married at the time they did. Likewise, the younger a girl was when she married, the more likely that her marriage was unwanted. Only 9 percent of girls married before age 10 wanted to marry at the time they did; 29 percent of girls married between the ages of 10 to 14 wanted to marry at that time. In contrast, 91 percent of girls who married after age 20 wanted the marriage at the time. 
TABLE 9.3: Marriage: Age at first marriage and context of marriage, by type of place of residence

\begin{tabular}{|c|c|c|c|}
\hline & Urban $(n=2,012)$ & Rural $(n=4,154)$ & All $(n=6,166)$ \\
\hline \multicolumn{4}{|l|}{ Age at first marriage } \\
\hline Before age 10 & 4.3 & 8.1 & 6.9 \\
\hline Age 10 to 14 & 17.5 & 29.4 & 25.6 \\
\hline Age 15 to 17 & 29.6 & 38.1 & 35.4 \\
\hline Age 18 to 20 & 27.9 & 19.9 & 22.5 \\
\hline Age $21+$ & 20.7 & 4.5 & 9.6 \\
\hline Median age at first marriage & 19.9 & 16.9 & 17.8 \\
\hline \multicolumn{4}{|l|}{ Age difference with spouse } \\
\hline Over 10 years younger & 22.7 & 16.2 & 18.3 \\
\hline 6 to 10 years younger & 37.7 & 42.3 & 40.8 \\
\hline 1 to 5 years younger & 37.2 & 39.8 & 38.9 \\
\hline Same age or older & 2.4 & 1.7 & 2.0 \\
\hline Mean age difference with spouse & 7.7 yrs younger & 7.2 yrs younger & 7.3 yrs younger \\
\hline \multicolumn{4}{|l|}{ Spouse had other wives } \\
\hline No & 93.1 & 93.2 & 93.2 \\
\hline Yes & 6.9 & 6.8 & 6.8 \\
\hline \multicolumn{4}{|l|}{ Chosen or arranged marriage } \\
\hline Arranged & 44.9 & 82.2 & 70.2 \\
\hline Chosen & 52.7 & 14.1 & 26.5 \\
\hline Abducted & 2.4 & 3.7 & 3.3 \\
\hline \multicolumn{4}{|l|}{ Consented to marriage } \\
\hline No & 24.0 & 44.8 & 38.2 \\
\hline Yes & 76.0 & 55.2 & 61.8 \\
\hline \multicolumn{4}{|c|}{ Length of time respondent knew spouse before marriage } \\
\hline Met on wedding day & 31.3 & 59.2 & 50.2 \\
\hline Less than one year & 26.1 & 17.2 & 20.0 \\
\hline One year or more & 34.2 & 11.5 & 18.8 \\
\hline Since childhood & 8.4 & 12.1 & 11.0 \\
\hline \multicolumn{4}{|l|}{ 'Wantedness' of marriage } \\
\hline Wanted to get married & 69.0 & 50.0 & 56.1 \\
\hline Did not want marriage or undecided & 31.0 & 50.0 & 43.9 \\
\hline
\end{tabular}




\subsection{MARITAL RELATIONS}

The vast majority of married women (96 percent) experienced first sex with their husband, mainly after marriage (91 percent) (Table 9.4). Only 4 percent of married women had premarital first sex (16 percent of urban women and 3 percent of rural women).

TABLE 9.4: Marriage: Timing of sexual initiation and marital sexual relations, by type of place of residence

\begin{tabular}{|c|c|c|c|}
\hline & Urban $(n=2,012)$ & Rural $(n=4,154)$ & All $(n=6,166)$ \\
\hline \multicolumn{4}{|l|}{ Sexual initiation and timing of marriage } \\
\hline Had first sex with spouse after marriage & 81.4 & 95.2 & 90.9 \\
\hline Had first sex with spouse before marriage/during engagement & 12.7 & 1.8 & 5.2 \\
\hline Had premarital sex with someone other than spouse & 5.9 & 3.0 & 3.9 \\
\hline \multicolumn{4}{|l|}{ Experienced sexual initiation before or after menarche } \\
\hline Before & 18.5 & 42.2 & 34.7 \\
\hline After & 81.5 & 57.8 & 65.3 \\
\hline \multicolumn{4}{|l|}{ First sex with spouse was wanted or forced } \\
\hline Wanted & 85.8 & 74.4 & 78.0 \\
\hline Forced & 14.2 & 25.6 & 22.0 \\
\hline \multicolumn{4}{|l|}{ Able to refuse one's husband sex } \\
\hline No & 61.5 & 85.4 & 77.8 \\
\hline Yes & 38.5 & 14.6 & 22.2 \\
\hline
\end{tabular}

Many respondents experienced first sex before they had their first period ( 35 percent). When asked about their marital sexual initiation, 22 percent of ever-married women reported that it was a result of force. Girls married at young ages were more likely to report having forced marital sexual initiation. Fifty percent of girls married before age 10 and 38 percent of girls married between ages 10 to 14 reported forced first sex. Among girls married after age 20 , only 3 percent reported forced marital sexual initiation. Likewise, the younger a girl was when she was married, the less likely she is able to refuse her spouse sex. Only 16 percent of girls married before age 10 are able to refuse sex to their spouse compared to 43 percent of girls married after the age of 20 .

Urban women were more likely to discuss domestic duties, maternity services and HIV and AIDS with their husbands than were rural women (Table 9.5). At the same time, less than half of ever-married respondents had discussed any of the topics mentioned, including the number of children to have, MCH services, HIV and AIDS, and fidelity. 
TABLE 9.5: Marriage: Discussion and decision-making within marriage, by topic and type of place of residence

$\begin{array}{ccc}\text { Urban } & \text { Rural } & \text { All } \\ (n=2,012) & (n=4,154) & (n=6,166)\end{array}$

\section{Domestic duties}

Agree with 'You have discussed sharing domestic responsibilities such as cooking or

\section{Childrearing}

Agree with 'Your spouse is the main decision-maker in your children's marriage'

Agree with 'Your spouse is the main decision maker as to whether your children go to school'

\section{Number of children and $\mathrm{MCH}$ services}

Agree with 'You and your spouse have discussed the number of children to have'

\section{HIV and AIDS}

Agree with 'You have talked to your spouse about HIV/AIDS' 


\section{Chapter Ten: Family Planning}

\subsection{FAMILY PLANNING KNOWLEDGE \& ATTITUDES}

Table 10.1 shows the percent of respondents who have heard of family planning (FP) methods, among all women aged 15 to 49, as well as subsamples of women who are currently married and women who are sexually active and have never been married. Nearly all respondents knew of at least one family planning method (94 percent), with most women knowing about injectables ( 92 percent), followed by pills ( 90 percent).

Urban women have higher awareness of family planning methods compared to rural women. Whereas 97 percent of urban women are aware of any family planning method, 92 percent of rural women know of a method. Whereas knowledge of injectables and pills is uniformly high among urban and rural women, rural women have substantially less knowledge about condoms. Among urban women, 79 percent know of the male condom compared to 32 percent of rural women. Never married sexually active women have higher awareness of condoms compared to other categories of women. Among never married sexually active women, 93 percent of urban women and 53 percent of rural women know if the male condom.

Table 10.1 Family planning knowledge: Percentage of all women, currently married women and never married sexually active women knowing family planning methods, by type of place of residence and method

\begin{tabular}{|c|c|c|c|c|c|c|c|c|c|}
\hline & \multicolumn{3}{|c|}{ Urban } & \multicolumn{3}{|c|}{ Rural } & \multicolumn{3}{|c|}{ All women } \\
\hline & $\begin{array}{c}\text { All } \\
(n=3,235)\end{array}$ & $\begin{array}{c}\text { Currently } \\
\text { married } \\
(n=1,568)\end{array}$ & $\begin{array}{c}\text { Never } \\
\text { married, } \\
\text { sexually } \\
\text { active } \\
(n=189)\end{array}$ & $\begin{array}{c}\text { All } \\
(n=5,132)\end{array}$ & $\begin{array}{c}\text { Currently } \\
\text { married } \\
(n=3,562)\end{array}$ & $\begin{array}{c}\text { Never } \\
\text { married, } \\
\text { sexually } \\
\text { active } \\
(n=51)\end{array}$ & $\begin{array}{c}\text { All } \\
(n=8,367)\end{array}$ & $\begin{array}{c}\text { Currently } \\
\text { married } \\
(n=5,130)\end{array}$ & $\begin{array}{c}\text { Never } \\
\text { married, } \\
\text { sexually } \\
\text { active } \\
(n=240)\end{array}$ \\
\hline Any method & 96.9 & 98.9 & 99.0 & 92.4 & 94.3 & 92.7 & 94.2 & 95.7 & 97.8 \\
\hline \multicolumn{10}{|l|}{ Any FP method } \\
\hline Injectable/Depo & 95.0 & 98.1 & 97.7 & 90.0 & 92.0 & 92.4 & 92.0 & 93.8 & 96.7 \\
\hline Pill & 94.6 & 97.3 & 97.4 & 87.6 & 89.6 & 90.0 & 90.4 & 91.9 & 96.0 \\
\hline Male condom & 78.7 & 75.7 & 92.6 & 31.5 & 28.4 & 52.9 & 50.3 & 42.6 & 84.8 \\
\hline Jadelle/implant & 63.6 & 68.6 & 76.6 & 30.4 & 31.4 & 39.7 & 43.6 & 42.5 & 69.4 \\
\hline Safe days & 54.0 & 53.7 & 73.2 & 18.9 & 18.8 & 16.9 & 32.9 & 29.2 & 62.2 \\
\hline IUCD & 55.9 & 59.0 & 76.6 & 13.7 & 13.4 & 20.4 & 30.5 & 27.0 & 65.3 \\
\hline Female condom & 50.5 & 45.5 & 69.2 & 8.5 & 6.6 & 21.4 & 25.2 & 18.2 & 59.8 \\
\hline Vasectomy/TL & 43.5 & 44.9 & 61.1 & 12.5 & 12.8 & 12.9 & 24.8 & 22.4 & 51.6 \\
\hline Withdrawal & 36.2 & 39.2 & 54.9 & 7.8 & 7.5 & 12.2 & 19.1 & 17.0 & 46.6 \\
\hline Emergency contracep. & 27.3 & 25.6 & 46.5 & 6.0 & 5.6 & 8.6 & 14.5 & 11.6 & 39.1 \\
\hline Natural FP & 20.7 & 22.8 & 26.6 & 7.3 & 7.4 & 9.2 & 12.6 & 12.0 & 23.3 \\
\hline Foam/cream/jelly & 12.2 & 12.3 & 16.9 & 2.9 & 2.6 & 7.6 & 6.6 & 5.5 & 15.0 \\
\hline
\end{tabular}




\subsection{EVER USE \& CURRENT USE OF FAMILY PLANNING}

Table 10.2 shows the percentage of currently married women, sexually active never married women and all sexually experienced women ${ }^{15}$ who have every used a family planning method. Fifty percent of currently married women have ever used a family planning method and 39 percent are currently using a method. Fifty-six percent of urban married women and 31 percent of rural married women are currently using an FP method. The most common method used by currently married women is injectables (40 percent), followed by pills (15 percent). Never married, sexually active women report lower rates of injectable use (15 percent), and pill use (18 percent) compared to their married counterparts. However, never married women are more likely to use male condoms (18 percent) than married women (1 percent). Overall, 34 percent of respondents were currently using FP, which suggests a significant increase in FP use since the last DHS in 2005.

Table 10.2 Family planning use: Percentage of all sexually experienced women, ${ }^{1}$ currently married women and never married sexually active women using family planning methods, by type of place of residence and method

\begin{tabular}{|c|c|c|c|c|c|c|c|c|c|}
\hline \multirow[b]{2}{*}{ Characteristic } & \multicolumn{3}{|c|}{ All sexually experienced } & \multicolumn{3}{|c|}{ Urban women } & \multicolumn{3}{|c|}{ Rural women } \\
\hline & $\begin{array}{c}\text { Currently } \\
\text { married } \\
(n=5,043)\end{array}$ & $\begin{array}{c}\text { Never } \\
\text { married, } \\
\text { sexually } \\
\text { active } \\
(n=237)\end{array}$ & $\begin{array}{c}\text { All sexually } \\
\text { active } \\
(n=6,314)\end{array}$ & $\begin{array}{c}\text { Currently } \\
\text { married } \\
(n=1,544)\end{array}$ & $\begin{array}{c}\text { Never } \\
\text { married, } \\
\text { sexually } \\
\text { active } \\
(n=187)\end{array}$ & $\begin{array}{c}\text { All sexually } \\
\text { active } \\
(n=2,200)\end{array}$ & $\begin{array}{l}\text { Currently } \\
\text { married } \\
(n=3,499)\end{array}$ & $\begin{array}{c}\text { Never } \\
\text { married, } \\
\text { sexually } \\
\text { active } \\
(n=50)\end{array}$ & $\begin{array}{c}\text { All sexually } \\
\text { active } \\
(n=4,114)\end{array}$ \\
\hline Ever used FP & 50.1 & 63.0 & 46.8 & 70.9 & 68.8 & 64.4 & 41.3 & 39.2 & 37.6 \\
\hline Currently using FP & 38.5 & 43.5 & 33.7 & 56.1 & 45.7 & 46.0 & 31.0 & 34.2 & 27.2 \\
\hline \multicolumn{10}{|l|}{ Method ever used ${ }^{2}$} \\
\hline Injectable/Depo & 40.3 & 14.5 & 35.3 & 50.0 & 9.5 & 40.3 & 36.1 & 35.3 & 32.7 \\
\hline Pill & 15.3 & 18.3 & 14.8 & 27.5 & 22.7 & 25.6 & 10.0 & 0.3 & 9.2 \\
\hline Male condom & 1.1 & 17.7 & 2.1 & 3.5 & 21.9 & 5.7 & 0.1 & 0.7 & 0.2 \\
\hline Safe days & 1.0 & 5.9 & 1.1 & 3.2 & 7.3 & 3.1 & 0.1 & 0.0 & 0.1 \\
\hline IUCD & 1.6 & 0.5 & 1.5 & 3.4 & 0.6 & 2.7 & 0.9 & 0.0 & 0.8 \\
\hline Vasectomy/TL & 0.3 & 0.0 & 0.2 & 0.6 & 0.0 & 0.4 & 0.1 & 0.0 & 0.1 \\
\hline Jadelle/implant & 1.1 & 0.0 & 1.0 & 1.4 & 0.0 & 1.1 & 1.0 & 0.0 & 0.9 \\
\hline Female condom & 0.2 & 1.1 & 0.3 & 0.5 & 1.4 & 0.5 & 0.1 & 0.0 & 0.1 \\
\hline Withdrawal & 0.2 & 0.8 & 0.2 & 0.5 & 1.0 & 0.6 & 0.1 & 0.0 & 0.1 \\
\hline Emergency contracep & 0.1 & 1.3 & 0.1 & 0.3 & 1.6 & 0.4 & 0.0 & 0.0 & 0.0 \\
\hline Natural FP & 0.1 & 0.0 & 0.1 & 0.2 & 0.0 & 0.2 & 0.0 & 0.0 & 0.0 \\
\hline Number of users & 1,770 & 70 & 1,900 & 830 & 58 & 929 & 940 & (12) & 971 \\
\hline \multicolumn{10}{|l|}{ Use FP to: } \\
\hline Limit pregnancies & 18.6 & 63.9 & 20.4 & 20.1 & 71.0 & 23.3 & 17.3 & (34.7) & 20.4 \\
\hline Space pregnancies & 81.4 & 36.1 & 79.6 & 79.9 & 29.0 & 76.7 & 82.7 & $(65.3)$ & 79.6 \\
\hline \multicolumn{10}{|l|}{$\begin{array}{l}\text { Spouse/partner } \\
\text { knows about FP use }\end{array}$} \\
\hline Yes & 94.7 & 93.3 & 94.2 & 96.7 & 92.0 & 96.1 & 93.4 & $(98.4)$ & 92.7 \\
\hline No & 5.3 & 6.7 & 5.8 & 3.3 & 8.0 & 3.9 & 6.6 & $(1.6)$ & 7.3 \\
\hline
\end{tabular}

${ }_{1}^{1}$ Includes formerly married women, $\quad{ }^{2}$ Percentage may sum to more than percentage ever used, as more than one method is possible $\mathrm{TL}$ = tubal ligation Parenthesis ( ) denote less than 50 cases used in analysis

Most married respondents use FP to space their births ( 80 percent of urban women and 83 percent of rural women). In contrast, among the never married, sexually active women, a greater proportion were using FP to limit their births (64 percent). There was very limited clandestine use of FP. Five percent of married women reported that their partner did not know about their family planning use. Clandestine use of FP was slightly higher in rural areas ( 7 percent) compared to urban areas (4 percent).

${ }^{15}$ All sexually experienced women includes those currently married, never married and formerly married women 
Table 10.3 shows current use of family planning methods among currently married women, by selected background characteristics. FP use is associated with the number of children a woman has, with the highest use among women with one or two children (46 percent). In particular, urban women with one or two children reported high levels of family planning use (61 percent). Current use of family planning is highest among the age group 20 to 29 (44 percent) and 30 to 39 (43 percent), and lowest among women aged 40 to 49 years (19 percent). In urban areas, women aged 20 to 29 reported high rates of FP use (63 percent), whereas in rural areas, the age group with the highest usage were those aged 30 to 39 (38 percent). Substantial variation in current use of family planning was also observed by region. Current use is highest in Addis Ababa (60 percent), followed by SNNPR (53 percent) and Oromiya (41 percent). FP use was lowest in Benishangul Gumuz (22 percent) followed by Tigray (23 percent).

Contraceptive use also varies significantly across educational levels. Thirty percent of women with no education were using family planning methods compared to 63 percent of women with secondary education.

TABLE 10.3 Family planning use: Current use of family planning among currently married women, by selected characteristics

\begin{tabular}{lccc}
\hline Characteristic & Urban $(n=1,567)$ & Rural $(n=3,551)$ & All $(n=5,118)$ \\
\hline All respondents & 56.1 & 31.0 & 38.5 \\
& & & \\
Number of children & & & \\
0 & 41.0 & 23.3 & 29.2 \\
$1-2$ & 61.2 & 34.4 & 45.8 \\
$3-5$ & 60.4 & 32.4 & 39.2 \\
$6+$ & 36.1 & 28.5 & 29.7
\end{tabular}

\section{Age group}

15 to 19

20 to 29

30 to 39

40 to 49
36.5

63.3

55.3

33.7

55.2

41.1

40.3

Amhara

Oromiya

Benishangul- Gumuz

SNNPR

Addis Ababa
62.5

46.8

67.1

60.3
24.0

34.1

37.6

13.8
26.5

43.5

43.0

19.0

\section{Education}

No education

Primary

Secondary

University
40.2

65.1

62.7

83.4
18.0

13.9

30.7

33.0

17.8

46.7

-
23.3

25.2

32.4

40.5

21.7

53.0

60.3

$\begin{array}{ll}27.7 & 29.7\end{array}$

$43.7 \quad 53.0$

$67.1 \quad 63.2$

77.7 


\subsection{SOURCE OF FAMILY PLANNING METHODS}

Table 10.4 shows the source of family planning methods, by type of method. The public sector is the most common source of FP (81 percent), followed by the private sector (13 percent), and other sources (6 percent). Government health centers are the most common source of family planning in the public sector (35 percent), followed by government health posts ( 25 percent). Health extension workers and government hospitals also play a role in providing FP, for 11 percent and 9 percent of users, respectively.

Injectables are mainly obtained from public health centers ( 37 percent), health posts ( 28 percent), and health extension workers (14 percent). Pills are obtained from health centers ( 42 percent), health posts (19 percent) and hospitals ( 7 percent). Condoms are mainly obtained from non-governmental sources, such as shops/ kiosks (57 percent), private clinics (13 percent), or ones partner (11 percent).

TABLE 10.4 Source of family planning: Most recent source of family planning, by method

\begin{tabular}{|c|c|c|c|c|c|c|}
\hline & Pill & IUD & Injectable & Condom & Implant & Total \\
\hline Public sector & 72.0 & $(35.2)$ & 89.1 & 12.5 & 81.0 & 81.0 \\
\hline Public hospital & 7.1 & $(7.0)$ & 10.1 & 3.6 & 11.2 & 9.3 \\
\hline Public health center & 41.8 & $(15.6)$ & 36.8 & 5.0 & 48.4 & 35.3 \\
\hline Health post & 18.8 & $(11.4)$ & 28.1 & 3.4 & 18.6 & 25.0 \\
\hline Health extension worker & 4.3 & $(1.2)$ & 14.1 & 0.5 & 2.8 & 11.4 \\
\hline Private sector & 15.0 & $(60.7)$ & 10.6 & 17.3 & 19.0 & 12.8 \\
\hline Mobile/outreach service & 1.1 & $(0.0)$ & 0.0 & 1.1 & 0.0 & 0.2 \\
\hline Private clinic & 8.5 & $(43.0)$ & 6.7 & 13.1 & 16.0 & 8.3 \\
\hline NGO facility & 2.6 & (17.9) & 2.2 & 2.3 & 0.0 & 2.4 \\
\hline CBRHA & 2.8 & $(0.0)$ & 1.7 & 0.8 & 3.0 & 1.9 \\
\hline Other sources & 12.8 & (3.9) & 0.3 & 70.2 & 0.0 & 6.2 \\
\hline Shop/kiosk & 1.2 & (3.9) & 0.0 & 56.7 & 0.0 & 3.7 \\
\hline Partner & 3.7 & $(0.0)$ & 0.2 & 10.9 & 0.0 & 1.4 \\
\hline Drug store/pharmacy & 7.2 & $(0.0)$ & 0.1 & 2.5 & 0.0 & 1.0 \\
\hline Other & 0.7 & $(0.0)$ & 0.0 & 0.1 & 0.0 & 0.1 \\
\hline Total & 100.0 & 100.0 & 100.0 & 100.0 & 100.0 & 100.0 \\
\hline Number of respondents & 236 & (34) & 1558 & 152 & 50 & 2030 \\
\hline
\end{tabular}

Table 10.5 shows travel time to the source of family planning, waiting time, and amount paid for services. Forty percent of current users spend less than 30 minutes to travel to their FP source of FP, while 29 percent travelled one hour or more. Rural FP travelled considerably more time than urban users. On average, rural women travelled 52 minutes to their source of family planning compared to urban women travelling 31 minutes. Once at the source, most women waited for 15 minutes or less to receive the service (58 percent). However, 16 percent reported waiting for 30 minutes or more. The vast majority (71 percent) received the service for free and 20 percent paid 1 to 5 Birr during their last visit. 
TABLE 10.5 Source of family planning: Travel time, waiting time, and payment for family planning services among current users, by type of place of residence

\begin{tabular}{|c|c|c|c|}
\hline & Urban (n=882) & Rural (n=948) & All $(n=1,830)$ \\
\hline \multicolumn{4}{|l|}{ Time to travel to source of FP (one way) } \\
\hline Less than 30 minutes & 54.8 & 28.7 & 40.3 \\
\hline 30 minutes up to 1 hour & 32.5 & 29.4 & 30.8 \\
\hline 1 hour or more & 12.7 & 41.9 & 28.9 \\
\hline Mean travel time to source (minutes) & 31 minutes & 52 minutes & 42 minutes \\
\hline \multicolumn{4}{|l|}{ Waiting time at source of FP method } \\
\hline 15 minutes or less & 57.9 & 58.6 & 58.3 \\
\hline 16 to 30 minutes & 22.9 & 28.8 & 26.2 \\
\hline More than 30 minutes & 19.2 & 12.6 & 15.5 \\
\hline Mean waiting time for FP service & 24 minutes & 21 minutes & 22 minutes \\
\hline \multicolumn{4}{|c|}{ Amount paid for FP service (in Ethiopian Birr) } \\
\hline None & 63.9 & 76.3 & 70.8 \\
\hline 1 to 5 Birr & 24.1 & 16.6 & 19.9 \\
\hline More than 5 Birr & 12.0 & 7.1 & 9.3 \\
\hline
\end{tabular}

Table 10.6 shows respondents' perceptions of the family planning service provider. The vast majority of clients perceived the provider to be respectful ( 99 percent), nonjudgmental ( 96 percent and friendly (94 percent). Relatively fewer reported that privacy was ensured during the session (82 percent) or that the provider asked if the respondent had questions (73 percent). Only 61 percent felt that the provider would keep the client's information confidential.

TABLE 10.6 Family planning providers: Perception of family planning service providers among current users, by type of place of residence

\begin{tabular}{lccc}
\hline & Urban $(\mathbf{n = 8 8 2})$ & Rural $(\mathbf{n}=\mathbf{9 4 8})$ & All $(\mathbf{n = 1 , 8 3 0})$ \\
\hline Provider treat client with respect & 98.6 & 98.4 & 98.5 \\
Provider was not judgmental & 95.8 & 95.9 & 95.8 \\
Provider was friendly & 93.8 & 94.8 & 94.4 \\
Provider was not rushed/in a hurry & 92.6 & 91.3 & 91.9 \\
Provider ensured privacy during the session & 78.0 & 85.4 & 82.1 \\
Provider asked if client had questions & 70.5 & 74.2 & 72.5 \\
Client asked all the questions she had & 71.5 & 71.1 & 71.5 \\
Thinks provider will keep information confidential & 58.7 & 62.5 & 60.8 \\
\hline
\end{tabular}




\subsection{INTENTION TO USE FAMILY PLANNING}

Table 10.7 shows women's intention to use a method of contraception in the future, which is an indicator of the potential demand for family planning. More than a quarter ( 29 percent) of currently married women who were not using family planning at the time of the survey reported their intention to use a method in the future. Intention to use contraception in the future varies by the number of living children, increasing from 29 percent among women with no child, to 36 percent among those with two children.

TABLE 10.7 Family planning intentions: Percentage of currently married women not using family planning who intend to use a method in the future, by number of children

\begin{tabular}{lcccccc}
\hline $\begin{array}{l}\text { Intention to use FP in } \\
\text { the future }\end{array}$ & \multicolumn{5}{c}{ Number of living children } \\
\cline { 2 - 6 } & $\mathbf{0}$ & $\mathbf{1}$ & $\mathbf{2}$ & $\mathbf{3}$ & $\mathbf{4 +}$ & \multicolumn{2}{c}{ Total } \\
\hline Intends to use & 28.7 & 29.3 & 36.0 & 32.0 & 24.5 \\
Does not intend & 71.3 & 70.7 & 64.0 & 68.0 & 70.5 \\
& & & & \\
Total & 100.0 & 100.0 & 100.0 & 100.0 & 100.0 \\
Number of women & 450 & 597 & 526 & 462 & 1,203 \\
\hline
\end{tabular}

Main reasons given by those not intending to use a method were desire for more children (30 percent), fear of side effects (15 percent), religious reasons (12 percent), partner opposition (11 percent), and lack of knowledge about a source or source too far (8 percent).

TABLE 10.8 Family planning non-use: Percentage of currently married women not intending to use a method, by reason for non-use

\begin{tabular}{lc}
\hline & Non users who do not intend to use \\
\hline Fertility related & 0.4 \\
Infrequent /no sex & 7.3 \\
Menopausal & 0.9 \\
In-fecund & 29.6 \\
Wants to have more children & 2.1 \\
Pregnant/just delivered & \\
& \\
Opposition to use & \\
Partner opposed & 10.5 \\
Religious prohibition & 11.9 \\
& \\
Lack of knowledge & \\
Knows no method & \\
Knows no source & 1.5 \\
& 3.6 \\
Method related reasons & \\
Health concern & \\
Fear of side effects & \\
Lack of access/too far & 3.8 \\
Other & 14.7 \\
Total & 4.4 \\
Number of respondents & 9.3 \\
\hline
\end{tabular}




\subsection{CONDOMS}

Among women age 15 to 49 who were aware of condoms $^{16}$, knowledge about condoms was relatively high (Table 10.9). Eighty-five percent of urban and 80 percent of rural respondents knew that condoms are effective in preventing HIV; 95 percent women knew that they cannot be reused. However, a considerable number of women held negative attitudes towards condoms. More than one third of women felt that moral people do not use condoms; 54 percent of women felt that condoms should not be used within marriage; roughly half felt that condoms are used by promiscuous people.

TABLE 10.9 Condoms: Percentage of women with correct information about condoms and accepting attitudes toward condoms, ${ }^{*}$ by type of place of residence

\begin{tabular}{|c|c|c|c|}
\hline & Urban $(n=2,556)$ & Rural $(n=2,437)$ & All $(n=4,993)$ \\
\hline \multicolumn{4}{|l|}{ Correct information } \\
\hline Disagree with 'Condoms prevent pregnancy but not HIV' & 89.5 & 83.5 & 86.5 \\
\hline Disagree with 'Condoms can be reused' & 97.5 & 91.1 & 94.8 \\
\hline Disagree with 'Condoms are not effective in preventing HIV' & 84.6 & 81.1 & 83.1 \\
\hline \multicolumn{4}{|l|}{ Attitudes towards condoms } \\
\hline Disagree with 'It is a man's responsibility to provide the condom' & 76.3 & 50.0 & 64.7 \\
\hline Disagree with 'Moral people do not use condoms' & 73.9 & 51.5 & 63.2 \\
\hline Disagree with 'Condoms should not be used within marriage' & 55.7 & 35.4 & 45.8 \\
\hline Disagree with 'People who use condoms are promiscuous' & 64.1 & 35.9 & 50.8 \\
\hline
\end{tabular}

Six percent of sexually active urban women used a condom during their last intercourse (1 percent of currently married women, 12 percent of unmarried women) (Table 10.10). Less than 1 percent of rural women used a condom. Partners were the main source of condoms for both urban and rural women (46 percent for urban, 30 percent for rural women). Other sources for urban users include clinics ( 23 percent), chemists/pharmacies (22 percent), kiosks (16 percent), and street vendors (14 percent).

TABLE 10.10 Condoms: Percentage of currently married and sexually active, never married women who used condoms at last sex, by source of condoms and type of place of residence

\begin{tabular}{|c|c|c|c|c|c|c|}
\hline \multirow[b]{2}{*}{ Characteristic } & \multicolumn{3}{|c|}{ Urban } & \multicolumn{3}{|c|}{ Rural } \\
\hline & $\begin{array}{l}\text { Currently } \\
\text { married }\end{array}$ & $\begin{array}{l}\text { Sexually active } \\
\text { unmarried }\end{array}$ & $\begin{array}{l}\text { All sexually } \\
\text { active }\end{array}$ & $\begin{array}{l}\text { Currently } \\
\text { married }\end{array}$ & $\begin{array}{l}\text { Sexually active } \\
\text { unmarried }\end{array}$ & $\begin{array}{l}\text { All sexually } \\
\text { active }\end{array}$ \\
\hline Used a condom at last sex & 1.0 & 12.2 & 5.5 & 0.3 & 0.8 & 0.3 \\
\hline \multicolumn{7}{|l|}{ Source of condoms* } \\
\hline Kiosk & 9.5 & 22.7 & 15.5 & (13.9) & $(13.0)$ & 13.7 \\
\hline Chemists/pharmacies & 24.1 & 20.9 & 22.0 & $(15.4)$ & (6.2) & 12.8 \\
\hline Street vendor & 12.4 & 14.9 & 13.9 & (2.9) & $(11.2)$ & 5.1 \\
\hline Clinic & 22.1 & 23.8 & 22.5 & (8.0) & $(9.8)$ & 8.5 \\
\hline Bar / nightclub & 2.3 & 5.9 & 4.0 & $(0.0)$ & $(0.0)$ & 0.0 \\
\hline Peer educator & 0.0 & 3.5 & 1.7 & (6.4) & $(0.0)$ & 4.7 \\
\hline Partner & 48.3 & 43.3 & 46.4 & $(30.6)$ & $(29.2)$ & 30.2 \\
\hline Number of respondents & 102 & 109 & 211 & 34 & 16 & 50 \\
\hline
\end{tabular}

\footnotetext{
${ }^{16}$ A considerable percentage of women had never heard of condoms or had no exposure to them. These respondents were removed from analysis and only women with knowledge of condoms were included.
} 


\section{Chapter Eleven：Safe Motherhood}

\subsection{PREGNANCY \& CHILDBIRTH}

\section{Attitudes about pregnancy and childbirth}

A series of statements related to attitudes and perceptions of pregnancy and childbirth were read to all women (Table 11.1). Attitudes varied between women in urban and rural areas, especially in relation to the location of childbirth. A significant proportion of rural women felt that most women in their community prefer to deliver at home (87 percent) and the community also expects them to deliver at home (86 percent). A considerable proportion of women felt that women should give birth to sufficient numbers of children to be taken care of in old age ( 80 percent of rural respondents, 70 percent of urban respondents). Sixty-four percent of women felt that death to a woman during childbirth is God's will, with nothing that could have been done to prevent it.

TABLE 11.1 Parenthood: Women's attitudes to childbirth and maternal mortality, by type of place of residence

\begin{tabular}{lccc}
\hline Percentage agreeing with the statement & $\begin{array}{c}\text { Urban } \\
(\mathbf{n = 3 , 2 3 4 )}\end{array}$ & $\begin{array}{c}\text { Rural } \\
(\mathbf{n}=\mathbf{5 , 1 2 7})\end{array}$ & $\begin{array}{c}\text { All } \\
(\mathbf{n}=\mathbf{8 , 3 6 1 )}\end{array}$ \\
\hline Women should have enough children to be taken care of in old age & 70.3 & 79.8 & 76.0 \\
Most women in your community prefer to deliver at home & 33.2 & 87.2 & 65.7 \\
Your community expects women to deliver at home & 31.1 & 86.1 & 64.2 \\
When a woman dies in childbirth, there is nothing that could have been done; it is & 50.9 & 69.4 & 63.6 \\
God's will & & & \\
\hline
\end{tabular}

Desired number of children varied between urban and rural residence, level of education and age cohort. On average, urban women wanted to have 3.8 children, while rural women desired 5.0 children. Respondents who had never been to school reported the ideal number of children as 5.3, compared to 3.8 children among respondents with primary education and 3.4 children desired by women with secondary education. Respondents in the youngest age group (15 to 19) wanted to have an average of 3.4 children, while those aged 30 to 39 wanted 5.4 children and the oldest age group (40 to 49) wanted 6.5 children.

\section{Spousal discussion and support on matters related to childbirth}

Sexually active women were asked about discussions on prenatal care and place of delivery with their spouses/partners, as well as support they receive during pregnancy (Table 11.2). Few couples have discussed medical services in case of emergency (60 percent of urban respondents, 34 percent of rural respondents) or where to deliver (58 percent of urban respondents, 36 percent of rural respondents). Only 58 percent of the respondents said that their spouse helps them with domestic work, and 59 percent reported help with childcare during pregnancy. Urban women reported higher levels of assistance than rural women.

Urban women reported higher levels of access to maternal health services and greater support to use them, compared to rural women. While 51 percent of rural women reported that medical services are too far away, only 29 percent of urban women reported the same. Whereas 83 percent of urban women believed that their family would take them to a clinic in case there was an emergency in childbirth, only 67 percent of rural women believed their families would take them to a clinic. 
TABLE 11.2 Parenthood: Percent distribution of spousal discussion and support on matters related to childbirth (among women with partners), and opinion of all respondents on health facilities, by type of place of residence

\begin{tabular}{lccc}
\hline Percentage agreeing with the statement & Urban & Rural & All \\
\hline You and your spouse have discussed medical care during pregnancy & 59.5 & 33.8 & 42.4 \\
You and your spouse have discussed where you should deliver & 57.6 & 36.3 & 43.3 \\
Your spouse helps you with work when you are pregnant & 61.5 & 56.9 & 58.4 \\
Your spouse helps you care for children when you are pregnant & 63.6 & 57.1 & 59.3 \\
Number of respondents & 1,911 & $\mathbf{3 , 9 3 6}$ & $\mathbf{5 , 8 4 7}$ \\
Medical services for pregnancy are too far away for you to access them & 28.6 & 51.4 & 42.4 \\
If you had an emergency during childbirth, your family would have enough money to & 64.2 & 54.8 & 58.5 \\
take you to the clinic & & 82.8 & 66.6 \\
If you had an emergency during childbirth, your family would take you to the clinic & $\mathbf{3 , 1 4 8}$ & $\mathbf{4 , 9 6 7}$ \\
Number of respondents & $\mathbf{8 , 1 1 5}$ \\
\hline
\end{tabular}

Table 11.3 shows the percentage of women who have ever given birth by place of residence and background characteristics. Sixty-three percent of all women surveyed had given birth. Rural women were more likely to be mothers ( 71 percent), compared to urban women (52 percent). Eighty-seven percent of married women were mothers, as compared with only 4 percent of unmarried respondents. Uneducated women were more likely to have children (84 percent) as compared to 34 percent of women with secondary education.

TABLE 11.3 Parenthood: Percentage of women who have ever given birth, by type of place of residence and selected characteristics

\begin{tabular}{lccc}
\hline & Urban $(n=3,236)$ & Rural $(n=5,131)$ & All $(n=8,367)$ \\
\hline All respondents & 51.6 & 70.8
\end{tabular}

Age group

$\begin{array}{llll}15 \text { to } 19 & 6.6 & 13.5 & 10.5 \\ 20 \text { to } 29 & 54.2 & 79.9 & 69.0 \\ 30 \text { to } 39 & 88.5 & 96.5 & 93.6 \\ 40 \text { to } 49 & 93.8 & 98.2 & 96.9\end{array}$

Region

$\begin{array}{lccc}\text { Tigray } & 68.3 & 71.7 & 71.1 \\ \text { Affar } & 61.8 & 72.2 & 67.6 \\ \text { Amhara } & 53.8 & 70.0 & 65.8 \\ \text { Oromiya } & 53.8 & 72.9 & 66.4 \\ \text { Benishangul- Gumuz } & 61.0 & 76.1 & 73.7 \\ \text { SNNP } & 47.4 & 67.2 & 59.7 \\ \text { Addis Ababa } & 47.0 & - & 47.0\end{array}$

\section{Marital status}

Never married

Education

No education 


\subsection{PRENATAL CARE}

Table 11.4 shows the percentage of women who received prenatal care during their first pregnancy, as well as reasons for not receiving care. Thirty-eight percent of women reported receiving prenatal care. The majority of urban women (66 percent) received care while only 25 percent of rural women did. Only 59 percent of women reported they were accompanied to the health service by their partners. However, 79 percent of women reported that their partners helped to pay for the medical care.

Among those not receiving prenatal care, the most common reason cited was the perception that there was no problem during pregnancy and, therefore, care was not needed (37 percent). The perception that prenatal care is not practiced in the community was cited by 24 percent of the respondents ( 15 percent of urban respondents, 26 percent of rural respondents). Seventeen percent of respondents, each, reported that services were too far or they did not know where to get them. Very few respondents reported cost or partner refusal as barriers to prenatal care.

TABLE 11.4 Parenthood: Percentage of women who received prenatal care and reasons for not receiving prenatal care, by type of place of residence and selected characteristics

\begin{tabular}{lccc}
\hline & Urban & Rural & All \\
\hline Received prenatal care* & 66.4 & 24.5 & 38.3 \\
Male partner accompanied spouse to prenatal care** & 60.2 & 56.7 & 58.7 \\
Male partner helped pay for prenatal care** & 86.6 & 69.8 & 79.4 \\
Number of respondents & $\mathbf{1 , 6 9 5}$ & $\mathbf{3 , 4 4 6}$ & $\mathbf{5 , 1 4 1}$
\end{tabular}

\section{Reason for not receiving prenatal care}

\begin{tabular}{lccc} 
No problem during pregnancy/not needed & 38.2 & 36.1 & 36.5 \\
Not done in the community & 14.9 & 25.6 & 23.7 \\
Services too far & 14.9 & 17.5 & 17.1 \\
Don't know where to get services & 20.5 & 15.9 & 16.7 \\
Services too costly & 0.5 & 0.8 & 0.7 \\
Partner refused & 1.2 & 0.7 & 0.8 \\
Other & 6.5 & 2.6 & 3.3 \\
Don't know & 3.3 & 0.8 & 1.2 \\
mber of respondents & $\mathbf{6 4 9}$ & $\mathbf{2 , 5 7 2}$ & $\mathbf{3 , 2 2 1}$ \\
\hline
\end{tabular}

Women were asked to report the type of service-provider they went to for prenatal care for their first birth (Table 11.5). Thirty-four percent of women received prenatal care from health professionals (doctor, nurse, or health officer), while 3 percent received services from a health extension worker and 1 percent were seen by traditional birth attendant (TBA) or community based reproductive health agent (CBRHA). More than six in ten mothers (62 percent) received no prenatal care for their last birth.

There was a considerable difference in the extent to which urban women received professional care versus rural women ( 65 percent of urban women; 19 percent of rural women). There were also significant regional differences. A very high proportion of women in Addis Ababa (81 percent) received prenatal care services from a health professional, followed by Oromiya (43 percent), and SNNPR (34 percent). The use of antenatal care services appears related to level of education. Women with at least a secondary education are more likely to receive antenatal care from a health professional (87 percent), compared to women who completed a primary education (46 percent), or those with no education (19 percent). 
TABLE 11.5 Prenatal care: Percentage of women who received prenatal care for their first birth, by source of care and selected characteristics

\begin{tabular}{lcccccc}
\hline Characteristic & $\begin{array}{c}\text { Health } \\
\text { professional }\end{array}$ & HEW & TBA/CBRHA & No one & $\begin{array}{c}\text { Total } \\
\text { respondents }\end{array}$ \\
\hline All & 34.1 & 3.1 & 1.1 & 61.7 & 100.0
\end{tabular}

Age at birth

\begin{tabular}{|c|c|c|c|c|c|c|}
\hline$<20$ & 27.0 & 3.0 & 1.2 & 68.8 & 100.0 & 3150 \\
\hline 20 to 34 & 45.3 & 3.3 & 1.1 & 50.3 & 100.0 & 1941 \\
\hline 35 to 49 & (20.3) & 0.0 & 0.0 & (79.7) & 100.0 & (7) \\
\hline
\end{tabular}

Age group

\begin{tabular}{|c|c|c|c|c|c|c|}
\hline 15 to 19 & 34.9 & 7.6 & 2.1 & 55.4 & 100.0 & 192 \\
\hline 20 to 29 & 42.1 & 4.4 & 1.2 & 52.3 & 100.0 & 2422 \\
\hline 30 to 39 & 31.3 & 1.8 & 0.7 & 66.2 & 100.0 & 1638 \\
\hline 40 to 49 & 17.2 & 1.0 & 1.5 & 80.3 & 100.0 & 889 \\
\hline
\end{tabular}

Residence

$\begin{array}{lllllll}\text { Urban } & 65.0 & 0.6 & 0.7 & 33.7 & 100.0 & 1695 \\ \text { Rural } & 18.8 & 4.4 & 1.4 & 75.4 & 100.0 & 3446\end{array}$

Region

$\begin{array}{llllll}\text { Tigray } & 27.1 & 3.2 & 5.1 & 64.6 & 100.0 \\ \text { Affar } & 23.3 & 0.4 & 0.1 & 76.2 & 100.0 \\ \text { Amhara } & 16.1 & 3.5 & 0.7 & 79.7 & 100.0 \\ \text { Oromiya } & 43.3 & 0.9 & 0.0 & 55.8 & 100.0 \\ \text { Benishangul- Gumuz } & 26.9 & 2.1 & 1.3 & 69.7 & 100.0 \\ \text { SNNPR } & 33.7 & 10.6 & 3.0 & 52.7 & 100.0 \\ \text { Addis Ababa } & 81.0 & 0.5 & 0.0 & 18.5 & 100.0\end{array}$

\section{Education}

\begin{tabular}{|c|c|c|c|c|c|c|}
\hline No education & 19.4 & 3.1 & 1.2 & 76.3 & 100.0 & 3509 \\
\hline Grade 1-4 & 45.6 & 5.6 & 2.4 & 46.4 & 100.0 & 591 \\
\hline Grade 5-8 & 63.5 & 3.9 & 0.8 & 31.8 & 100.0 & 549 \\
\hline Grade 9+ & 86.7 & 0.0 & 2.1 & 11.2 & 100.0 & 482 \\
\hline
\end{tabular}




\subsection{DELIVERY CARE}

Table 11.6 shows the location of first birth, by place of residence. Eighty percent of respondents reported that their first birth took place at home with 95 percent of rural women and 50 percent of urban women reporting the first birth at home. Nineteen percent of respondents' first births took place in a clinic or hospital, with 49 percent of urban women and 4 percent of rural women delivering in these facilities.

TABLE 11.6 Delivery: Location of first birth, by type of place of residence

\begin{tabular}{lccc}
\hline & Urban $(\mathbf{n = 1 , 7 9 1 )}$ & Rural $(\mathbf{n = 3 , 7 1 4 )}$ & All $(\mathbf{n = 5 , 5 0 5 )}$ \\
\hline Home & 50.3 & 94.8 & 80.4 \\
Clinic & 16.5 & 2.2 & 6.8 \\
Hospital & 32.7 & 2.1 & 12.0 \\
Forest/field/desert & 0.0 & 0.2 & 0.1 \\
Other & 0.5 & 0.7 & 0.7 \\
\hline
\end{tabular}

Table 11.7 shows location of first birth, by background characteristics. Health facility deliveries were more common among women whose first birth occurred between the ages of 20 to 34 (31 percent). By contrast, the youngest mothers were most likely to deliver in the home ( 88 percent). A significantly higher proportion of children born in urban areas were delivered in a health facility compared to children born in rural areas (49 percent urban; 4 percent rural). There was strong association between education and place of delivery. Only 7 percent of uneducated women delivered in facilities, compared to 78 percnet of women with 9 or more years of education. 
TABLE 11.7 Delivery: Location of first birth, by selected characteristics

\begin{tabular}{lcccccc}
\hline Characteristic & Home & Clinic & Hospital & Others & $\begin{array}{c}\text { Total } \\
\text { respondents* }\end{array}$ \\
\hline All & 80.4 & 6.8 & 12.0 & 0.8 & 100.0
\end{tabular}

Age at birth

$\begin{array}{lcccccc}<20 & 87.5 & 4.7 & 6.9 & 0.9 & 100.0 & 3409 \\ 20 \text { to } 34 & 68.9 & 10.5 & 20.0 & 0.6 & 100.0 & 2041 \\ 35 \text { to } 49 & 82.7 & 0.0 & 17.3 & 0.0 & 100.0 & 7\end{array}$

Age

$\begin{array}{lllllll}15 \text { to } 19 & 78.0 & 7.4 & 14.0 & 0.6 & 100.0 & 204 \\ 20 \text { to } 29 & 78.3 & 8.1 & 12.7 & 0.9 & 100.0 & 2520 \\ 30 \text { to } 39 & 79.4 & 7.0 & 12.7 & 0.9 & 100.0 & 1782 \\ 40 \text { to } 49 & 87.6 & 3.3 & 8.6 & 0.5 & 100.0 & 999\end{array}$

Residence

\begin{tabular}{|c|c|c|c|c|c|c|}
\hline Urban & 50.3 & 16.5 & 32.6 & 0.6 & 100.0 & 1791 \\
\hline Rural & 94.8 & 2.2 & 2.1 & 0.9 & 100.0 & 3714 \\
\hline \multicolumn{7}{|l|}{ Region } \\
\hline Tigray & 93.3 & 2.6 & 3.2 & 0.9 & 100.0 & 850 \\
\hline Affar & 92.1 & 5.0 & 2.5 & 0.4 & 100.0 & 839 \\
\hline Amhara & 92.3 & 1.9 & 5.6 & 0.2 & 100.0 & 816 \\
\hline Oromiya & 77.3 & 6.0 & 15.4 & 1.3 & 100.0 & 819 \\
\hline Benishangul- Gumuz & 87.8 & 2.5 & 3.2 & 6.5 & 100.0 & 886 \\
\hline SNNP & 82.9 & 6.2 & 10.2 & 0.7 & 100.0 & 764 \\
\hline Addis Ababa & 25.7 & 31.7 & 41.6 & 1.0 & 100.0 & 531 \\
\hline \multicolumn{7}{|l|}{ Education } \\
\hline No education & 92.3 & 3.6 & 3.4 & 0.7 & 100.0 & 3809 \\
\hline Grade 1-4 & 77.4 & 8.4 & 12.7 & 1.5 & 100.0 & 621 \\
\hline Grade 5-8 & 60.4 & 12.4 & 26.3 & 0.9 & 100.0 & 567 \\
\hline Grade 9+ & 21.5 & 22.0 & 56.1 & 0.4 & 100.0 & 499 \\
\hline
\end{tabular}

Mothers, mothers-in-law, and other relatives assisted the majority of births (50 percent), particularly in rural areas (64 percent) (Table 11.8). Twenty-three percent of first births were attended by a TBA and 20 percent by a health professional. A significantly higher proportion of births were attended by health professional in urban areas (51 percent) as compared to rural areas (5 percent). A higher proportion of first births were delivered by health professional in Addis Ababa ( 75 percent) followed by Oromiya (23 percent) and SNNPR (18 percent). The percentage of deliveries assisted by a professionals was lowest in Tigray and BenishangulGumuz (6\%) (not shown).

TABLE 11.8 Delivery: Assistance during first birth, by type of place of residence

\begin{tabular}{lccc}
\hline & Urban $(\mathbf{n = 1 , 7 9 1 )}$ & Rural $(\mathbf{n = 3 , 7 1 4})$ & All $(\mathbf{n}=5,505)$ \\
\hline Mother/mother-in-law/other relative & 20.2 & 63.8 & 49.7 \\
Traditional birth attendant & 23.6 & 22.5 & 22.9 \\
Doctor/nurse/health officer & 50.9 & 4.7 & 19.6 \\
Health extension worker / CBRHA & 0.5 & 0.6 & 0.6 \\
No one & 1.4 & 1.6 & 1.5 \\
Other & 3.4 & 6.8 & 5.7 \\
\hline
\end{tabular}




\section{Chapter Twelve: Hiv and Aids Knowledge \& Practice}

\subsection{HIV AND AIDS KNOWLEDGE}

There was extensive awareness of HIV and AIDS among women in the study; 98 percent of urban women and 87 percent of rural women had heard of HIV and AIDS. Older women had slightly lower levels of awareness than younger women, and women with lower levels of education had lower levels of awareness compared to those with higher levels. The regions with the highest levels of awareness of HIV and AIDS were Addis Ababa (99 percent), SNNPR (94 percent), and Tigray (93 percent). Those with the lowest were Beneshangul-Gumuz (82 percent) and Afar (85 percent).

TABLE 12.1 HIV/AIDS: Percent distribution of women who have heard of HIV/AIDS, by type of place of residence and selected characteristics

\begin{tabular}{|c|c|c|c|}
\hline Characteristics & Urban $(n=3,150)$ & Rural $(n=4,354)$ & Total $(n=8,396)$ \\
\hline All Respondents & 98.1 & 87.3 & 91.6 \\
\hline \multicolumn{4}{|l|}{ Age Group } \\
\hline $15-19$ & 98.2 & 89.0 & 93.0 \\
\hline $20-29$ & 98.4 & 87.8 & 92.2 \\
\hline $30-39$ & 98.0 & 87.7 & 91.4 \\
\hline $40-49$ & 97.2 & 82.8 & 87.2 \\
\hline \multicolumn{4}{|l|}{ Marital Status } \\
\hline Never Married & 98.2 & 89.6 & 94.5 \\
\hline Currently Married & 98.7 & 86.9 & 90.4 \\
\hline Divorced/separated/widowed & 95.7 & 87.2 & 90.8 \\
\hline \multicolumn{4}{|l|}{ Region } \\
\hline Tigray & 98.4 & 92.0 & 93.1 \\
\hline Afar & 96.9 & 74.9 & 84.7 \\
\hline Amhara & 96.8 & 87.4 & 89.9 \\
\hline Oromiya & 98.6 & 85.8 & 90.2 \\
\hline Beneshangul Gumuz & 95.6 & 78.9 & 81.6 \\
\hline SNNPR & 98.5 & 90.9 & 93.8 \\
\hline Addis Ababa & 98.8 & - & 98.8 \\
\hline \multicolumn{4}{|l|}{ Educational attainment } \\
\hline No education & 94.5 & 84.0 & 86.1 \\
\hline Primary & 99.0 & 94.1 & 96.4 \\
\hline Secondary & 99.7 & 100.0 & 100.0 \\
\hline University & 100.0 & - & 100.0 \\
\hline
\end{tabular}

Women who were aware of HIV and AIDS were asked to name modes of transmitting the virus (Table 12.2). 
The majority of respondents (93 percent) named sexual intercourse as a mode of transmission. After that, the most commonly mentioned modes were injections with unsterilized needles (57 percent), circumcision with unsterilized tools (32 percent), and transfusion with infected blood ( 25 percent). It is noteworthy only a minority of respondents mentioned mother-to-child transmission as a source of HIV infection. Only 22 percent of women mentioned breast milk, 12 percent mentioned during childbirth, and 7 percent mentioned during pregnancy (7 percent) as a source of HIV infection.

TABLE 12.2 HIV and AIDS: Knowledge of modes of HIV transmission, by method of transmission and type of place of residence

\begin{tabular}{|c|c|c|c|}
\hline Mode of Transmission* & Urban $(n=3,150)$ & Rural $(n=4,354)$ & All $(n=7504)$ \\
\hline Sexual intercourse & 96.0 & 91.1 & 93.1 \\
\hline Injections with unsterilized needles & 59.4 & 55.2 & 57.0 \\
\hline Circumcision with unsterilized tools & 36.9 & 28.4 & 32.0 \\
\hline Transfusion with infected blood & 30.3 & 21.2 & 25.1 \\
\hline Through breast milk & 25.9 & 19.1 & 22.0 \\
\hline Through sex with commercial sex workers & 13.2 & 15.1 & 14.3 \\
\hline During childbirth & 17.1 & 7.4 & 11.5 \\
\hline During pregnancy & 10.8 & 4.5 & 7.2 \\
\hline Don't know & 1.9 & 2.0 & 2.0 \\
\hline
\end{tabular}

Respondents were read a series of statements related to HIV knowledge and misconceptions and asked if the statement is true or false. Most respondents knew that healthy-looking people can be infected with HIV (84 percent). There were considerable differences in levels of knowledge and misconceptions between urban and rural women. For example, while 72 percent of urban women knew that sexually transmitted infections (STIs) can increase one's chances of HIV infection, only 49 percent of rural women were knowledgeable about the increased risk associated with STIs.

TABLE 12.3 HIV and AIDS: Knowledge and misconceptions about HIV and AIDS, by type of place of residence

\begin{tabular}{|c|c|c|c|}
\hline & Urban $(n=3,150)$ & Rural $(n=4,354)$ & All $(n=7,504)$ \\
\hline \multicolumn{4}{|l|}{ Knowledge } \\
\hline $\begin{array}{l}\text { Knows that 'A healthy looking person can be infected } \\
\text { with HIV' }\end{array}$ & 90.0 & 79.4 & 83.9 \\
\hline $\begin{array}{l}\text { Knows that 'Having an STI can increase one's chances of } \\
\text { getting HIV' }\end{array}$ & 71.5 & 49.3 & 58.8 \\
\hline $\begin{array}{l}\text { Knows that 'There is now medical treatment for people } \\
\text { living with HIV, to improve their quality of life' }\end{array}$ & 77.5 & 44.7 & 58.7 \\
\hline \multicolumn{4}{|l|}{ Misconceptions } \\
\hline $\begin{array}{l}\text { Believes that 'Most people get AIDS from accidents with } \\
\text { sharp instruments' }\end{array}$ & 45.4 & 67.6 & 58.2 \\
\hline $\begin{array}{l}\text { Believes that 'One can get AIDs from sharing eating } \\
\text { utensils' }\end{array}$ & 39.9 & 60.3 & 51.6 \\
\hline $\begin{array}{l}\text { Believes that 'People only contract HIV in large towns } \\
\text { and cities' }\end{array}$ & 10.3 & 34.9 & 24.5 \\
\hline Believes that 'One can get HIV from mosquito bites' & 14.8 & 29.7 & 23.4 \\
\hline Believes that 'There is now a cure for AIDS' & 13.5 & 16.3 & 15.1 \\
\hline Comprehensive knowledge about AIDS ${ }^{1}$ & 43.2 & 18.4 & 29.0 \\
\hline
\end{tabular}


a belief widely held in Ethiopia. As well, 52 percent of respondents believed that one can get AIDS from eating utensils (60 percent of rural women and 40 percent of urban women). Misconceptions were much more widely held in rural areas than in urban areas. Sixty-eight percent of rural women felt that accidents were a main mode of HIV transmission compared to 45 percent of urban women. Thirty percent of rural women believed that one could get HIV from mosquito bites. Only 29 percent of respondents (43 percent of urban respondents; 18 percent of rural respondents) had 'comprehensive knowledge' of HIV which reflected a respondent naming sexual intercourse as a mode of transmission, knowing that a healthy looking person can have HIV, and rejecting two common myths regarding transmission from mosquito bites and eating utensils.

\subsection{STIGMA \& DISCRIMINATION}

Respondents were read a series of statements related to stigma and discrimination of those living with HIV and AIDS (Table 12.4). Respondents were most accepting of children with HIV, with 76 percent disagreeing with the statement that an HIV+ child should not attend school with healthy children. Stigma and discrimination appeared to be higher among rural women compared to urban women, for many of the scenarios presented. For example, 78 percent of urban women reported that they would be willing to share food with a person living with HIV, compared to 37 percent of rural women; 76 percent of urban women reported that they would be willing to care for a person with AIDS, compared to 36 percent of rural women. At the same time, more rural women ( 35 percent) compared to urban women (21 percent) felt a teacher living with HIV should be allowed to continue teaching.

TABLE 12.4 HIV and AIDS: Accepting attitudes toward people living with HIV and AIDS, by type of place of residence (percent agreeing or disagreeing with the statements)

\begin{tabular}{|c|c|c|c|}
\hline & $\begin{array}{l}\text { Urban } \\
(n=3,150)\end{array}$ & $\begin{array}{c}\text { Rural } \\
(n=4,354)\end{array}$ & $\begin{array}{c}\text { All } \\
(n=7,504)\end{array}$ \\
\hline Disagree with: 'A child who is HIV+ should not go to school with healthy children' & 87.8 & 67.2 & 76.0 \\
\hline Agree with: 'You would be willing to share food with a person with AIDS' & 77.9 & 37.4 & 54.6 \\
\hline Agree with: 'You would be willing to take care of a person with AIDS' & 75.9 & 35.7 & 52.8 \\
\hline $\begin{array}{l}\text { Agree with: 'If a person is HIV+, he/she should be allowed to keep the information } \\
\text { private and not be forced to share it with his/her community' }\end{array}$ & 33.8 & 40.7 & 37.8 \\
\hline Agree with: 'An HIV+ teacher should be allowed to continue teaching' & 21.0 & 34.9 & 29.0 \\
\hline
\end{tabular}

\subsection{COUNSELING \& TESTING}

Table 12.5 shows the percentage of respondents who have received counseling and testing (CT) for HIV. Overall, 37 percent of women had been tested with considerably more urban women having received the test (55 percent) compared to rural women ( 24 percent). Respondents aged 20 to 29 and 30 to 39 were more likely to have been tested (46 percent of those aged 20 to 29 years; 40 percent of those aged 30 to 39 years), compared to women in the youngest and oldest age groups (27 percent of women aged 15 to 19; 21 percent of women aged 40 to 49). Likewise, those with more education were more likely to have been tested; 64 percent of respondents with at least 9 years of education had been tested compared to 24 percent of women with no education who had been tested. The populations with the highest level of testing were Addis Ababa (57 percent), Oromiya (47 percent) and SNNPR (42 percent). 
TABLE 12.5 HIV and AIDS: Percentage of women aged 15 to 49 who ever been counseled and tested for HIV, by selected characteristics

\begin{tabular}{lccc}
\hline Background Characteristics & Urban $(n=3, \mathbf{1 5 0})$ & Rural $(n=4,354)$ & All $(n=7,504)$ \\
\hline All Respondents & 54.5 & 24.4 & 37.2
\end{tabular}

\section{Age Group}

15-19

20-29

30-39

40-49

\section{Marital Status}

Never Married

Currently Married

Divorced/separated/widowed

$\begin{array}{lll}34.4 & 21.4 & 27.4 \\ 67.1 & 29.0 & 46.1 \\ 62.3 & 25.7 & 39.9 \\ 35.7 & 13.7 & 21.1\end{array}$

\section{Region}

Tigray

Afar

Amhara

Oromiya

Beneshangul Gumuz

SNNP

Addis Ababa

\section{Educational attainment}

No education
Primary
Secondary
University

Table 12.6 shows the main reasons cited for seeking HIV testing, by urban-rural residence. The vast majority of women were tested because they were curious to know their status (69 percent). Other popular reasons given for testing were as part of prenatal care (18 percent), and in preparation for marriage (11 percent).

TABLE 12.6 HIV and AIDS: Main reasons* for having counseling and testing for HIV, by type of place of residence

\begin{tabular}{lccc}
\hline & Urban $(\mathbf{n = 1 , 6 7 8 )}$ & Rural $(\mathbf{n = 1 , 1 5 4 )}$ & All $(\mathbf{n = 2 , 8 3 2 )}$ \\
\hline Wanted to know status/curiosity & 70.0 & 66.2 & 68.6 \\
Part of pregnancy/prenatal care & 22.4 & 11.9 & 18.4 \\
Before marriage & 17.1 & 16.3 & 16.8 \\
Advised by health workers or friends & 6.5 & 18.0 & 10.8 \\
Was sick & 6.6 & 6.1 & 6.4 \\
Other & 2.7 & 5.3 & 3.7 \\
\hline FPercentages may sum to over 100 as more than one reason is possible & &
\end{tabular}


Table 12.7 shows the main reasons cited by sexually experienced women for not being tested. The most commonly cited reasons were having one trusted partner ( 42 percent), and not feeling at risk ( 37 percent). One out of ten respondents reported that they do not feel sick and, therefore, do not need the test, and 6 percent reported that they do not know where to obtain a test.

TABLE 12.7 HIV and AIDS: Main reasons for not receiving counseling and testing for HIV, among sexually experienced women, by type of place of residence

\begin{tabular}{lccc}
\hline & Urban $(\mathbf{n = 1 , 4 6 1 )}$ & Rural $(\mathbf{n = 3 , 1 9 3 )}$ & All $(\mathbf{n = 4 , 4 , 6 5 4 )}$ \\
\hline Have one partner who I trust & 34.3 & 44.4 & 42.1 \\
Not at risk & 40.4 & 35.9 & 37.0 \\
Do not feel sick & 13.3 & 9.5 & 10.4 \\
Do not know where to get the test & 2.9 & 6.3 & 5.6 \\
Never thought of it & 2.7 & 0.8 & 1.2 \\
Not having sex / No current partner & 1.3 & 1.2 & 1.2 \\
No service in vicinity & 0.5 & 0.7 & 0.6 \\
Use condom consistently & 0.5 & 0.0 & 0.1 \\
Other* & 4.1 & 1.2 & 1.8 \\
*Includes against religion, too young, afraid, cannot afford & &
\end{tabular}

Table 12.8 shows the experience of counseling and testing among ever married women in the sample. Fortyone percent of urban couples and 15 percent of rural couples have been counseled and tested for HIV. Among those tested, the majority (63 percent) received testing as a couple. Seven percent of married women fear that their spouse will give them HIV, with 10 percent of urban women and 5 percent of rural women reporting this fear. Thirteen percent of married respondent suspect their spouse has been unfaithful.

TABLE 12.8 HIV and AIDS: Percent distribution of ever married women aged 15 to 49 who have had marital counseling and testing, context of testing, and perception of marital risk

\begin{tabular}{|c|c|c|c|}
\hline & Urban $(n=2,036)$ & Rural $(n=4,153)$ & All $(n=6,189)$ \\
\hline \multicolumn{4}{|l|}{ Marital partners have tested for HIV } \\
\hline Neither have tested & 40.4 & 77.8 & 65.8 \\
\hline Respondents only has tested & 17.0 & 5.4 & 9.1 \\
\hline Spouse of respondent has tested & 1.9 & 2.2 & 2.1 \\
\hline Both husband and wife have tested & 40.7 & 14.6 & 23.0 \\
\hline \multicolumn{4}{|l|}{ Context of testing ${ }^{1}$} \\
\hline Alone & 38.7 & 34.5 & 36.9 \\
\hline As a couple & 61.3 & 65.5 & 63.1 \\
\hline Respondent knows spouse's result ${ }^{1}$ & 80.5 & 80.2 & 80.4 \\
\hline Spouse knows respondent's result ${ }^{1}$ & 86.6 & 83.5 & 85.3 \\
\hline Feels scare that spouse will give respondent HIV & 10.4 & 5.1 & 6.8 \\
\hline Suspects spouse of being unfaithful ${ }^{2}$ & 16.9 & 10.9 & 12.8 \\
\hline
\end{tabular}

${ }^{1}$ Among those receiving testing

${ }^{2}$ Those responding 'yes' and 'don't know' to the question: 'Have you ever suspected your spouse of being unfaithful?' 


\section{Chapter Thirteen: Gender-Based Violence}

\subsection{ATTITUDES TOWARDS GENDER-BASED VIOLENCE}

Respondents were read a series of statements related to domestic and sexual violence and asked if they agree or disagree with the statement (Table 13.1). Statements included whether or not a wife should be able to refuse her husband sex, whether or not it is a man's right to have sex with his wife whenever he wants and whether a man not beating his wife reflects a lack of love for her. A majority of respondents felt a woman should not be able to refuse her husband sex (61 percent) and 58 percent felt that it is a man's right to have sex with his wife whenever he wants. Rural women and older respondents were more likely to old these views, compared to urban women and young respondents.

TABLE 13.1 Gender-based violence: Percent distribution of girls and women holding inequitable or accepting views of gender relations and violence, by type of place of residence and age group

\begin{tabular}{|c|c|c|c|c|c|}
\hline & \multicolumn{2}{|c|}{$\begin{array}{l}\text { Type of place of } \\
\text { residence }\end{array}$} & \multicolumn{2}{|c|}{ Age group } & \multirow{2}{*}{$\begin{array}{c}\text { All } \\
(n=8,397)\end{array}$} \\
\hline & $\begin{array}{l}\text { Urban } \\
(n=3,250)\end{array}$ & $\begin{array}{l}\text { Rural } \\
(n=5,147)\end{array}$ & $\begin{array}{l}15 \text { to } 29 \\
(n=5,417)\end{array}$ & $\begin{array}{l}30 \text { to } 49 \\
(n=2,980)\end{array}$ & \\
\hline $\begin{array}{l}\text { Agrees with 'A woman should not be able to refuse her } \\
\text { husband sex' }\end{array}$ & 51.9 & 66.2 & 58.3 & 64.6 & 60.5 \\
\hline $\begin{array}{l}\text { Agrees with 'It is a man's right to have sex with his wife } \\
\text { whenever he wants to' }\end{array}$ & 41.6 & 68.9 & 54.4 & 64.7 & 58.0 \\
\hline $\begin{array}{l}\text { Agrees with 'If a man does not beat his wife, it means he } \\
\text { does not love her' }\end{array}$ & 4.9 & 20.0 & 12.1 & 17.5 & 13.9 \\
\hline \multicolumn{6}{|l|}{$\begin{array}{l}\text { Believes that wife beating is justified in the following } \\
\text { situations: }\end{array}$} \\
\hline If she argues with her husband & 18.3 & 45.4 & 32.5 & 38.9 & 34.6 \\
\hline If she refuses to have sex with him & 16.7 & 41.4 & 28.6 & 37.6 & 31.6 \\
\hline If she neglects the children & 19.7 & 38.1 & 29.7 & 33.0 & 30.8 \\
\hline If she goes to a neighbor's house without tell him & 14.5 & 35.8 & 26.0 & 30.1 & 27.3 \\
\hline If she burns the food & 13.0 & 35.6 & 24.7 & 30.6 & 26.7 \\
\hline At least one justification mentioned above & 33.0 & 68.5 & 51.8 & 59.6 & 54.4 \\
\hline All five reasons/justifications mentioned above & 4.3 & 11.0 & 7.6 & 9.8 & 8.3 \\
\hline
\end{tabular}

Respondents were read a series of situations and asked of a man beating his wife is justified for the circumstances mentioned. The circumstances in which respondents most commonly found justification in domestic violence were where a woman argues with her husband (35 percent), when she refuses him sex (32 percent), and when she neglects the children (31 percent). Rural women were much more likely to believe that beating is justified, with 45 percent believing men are justified to beat their wives when they argue with their husband and 41 percent felt it is justified when she refuses him sex.

Fifty-four percent of respondents agreed that at least one of the circumstances could justify a beating, with 69 percent of rural women agreeing with at least one reason for beating. Eleven percent of rural women felt beating was justified for all the circumstances mentioned. 


\subsection{DOMESTIC VIOLENCE}

Female respondents who had ever been married were asked questions about control by their husbands, including limiting access to friends and families, and needing to know one's whereabouts at all times (Table 13.2).

TABLE 13.2 Gender based violence: Percent distribution of ever married women experiencing controlling behavior by spouses, by type of place of residence, age group, and marital status

\begin{tabular}{|c|c|c|c|c|c|c|c|}
\hline & \multicolumn{2}{|c|}{$\begin{array}{l}\text { Type of place of } \\
\text { residence }\end{array}$} & \multicolumn{2}{|c|}{ Age group } & \multicolumn{2}{|c|}{ Marital status } & \multirow{2}{*}{$\begin{array}{c}\text { All } \\
(n=8,397)\end{array}$} \\
\hline & $\begin{array}{l}\text { Urban } \\
(n=3,250)\end{array}$ & $\begin{array}{l}\text { Rural } \\
(n=5,147)\end{array}$ & $\begin{array}{l}15 \text { to } 29 \\
(n=5,417)\end{array}$ & $\begin{array}{l}30 \text { to } 49 \\
(n=2,980)\end{array}$ & $\begin{array}{l}\text { Currently } \\
(n=5,188)\end{array}$ & $\begin{array}{l}\text { Formerly } \\
(n=1,030)\end{array}$ & \\
\hline $\begin{array}{l}\text { Partner is jealous or angry when she } \\
\text { talks to a man }\end{array}$ & 21.1 & 25.1 & 24.1 & 23.4 & 23.0 & 27.7 & 23.8 \\
\hline $\begin{array}{l}\text { Partner insists to know where she is } \\
\text { at all times }\end{array}$ & 17.9 & 19.7 & 20.5 & 17.5 & 19.0 & 19.5 & 19.1 \\
\hline $\begin{array}{l}\text { Partner does not permit her to meet } \\
\text { female friends }\end{array}$ & 12.7 & 12.0 & 12.5 & 11.9 & 11.0 & 18.0 & 12.2 \\
\hline $\begin{array}{l}\text { Partner limits contact with her own } \\
\text { family }\end{array}$ & 8.8 & 9.3 & 9.5 & 8.7 & 8.0 & 14.1 & 9.2 \\
\hline $\begin{array}{l}\text { Partner does not trust her with } \\
\text { money }\end{array}$ & 9.7 & 7.7 & 7.9 & 8.9 & 7.4 & 12.6 & 8.3 \\
\hline $\begin{array}{l}\text { Partner frequently accuses her of } \\
\text { being unfaithful }\end{array}$ & 8.0 & 7.6 & 7.9 & 7.6 & 6.7 & 13.1 & 7.8 \\
\hline
\end{tabular}

Nearly one quarter of ever married women reported that their husband is jealous or angry when she talked to other men and 19 percent reported that he insists on knowing where she is at all times. Reporting of controlling behavior did not vary considerably by urban-rural residence or by age group of respondent. However, formerly married women reported higher levels of control by husbands compared to respondents who were married at the time of survey. For example, 28 percent of formerly married women reported husband's jealousy compared to 23 percent of currently married women; 18 percent of formerly married women reported that their former husbands did not permit them to see their female friends compared 11 percent of currently married women.

Table 13.3 shows the experience of domestic violence among ever-married women in the sample. A considerable percentage of women reported the experience of psychological violence, in particular insults, reported among 7 percent of ever-married women. Overall 10 percent of women had experienced physical violence from their husbands. Formerly married women were more likely to have experienced physical violence (14 percent) compared to currently married women (9 percent). The most common types of violence experience were being slapped ( 7 percent) and being pushed ( 5 percent). Three percent of ever-married women report having ever hit or beaten their spouses ( 4 percent of urban women and 3 percent of rural women). 
TABLE 13.3 Gender-based violence: Percent distribution of ever married women experiencing domestic violence, by type of place of residence, age group, and marital status

\begin{tabular}{|c|c|c|c|c|c|c|c|}
\hline & \multicolumn{2}{|c|}{$\begin{array}{l}\text { Type of place of } \\
\text { residence }\end{array}$} & \multicolumn{2}{|c|}{ Age group } & \multicolumn{2}{|c|}{ Marital status } & \multirow{2}{*}{$\begin{array}{c}\text { All } \\
(n=4,785)\end{array}$} \\
\hline & $\begin{array}{l}\text { Urban } \\
(n=1,606)\end{array}$ & $\begin{array}{l}\text { Rural } \\
(n=3,179)\end{array}$ & $\begin{array}{l}15 \text { to } 29 \\
(n=2,633)\end{array}$ & $\begin{array}{l}30 \text { to } 49 \\
(n=2,152)\end{array}$ & $\begin{array}{l}\text { Currently } \\
(n=3,972)\end{array}$ & $\begin{array}{l}\text { Formerly } \\
(n=783)\end{array}$ & \\
\hline \multicolumn{8}{|l|}{ Psychological violence } \\
\hline $\begin{array}{l}\text { Spouse ever humiliated in front of } \\
\text { others }\end{array}$ & 5.1 & 4.7 & 4.3 & 5.4 & 4.1 & 8.3 & 4.8 \\
\hline $\begin{array}{l}\text { Spouse ever threatened to hurt you } \\
\text { or someone close to you }\end{array}$ & 3.0 & 2.7 & 2.0 & 3.8 & 2.0 & 6.5 & 2.8 \\
\hline $\begin{array}{l}\text { Spouse ever insulted you or made } \\
\text { you feel bad about yourself }\end{array}$ & 7.3 & 7.4 & 6.7 & 8.2 & 6.6 & 11.2 & 7.4 \\
\hline \multicolumn{8}{|l|}{ Physical violence } \\
\hline $\begin{array}{l}\text { Spouse ever pushed, shook or threw } \\
\text { something at you }\end{array}$ & 6.0 & 4.8 & 4.7 & 5.8 & 4.4 & 9.0 & 5.2 \\
\hline Spouse ever slapped you & 7.7 & 6.2 & 7.2 & 6.0 & 6.0 & 10.1 & 6.7 \\
\hline Spouse ever punched you & 4.1 & 3.1 & 3.3 & 3.6 & 2.8 & 6.9 & 3.5 \\
\hline Spouse ever kicked or dragged you & 3.4 & 2.9 & 3.3 & 2.8 & 2.5 & 5.5 & 3.1 \\
\hline Spouse ever forced sex & 2.0 & 1.7 & 1.9 & 1.7 & 1.3 & 4.3 & 1.8 \\
\hline $\begin{array}{l}\text { Ever experienced any physical } \\
\text { violence from spouse }\end{array}$ & 10.3 & 9.5 & 10.1 & 9.4 & 8.9 & 13.9 & 9.8 \\
\hline Beaten in the last three months & 1.9 & 2.3 & 2.2 & 2.0 & 3.2 & 2.5 & 2.2 \\
\hline
\end{tabular}

Among female victims of domestic violence, 11 percent believe they deserved it, with more rural women (14 percent) holding this belief than urban women (7 percent). Nearly 40 percent of women told someone about the violence. Most women who told someone told a neighbor (47 percent), followed by a relative other than parent or sibling ( 24 percent), a mother (19 percent) or father (18 percent). Sixteen percent of those telling someone about the instance told a policeman or other official. One quarter of women who had been beaten, reported that their spouse had been drinking or doing drugs during the last violent event. Three percent of women report that they have hit or beaten their spouse at one time.

TABLE 13.4 Gender-based violence: Percent distribution of victims of violence (in last three months) who think they deserved being beaten by husband or told someone about it, by type of place of residence

\begin{tabular}{lccc}
\hline & Urban $(\mathbf{n}=\mathbf{5 9})$ & Rural $(\mathbf{n = 1 1 1})$ & All $(\mathbf{n = 1 7 0})$ \\
\hline Thinks she deserved violence & 6.7 & 13.9 & 11.3 \\
Told someone about the beating/violence & 33.7 & 42.9 & 39.4 \\
Someone tried to intervene during last instance & 65.5 & 47.5 & 53.5 \\
Spouse had been drinking / doing drugs during last violent act & 24.8 & 26.5 & 25.9 \\
\hline
\end{tabular}




\subsection{RAPE \& COERCION}

Seventy-three percent of respondents were sexually experienced, amongst whom 96 percent had been married. Respondents were asked about the context of their first sexual experience (Table 13.5). Overall, one quarter of sexually experienced women experienced sexual initiation under coercive conditions (19 percent of urban respondents, 29 percent of rural respondents). Seventeen percent of women reported their first sex was rape/forced (12 percent of urban women, 19 percent rural women), while 17 percent reported insistence, 11 percent report partner threats, and 6 percent said they were beaten.

The most common perpetrators of coercion or force were intimate partners. Among those reportedly using force, 92 percent were husbands, 6 percent were boyfriends or fiancés, and 2 percent were acquaintances or classmates.

TABLE 13.5 Rape and coercion: Percentage of sexually experience women aged 15 to 49 who experienced forced or coerced first sex, by type of place of residence

\begin{tabular}{lccc}
\hline & Urban $\mathbf{( n = 2 , 2 3 5 )}$ & Rural $(\mathbf{n = 4 , 1 8 6 )}$ & All $(\mathbf{n = 6 , 4 2 1 )}$ \\
\hline Partner insisted/would not take "no" for an answer & 13.2 & 19.1 & 17.1 \\
Physical force/rape & 12.0 & 19.4 & 16.8 \\
Partner threatened & 8.9 & 12.1 & 11.0 \\
Given money or gifts & 12.2 & 6.9 & 8.7 \\
Partner hit or beat & 5.4 & 6.3 & 6.0 \\
At least one coercive condition & 19.2 & 28.9 & 25.0 \\
\hline F
\end{tabular}

Many victims blamed themselves for being raped (15 percent) and few told anyone about the experience ( 9 percent). Only 3 percent sought medical assistance and 2 percent sought legal assistance. Seeking assistance was particularly low among rural victims with between 1 and 2 percent seeking legal, psychological or medical support following the event.

TABLE 13.6 Rape: Percent distribution of victims of rape who told someone about it and sought assistance, by type of place of residence

\begin{tabular}{lccc}
\hline & Urban $(\mathbf{n = 1 1 6})$ & Rural $(\mathbf{n = 2 7 1 )}$ & All $(\mathbf{n = 3 8 7 )}$ \\
\hline Told someone about being forced to have sex & 13.4 & 7.8 & 9.2 \\
Sought medical assistance & 5.7 & 1.9 & 2.8 \\
Sought legal assistance & 7.4 & 0.2 & 1.9 \\
Sought psychological support or counseling & 1.9 & 1.1 & 1.3 \\
Blamed herself for what happened & 32.1 & 9.1 & 14.5 \\
\hline
\end{tabular}




\subsection{INFORMATION ON GENDER-BASED VIOLENCE}

Respondents were asked if they had received information or heard messages related to GBV in the year prior to survey (Table 13.6). Respondents varied considerably between urban and rural residents. Among urbanites, 37 percent had heard a GBV message in the last year compared to 8 percent of rural residents. The most common source of information was radio (81 percent of urban respondents; 35 percent of rural respondents), followed by television (64 percent of urban respondents; 2 percent of rural respondents), and friends (12 percent of urban respondents; 40 percent of rural respondents). Among rural residents, community meetings ( 24 percent), teachers (18 percent) and kebele officials (15 percent) were also important sources of information.

TABLE 13.7 Gender-based violence: Percentage of women 15 to 49 receiving information on GBV in the last year, by source of information and type of place of residence

\begin{tabular}{|c|c|c|c|}
\hline & Urban $(n=3,222)$ & Rural $(n=5,117)$ & All $(n=8,339)$ \\
\hline Received information/heard message on GBV in last year & 36.6 & 8.3 & 19.6 \\
\hline \multicolumn{4}{|l|}{ Source of information/message on $\mathrm{GBV}^{1}$} \\
\hline Radio & 81.1 & 35.4 & 69.4 \\
\hline Television & 63.7 & 2.3 & 48.1 \\
\hline Friends & 11.7 & 39.5 & 18.8 \\
\hline Newspaper & 15.7 & 3.3 & 12.5 \\
\hline Teachers & 8.9 & 17.7 & 11.2 \\
\hline Community meeting & 3.8 & 24.2 & 9.0 \\
\hline Police / law enforcement & 5.1 & 4.6 & 5.0 \\
\hline Parents & 2.4 & 11.3 & 4.7 \\
\hline Kebele officials & 1.3 & 14.5 & 4.7 \\
\hline Health worker & 1.6 & 9.8 & 3.7 \\
\hline Billboard/pamphlet & 2.7 & 0.4 & 2.1 \\
\hline Priest / imam & 0.3 & 1.0 & 0.5 \\
\hline
\end{tabular}




\section{Chapter Fourteen: Information \& Services}

\subsection{SOURCES OF INFORMATION}

Respondents were asked where they had ever received information on reproductive health issues such as pregnancy and family planning (Table 14.1). Husbands and female friends were important sources of information on issues such as pregnancy and family planning, with roughly half of all respondents receiving information from their husbands and approximately 4 out of 10 receiving information from friends. Among community resources, teachers and health extension workers were frequently cited as sources of information. One quarter of respondents had receiving information on pregnancy and family planning from teachers. Twenty percent had received information from health extension workers, who were particularly important sources of information in rural areas.

TABLE 14.1 Information: Percentage of women 15 to 49 receiving information on pregnancy and family planning, by source of information and type of place of residence

\begin{tabular}{|c|c|c|c|c|c|c|}
\hline & \multicolumn{3}{|c|}{ Pregnancy } & \multicolumn{3}{|c|}{ Family planning } \\
\hline & $\begin{array}{c}\text { Urban } \\
(n=2,882)\end{array}$ & $\begin{array}{c}\text { Rural } \\
(n=4,544)\end{array}$ & $\begin{array}{c}\text { All } \\
(n=7,426)\end{array}$ & $\begin{array}{l}\text { Urban } \\
(n=2,882)\end{array}$ & $\begin{array}{c}\text { Rural } \\
(n=4,544)\end{array}$ & $\begin{array}{c}\text { All } \\
(n=7,426)\end{array}$ \\
\hline \multicolumn{7}{|l|}{ Family \& friends } \\
\hline Husband & 63.9 & 52.1 & 55.8 & 60.2 & 41.3 & 47.3 \\
\hline Friend & 50.8 & 35.2 & 41.2 & 49.0 & 31.0 & 37.9 \\
\hline Boyfriend & 33.2 & 16.7 & 23.6 & 32.9 & 16.8 & 23.5 \\
\hline Mother & 29.3 & 28.1 & 28.6 & 23.0 & 19.3 & 20.7 \\
\hline Sibling & 30.7 & 18.7 & 23.2 & 28.9 & 15.6 & 20.6 \\
\hline Father & 10.8 & 10.1 & 10.4 & 10.1 & 8.9 & 9.3 \\
\hline \multicolumn{7}{|l|}{ Community resources } \\
\hline Teacher & 30.4 & 17.5 & 24.2 & 32.4 & 20.7 & 26.8 \\
\hline Health extension worker & 10.9 & 25.0 & 19.8 & 11.3 & 27.8 & 21.7 \\
\hline Service provider & 18.4 & 14.4 & 16.1 & 20.1 & 16.1 & 17.8 \\
\hline Community conversation & 12.0 & 11.2 & 11.5 & 14.0 & 13.1 & 13.5 \\
\hline Community leader & 7.0 & 6.5 & 6.7 & 8.2 & 9.0 & 8.7 \\
\hline Religious leader & 6.0 & 4.0 & 4.8 & 6.5 & 4.8 & 5.4 \\
\hline \multicolumn{7}{|l|}{ Media } \\
\hline Radio & 57.2 & 22.8 & 39.1 & 62.5 & 25.2 & 42.8 \\
\hline Newspaper & 21.4 & 5.8 & 14.2 & 21.4 & 5.0 & 13.9 \\
\hline
\end{tabular}




\subsection{PREFERENCES FOR SERVICES}

Respondents were asked to suppose they needed reproductive health services and to think about the characteristics of the service that was important to them. They were read a series of service qualities and asked if the characteristic was important in their choice of services (Table 14.2). Most of the characteristics mentioned were considered extremely important to respondents, especially the friendliness of the provider (67 percent), the proximity of the service ( 65 percent), and the cost of service ( 65 percent). Less than half of the respondents ( 47 percent) felt it was extremely important that the provider is female.

TABLE 14.2 Services: Percentage of women 15 to 49 citing service characteristics as 'very important' in choice of service, by characteristic and type of place of residence

\begin{tabular}{lccc}
\hline & Urban $(\mathbf{n = 3 , 2 3 2})$ & Rural $(\mathbf{n = 5 , 1 3 5 )}$ & All $(\mathbf{n = 8 , 3 6 7 )}$ \\
\hline Staff are friendly & 69.4 & 65.9 & 67.3 \\
Service is close to home & 70.6 & 60.7 & 64.6 \\
Services are low cost or free & 68.5 & 62.1 & 64.6 \\
Short waiting time & 67.4 & 60.7 & 63.4 \\
The provider keeps information confidential & 67.6 & 58.0 & 61.9 \\
The provider is not rushed and takes their time & 66.7 & 58.0 & 61.4 \\
The service hours are convenient & 65.0 & 56.7 & 60.0 \\
The provider is a female & 46.3 & 46.8 & 46.6 \\
\hline
\end{tabular}

\subsection{SERVICE UTILIZATION}

Respondents were read series of community services or health facilities and asked if they had utilized the services in the previous year (Table 14.3). Among health facilities mentioned, urban women were more likely to have visited facilities compared to rural women, with the exception of health posts. Over 40 percent of urban women and 16 percent of rural women had visited a hospital in the past year; 32 percent or urban women had been to a private clinic compared to 12 percent of rural women. Compared to urban respondents, rural women were more likely to utilize service available in their communities, such as health extension workers (26 percent of rural respondents, 10 percent of urban respondents) or community conversations (23 percent of rural respondents, 19 percent of urban respondents). Among the services mentioned, religious services were the ones most utilized, with 87 percent of women having attended a Church or Mosque in the previous year.

TABLE 14.3 Services: Percentage of women 15 to 49 frequenting services in the last year, by type of service and type of place of residence

\begin{tabular}{|c|c|c|c|}
\hline & Urban $(n=3,204)$ & Rural $(n=5,092)$ & All $(n=8,296)$ \\
\hline \multicolumn{4}{|l|}{ Community resources } \\
\hline Attended a Church or Mosque & 91.2 & 84.1 & 86.8 \\
\hline Attended community conversation & 18.5 & 23.4 & 21.5 \\
\hline Seen health extension worker & 9.8 & 25.6 & 19.5 \\
\hline Been you women's group or youth group & 8.5 & 5.1 & 6.4 \\
\hline \multicolumn{4}{|l|}{ Health facilities } \\
\hline Been to hospital & 43.5 & 15.8 & 26.5 \\
\hline Been to health post & 14.4 & 26.2 & 21.6 \\
\hline Been to private clinic & 31.5 & 11.9 & 19.5 \\
\hline Been to health center & 25.5 & 15.7 & 19.5 \\
\hline
\end{tabular}


Travel time to facilities may account for differences in utilization. Among women attending services, rural women reported significantly more travel time than urban women ${ }^{17}$, especially for health services (Table 14.4). For example, the average travel time to a health center for a rural woman was over 1 hour (75 minutes), compared to $1 / 2$ an hour for urban women. Rural respondents travelled an average of nearly 2 hours (115 minutes) to a hospital, compared to less than 1 hour (50 minutes) reported by urban respondents. In contrast, travel to religious services took an average of less than $1 / 2$ an hour among both urban and rural residents.

TABLE 14.4 Services: Mean travel time (in minutes, one way) to services, by type of service and type of place of residence

\begin{tabular}{llc}
\hline & Urban & Rural \\
\hline Community resources & & \\
Church or Mosque & 19 & 26 \\
Community conversation & 21 & 35 \\
Health extension worker & 24 & 32 \\
Women's group or youth group & 25 & 38 \\
& & \\
Health facilities & & 115 \\
Hospital & 50 & 51 \\
Health post & 27 & 66 \\
Private clinic & 31 & 75 \\
Health center & 29 & \\
\hline
\end{tabular}

Three percent of respondents reported that they had not gone for a health service at one time when they needed it. The reasons for needing a health service were mainly general health problems such as stomach problems, wounds and malaria. Among those not going for health services when needed, 23 percent reported needing family planning. In these instances, the main barriers to seeking services were lack of facilities in the area (30 percent), no money for services (26 percent), no time to seek services (23 percent), not knowing where to go (8 percent) and family disapproval or opposition (8 percent). 


\section{Chapter Fifteen: Recommendations For Programs}

"Ethiopia Gender Survey: A Study in Seven Regions" highlights significant differences between women residing in urban and rural areas of Ethiopia and suggests programmatic directions to better serve Ethiopian girls and women. Based on the study findings, recommendations from the study team are:

Address inequitable gender attitudes: A considerable proportion of women hold inequitable gender attitudes, including attitudes supporting gender-based violence. Such attitudes undermine women's abilities to fully participate in civic life and to reach their full potential. Socializing institutions such as families, communities, schools, and religious institutions should work to address attitudes that limit girls' and women's role, and norms that encourage discrimination and violence.

Expand schooling opportunities, especially in rural areas, and address practices that limit girls' participation: With significant urban-rural differences in school attendance and educational attainment, additional efforts should be devoted to expanding schooling in rural areas, particularly at the secondary level. Family disapproval was a main barrier to schooling, and early marriage was a common reason among girls leaving school early. Negative attitudes towards girls' education could be addressed through socializing institutions such as communities and religious institutions, as well as the practice of early marriage in some communities.

Expand livelihoods opportunities and move beyond skills training: Work roles available to girls and women are limited, with most females involved in petty trade, farming and domestic work. The most common paid work among urban females was domestic work, which is considered one of the lowest status forms of work. Few respondents had received vocational training. Among those who had, few had put their skills to use, mainly because of their inability to find a job. Livelihoods initiatives should go beyond skills training to include internships or job placement, effectively easing the transition to the work world after training. Among the women who had received entrepreneurship training and micro-credit, most reported that it improved their economic status. Expansion of entrepreneurship training and micro-credit may benefit certain groups of women who are appropriate and equipped for such opportunities.

Intensify programs combating female genital mutilation/cutting in areas of high prevalence: The practice of FGM/C is generally declining in Ethiopia, though there are regions where the most extreme forms are still practiced among a majority of girls. The highest rates of circumcision were reported in Afar, SNNPR and Oromiya (Somali Region was not included in this survey). Significant proportions of respondents in these regions still support the practice, frequently citing tradition and religion. Programs should address these beliefs, especially among rural populations, and expand understanding of the negative health effects of the practice.

Expand programs to delay marriage and promote increased communication and cooperation within marriage: Early marriage is still common in some regions of Ethiopia. The practice effectively limits a girl's education and personal development, and is associated with early sexual initiation and childbirth. Efforts should be expanded to simultaneously delay marriage and extend schooling for girls, particularly in rural areas. Among those already married, programs should encourage open communication between partners and focus additional attention on reducing domestic violence.

Expand mix of family planning methods available and promote safe motherhood initiatives: Significant gains have been made in the expansion of family planning (FP), with this survey estimating that 39 percent of married women are using a method. However, the vast majority of FP users are using injectables or pills. 
Programs should expand quality services providing other FP methods, to better respond to the preferences and lifestyles of women in Ethiopia. Whereas significant increases in FP use are reflected in the survey, a significant proportion of Ethiopian women still deliver in the home. Additional efforts should be directed to safe motherhood initiatives, particularly for women in rural areas.

Increase attention to gender based violence: There was high acceptance of gender based violence among respondents and considerable reporting of domestic violence and sexual violence. A large proportion of girls and women experienced forced sexual initiation, frequently perpetrated by intimate partners. Expansion of GBV prevention, support and treatment programs are urgently needed, especially in rural areas. In addition, programs targeting men and boys should address male gender roles and attitudes that perpetuate violent behavior among men.

Expand resources and services in rural areas, as well as programs delivered through religious institutions: The study suggested that many rural areas lack the necessary infrastructure to support communities, including schools, health facilities and other social services. Development efforts should focus on remote rural areas where infrastructure and services are extremely limited. At the same time, religious institutions enjoy significant coverage and reach in these areas, and represent venues through which a significant proportion of the population can be reached, including remote populations. Religious institutions should be strengthened to address additional health and social issues among their congregations, including HIV prevention, education, early marriage, and domestic violence, among others. 


\section{Appendix A: SAmple Information}

TABLE A1: Study districts/woredas and sample per site, by region and type of respondent

\begin{tabular}{|c|c|c|c|c|}
\hline Region \& District/Woreda & $\begin{array}{c}\text { No of enumeration } \\
\text { areas (EAs) }\end{array}$ & Exp or Comp. & $\begin{array}{l}\text { Girls } 12-24 \text { (age 12-14 } \\
\text { removed in this report) }\end{array}$ & Women 25-49 \\
\hline \multicolumn{5}{|l|}{ Tigray } \\
\hline Naeder Adet & 8 & Exp & 160 & 160 \\
\hline Samre Saharti & 8 & Exp & 160 & 160 \\
\hline Gulo Mehada & 8 & Exp & 160 & 160 \\
\hline Kola Temben & 12 & Comp & 240 & 240 \\
\hline \multicolumn{5}{|l|}{ Afar } \\
\hline Dubti & 8 & Exp & 160 & 160 \\
\hline Awash Fentale & 8 & Exp & 160 & 160 \\
\hline Argoba Liyu/Gach & 8 & $\operatorname{Exp}$ & 160 & 160 \\
\hline TBD & 6 & Comp & 120 & 120 \\
\hline Mile & 6 & Comp & 120 & 120 \\
\hline \multicolumn{5}{|l|}{ Amhara } \\
\hline Gonder & 6 & Exp & 120 & 120 \\
\hline Enarj Enawga & 6 & Exp & 120 & 120 \\
\hline Sekela & 6 & Exp & 120 & 120 \\
\hline Sekota & 6 & Exp & 120 & 120 \\
\hline Machakel & 6 & Comp & 120 & 120 \\
\hline Ambasel & 6 & Comp & 120 & 120 \\
\hline \multicolumn{5}{|l|}{ Oromiya } \\
\hline Sekoru & 6 & Exp & 120 & 120 \\
\hline Sululta & 6 & Exp & 120 & 120 \\
\hline Adama & 6 & Exp & 120 & 120 \\
\hline Nekemtie & 6 & Exp & 120 & 120 \\
\hline Tiro Afeta & 6 & Comp & 120 & 120 \\
\hline Lome & 6 & Comp & 120 & 120 \\
\hline \multicolumn{5}{|l|}{ Beneshangul Gumuz } \\
\hline Pawi & 12 & Exp & 240 & 240 \\
\hline Homosha & 12 & Exp & 240 & 240 \\
\hline Sherkole & 12 & Exp & 240 & 240 \\
\hline Dibate & 12 & Comp & 240 & 240 \\
\hline \multicolumn{5}{|l|}{ SNNP } \\
\hline Sodo Zuria & 12 & Exp & 240 & 240 \\
\hline Hawasa Zuria & 12 & Exp & 240 & 240 \\
\hline Dale & 12 & Comp & 240 & 240 \\
\hline \multicolumn{5}{|l|}{ Addis Ababa } \\
\hline Kolfe Keraniyo & 12 & Exp & 240 & 240 \\
\hline Addis Ketema & 12 & Exp & 240 & 240 \\
\hline \multirow[t]{2}{*}{ Gulele } & 12 & Comp & 240 & 240 \\
\hline & & & 720 & 720 \\
\hline Total sample & & & 5040 & 5040 \\
\hline
\end{tabular}




\section{Appendix B: Data Collection StafF}

Survey coordinator: Lemi Negeri

\section{Coordinators}

Alemayehu Tesfay

Asfaw Getahun

Assefa Negera

Bayisa Jebessa

Berhane W/Gebrael

Berhanu Arba

Desalegn Doja

Esubalew Derseh

Abebe Sahilu
Abelelom Kahasay
Abreham Wubshet
Amanuel Angolo
Aster Eyob
Awel Jemal
Ayelech Habte
Ayub Temam
Birhanu Demeke
Eneyew Temesgen
Esayas Fekadeselase

$\begin{array}{ll}\text { Esubalew Derseh } & \text { Mulugeta Asefa } \\ \text { Gashaye Semahegn } & \text { Sheko Guru } \\ \text { Hafiz Shahawol } & \text { Solomon G/Mariam } \\ \text { Kahsay Arefe } & \text { Sori Dadi } \\ \text { Legesse Hadish } & \text { Taye Alemayehu } \\ \text { Markos Shimels } & \text { Tefera Atalay } \\ \text { Mulualem Tegegn } & \text { Tesfaye Azimera } \\ & \text { Zerihun Befekadu }\end{array}$

\section{Supervisors}

Eyeberu Demsash

Faitu Adere

Getahun Teferi

Kalayu Halefom

Kassahun Tilahun

Kenaw Babu

Kibrom Abadi

Merga Abetu

Mihretu Gezahegn

Shimels Getahun

Takele Negewo
Temesgen Eneyew

Temesgen Nigatu

Teshale Hirphasa

Teshome Tadesse

Tewodros Lulu

Tsegaye Alemu

Tsegaye Kejela

Tsegeberhan G/Hiwot

Tsige Yohannes

Yasabu Shiferaw

Zer'u Berhane 


\section{Interviewers}

Abdulkadir Kassa

Abdulkerim Benur

Abeba Belay

Abebe Ayalew

Abebech Tsegaye

Abel G/Egziabher

Aberash Girmay

Aberash Halefom

Aberham Afeta

Abiot Saketa

Abrehet Tekle Geworgis

Adane Shibesh

Adanech Chemeda

Addis Tsegaye

Addise Zegeye

Adugna Kenaw

Africawit Awel

Agegnehu G/Selase

Agegnehush Asires

Alemayehu Abebe

Alemayehu Deme

Alemtsehay Tadesse

Alemtsehay Wana

Almaz Girma

Amelework Mamo

Ansha Yimer

Aregash Assefa

Aregash Yigezu

Asaye Tadele

Asegidew Abebe

Askalu Tekle

Asmaru Tsegaw

Asnake Teka

Asnakech Asefa

Asresash Alemu

Aster Sehul

Ayalew Alemu

Ayalew Belay

Ayalkibet Guta

Ayinalem Berhanu

Azalesh tekle

Badege Ayele

Basmit Solomon

Bayiray Arefe

Bayush Adane

Bayush Sisay

Behailu Belache

Bejigie Ibaba

Belay Nigatu

Beletu Duguma
Etsifi Afework

Eyerus Ano

Fasika Esubalew

Fekadu Geta

Fekadu mitku

Fekadu Shinkute

Feleke Chamo

Felekech kifle

Fiker Ayele

Fikrte Chane

Gebrekiros Woldegerima

Gebresilase g/Tsadik

Gemechu Meta

Genet kebede

Getachew Berhe

Girma Tesema

Gitu Khassay

Guday Tamre

Habtam Yirgete

Habtam Zemene

Haile Michael Girma

Hailu Banjaw

Haimanot Libenu

Hana Kemal

Haregewoin Addis

Haregewoin Tekle

Helen Adhanom

Helen Arage

Helen Eliyas

Henock Ayele

Hiwot G/Medihn

Hurube Fekadu

Jember Worku

Kalyu Atsebeha

Kassa Alemu

Kebede Gudisa

Kebrikulu Mengistu

Kelemu Bayle

Lemlem Khassay

Lensa Bikela

Lensa Dereje

Letegebrael G/Medihn

Leyikun Derb

Libsework Abebaw

Mahlet Demssie

Mahlet Gashaw

Marta Madebo

Marta Yimam

Mastewal Kassahun

Me'aza Aberham
Mulunesh Mengstu

Negashe Negussa

Raheel Hailu

Rahel Yaregal

Ribka Yimer

Sahlitu Made Birhan

Samson Abdisa

Seble Hailu

Seid Mohammed

Selamawit Jemal

Semhar Tesfatsion

Senait Degefa

Senait Tadese

Senay Atsebeha

Sewunet Tadesse

Shewazewud Berhanu

Shewit G/Tsadik

Shibre Yadeta

Shiwaye Negewo

Simegn Siyum

Simegnaw Maru

Sisay Tsegaye

Solomon Gidey

Sultan jundi

Tamirat Endale

Tamiru Bekele

Tegbaru Batire

Teguade Mihretu

Tejitu Shiferaw

Teka Tareke

Tenanesh Wondimu

Tesfaye Degefu

Tesfaye Molla

Tibebu Tefera

Tigst Demelash

Tirsit Berhanu

Tiru Bekele

Tirukelem Mulu

Tisemialesh Mekonnen

Tisit Seyoum

Tsegamlak Endale

Tsehay Tadesse

Tsigereda Bayileyegn

Wolday G/Hiwot

Worku Meles

Wozam G/Medihn

Wubayehu Admas

Wubshet Oycha

Wudnesh Alemu

Yalemzerf Motayfir 


\begin{tabular}{|c|c|c|}
\hline Bereket Desta & Me'aza Haile & Yared Tefera \\
\hline Berhanu G/Meskel & Mekonnen Amare & Yayesh Desalegn \\
\hline Berhe Kunuye & Mekonnen Yami & Yekatit Tefera \\
\hline Betelhem Berhanu & Melat Tilahun & Yemata Asefa \\
\hline Birhane Assefa & Melkam Amsalu & Yemsrach Mulatu \\
\hline Birhanu Hirpa & Mengist Abdis & Yeshi Argeta \\
\hline Birkie Wubshet & Mengistu Chala & Yeshimebet Mengiste \\
\hline Birtukan Muluneh & Meresa Giday & Yeshiwork Haile \\
\hline Buzuna Negewo & Meron Dibekulu & Yeshmebet Mengistu \\
\hline Chala Tereta & Meseret Bihonegn & Yihenew Abebe \\
\hline Dasash Menge & Meseret Demlew & Yirgalem Biratu \\
\hline Dawit Daka & Meseret Getachew & Yirgalem Tesfaye \\
\hline Dawit Futra & Meseret Lema & Zahra Mohammed \\
\hline Debre Getachew & Mesfin Merkeb & Zelalem Beza \\
\hline Degu Girma & Mesmer Mekonnen & Zemenay Yigzaw \\
\hline Denkinesh Haile Gebrael & Mesrach Belachew & Zenebech Dibaba \\
\hline Derese Gobena & Mihret Arefayine & Zertihun Abebe \\
\hline Desalegn Bekele & Moges melese & Zertihun Degu \\
\hline Desta Gibore & Mohammed Jelan & Zewude Eniyew \\
\hline Emebet & Mohammed Mussa & Zewude Sertse \\
\hline Esmael Asefa & Mulu G/Michael & Zewuditu Alemayehu \\
\hline Estalu Belay & Mulualem Azimera & Zinash Gemechu \\
\hline Etaferahu Mega & Mulugeta G/Tsadik & Zufan Tesfaye \\
\hline Etenesh Mahammed & Mulunesh Megaro & \\
\hline
\end{tabular}





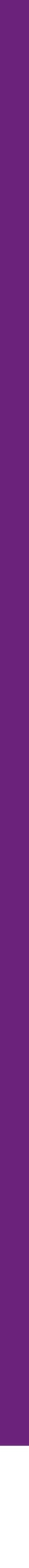

